\title{
Article
}

\section{The Executive Power over Foreign Affairs}

\author{
Saikrishna B. Prakash ${ }^{\dagger}$ and Michael D. Ramsey ${ }^{\dagger \dagger}$
}

\section{CONTENTS}

I. THE SHORTCOMINGS OF MODERN FOREIGN AFFAIRS

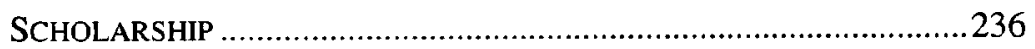
A. The Fruitless Search for the Supreme Branch
in Foreign Affairs.
B. The Failure To Explain Allocations of Specific
Foreign Affairs Powers ...........................................................243
1. The Unexplained Assumptions ..........................................2243

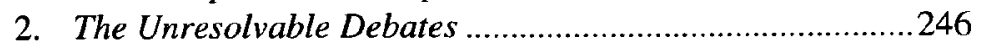

II. A COMPREHENSIVE TEXTUAL THEORY OF FOREIGN AFFAIRS ........252

A. Four Principles of Constitutional Foreign Affairs Powers ........252

B. A Textual Defense of the Four Principles of Foreign Affairs Powers.......................................................256

C. Allocating "Missing” Foreign Affairs Powers...........................262

III. The EXecutive Power IN Eighteenth-Century

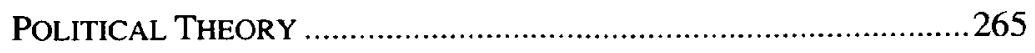

$\dagger$ Professor of Law, University of San Diego School of Law. E-mail: sprakash@acusd.edu.

$\dagger \dagger$ Professor of Law, University of San Diego School of Law. E-mail: mramsey@ acusd.edu.

Thanks to Larry Alexander, Akhil Amar, Curtis Bradley, Steve Calabresi, Jack Goldsmith, Nelson Lund, H. Jefferson Powell, Michael Rappaport, John Rogers, John Yoo, and participants in the University of San Diego School of Law faculty workshop for helpful comments. Thanks to William Jaynes for research assistance. 
IV. THE EXECUTIVE POWER OVER FOREIGN AFFAIRS OF THE CONTINENTAL CONGRESS

V. THE EXECUTIVE POWER OVER FOREIGN AFFAIRS AT THE PHILADELPHIA CONVENTION

VI. The EXecutive POWER OVER Foreign AfFaIRS IN THE RATIFICATION DEBATES

VII. The EXeCUTIVE POWER OVER Foreign AFFAIRS IN WASHINGTON'S ADMINISTRATION 295

A. The President's Control of the Instruments of Foreign Affairs 298

1. Washington Dominates the Old Department of Foreign Affairs 298

2. Congress Creates a New Executive Department of Foreign Affairs. 300

3. Congress Funds the Executive Department of State ............303

4. The Executive Seeks Advice on His Executive Power ..........305

5. The Chief Diplomat Controls His Department ......................307

6. Conclusion: The Chief Diplomat's Department ...................310

B. The President's Control over the Recognition of Governments and the Reception of Emissaries

1. Recognition of Foreign Governments and Emissaries .........312

2. Dislodging Foreign Emissaries ...........................................314

C. The President's Control over Communications...........................317

D. The President's Power To Terminate Treaties ...........................324

E. The President's Power To Establish Foreign Policy...................327

1. The Neutrality Proclamation as Evidence of the President's Power To Set Policy 328

2. The Scope of Washington's Neutrality Decision ..................332

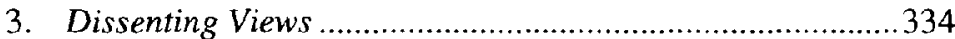

4. Postscript on the Nootka Sound Incident ...........................339

F. Presidential Lawmaking Power over Foreign Affairs ................340

G. Congressional Foreign Affairs Powers ...................................346

1. Independent Powers of Congress .............................................

2. Derivative Powers of Congress ............................................ 350

3. The Senate's Unique Role .....................................................353

H. Postscript to the Washington Administration ..............................354

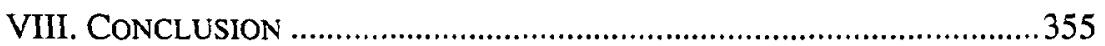

Imaged with the Permission of Yale Law Journal 
No foreign affairs scholar writes on a clean slate. Many eminent scholars and judges have labored to make sense of the Constitution's allocation of foreign affairs powers. Although these attempts often have little in common, they share one trait: They have given up on the Constitution. The received wisdom would have us believe that the foreign affairs Constitution contains enormous gaps that must be filled by reference to extratextual sources: practice, convenience, necessity, national security, international relations law and theory, inherent rights of sovereignty, and so forth. Yet reaching for these extratextual sources casts doubt on the entire enterprise, for one would think that the Constitution's text ought to play the preeminent role in discerning the Constitution's allocation of foreign affairs powers.

Perhaps due to the array of extratextual sources brought to bear, modern scholarship remains without a coherent and complete theory of the constitutional division of foreign affairs powers. First, there is no adequate explanation of the source and scope of the foreign affairs powers of the President. It is conventional wisdom that the President is, at minimum, the "sole organ" of communication with foreign nations and is empowered to direct and recall U.S. diplomats. Many scholars would go further, asserting that the President is the primary locus of foreign affairs power. Yet the President's enumerated powers do not seem to convey anything approaching even the minimum powers everyone assumes the President to enjoy. Second, there is no adequate explanation of the foreign affairs powers of Congress. Most scholars assume that Congress has a general power to legislate in foreign affairs matters, and many argue that Congress, rather than the President, should be the dominant decisionmaker. But the enumerated foreign affairs powers of Congress, while seemingly broader than the President's, also do not apparently encompass the full extent of the foreign affairs powers Congress is thought properly to exercise. Third, and most importantly, modern scholarship has achieved no consensus on even the most basic framework for resolving disputes over the allocation of particular foreign affairs powers not specifically mentioned in the Constitution's text. To pick a few examples, the power to terminate treaties, to enter into executive agreements, and to establish and enforce U.S. foreign policy are heatedly and inconclusively debated with no apparent hope of converging upon a common approach.

We need to wipe the foreign affairs slate clean and start over. In our view, modern scholarship should stop assuming that the Constitution's text says little about foreign affairs and stop treating foreign affairs powers as "up for grabs," to be resolved by hasty resort to extratextual sources. Outside the foreign affairs field, constitutional scholars agree that the text is the appropriate starting point. That should be true of foreign affairs scholarship as well. In this Article, we hope to show that the Constitution's 
text, properly construed, answers the supposedly perplexing foreign affairs questions posed above.

We argue that the text supplies four basic principles that provide a framework for resolving controversies over the source and allocation of foreign affairs powers.' First, and most importantly, the President enjoys a "residual" foreign affairs power under Article II, Section 1's grant of "the executive Power." 2 As we seek to establish in this Article, the ordinary eighteenth-century meaning of executive power - as reflected, for example, in the works of leading political writers known to the constitutional generation, such as Locke, Montesquieu, and Blackstone-included foreign affairs powers. By using a common phrase infused with that meaning, the Constitution establishes a presumption that the President will enjoy those foreign affairs powers that were traditionally part of the executive power. ${ }^{3}$

1. In our view, a textual theory of foreign affairs begins with the Constitution's text. In particular, it must be based upon a reading of actual words in the Constitution, not deduced from some broader theory of government (whether one's own or one purportedly held by the Framers). It does not, however, end with the text. Words have no meaning in a vacuum, shorn of their context. To discern that context, one must look outside the text. Indeed, even when legal texts contain definitions, the definitions themselves are composed of words that must be understood by reference to meanings "external" to the text. Not surprisingly, our textual theory is not just an extended citation to the Constitution's text. Further, we think the appropriate context from which to discern the meaning of the words in a legal document is the context in which they were written. Hence, our goal is to try to make sense of the Constitution's text as it would have been understood in the Founding era. Finally, we think the best evidence of the meaning of a text is to see how intelligent and engaged people at the time it was written commonly understood the words it employs. Accordingly, in seeking a textual theory of constitutional foreign affairs power, we look first to the actual words of the Constitution-specifically, to the grant of "the executive Power" in Article Il, Section 1. But to understand the meaning of the phrase "the executive Power," we must look to its context, and in particular to the way those words were commonly used. Hence the bulk of our discussion is directed toward establishing an eighteenth-century meaning of executive power.

2. We are not the first to identify Article II's vesting of executive power as a source of substantive presidential powers. Others have argued that the executive power is quintessentially about the power to execute the law. Steven G. Calabresi \& Saikrishna B. Prakash, The President's Power To Execute the Laws, 104 YALE L.J. 541 (1994); Saikrishna Prakash, The Essential Meaning of Executive Power, 2002 U. ILL. L. REV. (forthcoming). Nothing we say here is inconsistent with the notion that the executive power primarily refers to the power to execute the laws. We argue here that evidence from the Founding era also reveals that executive power had a secondary, foreign affairs meaning.

3. The proposition that "the executive Power" of Article II, Section 1 is the source of "unenumerated" foreign affairs powers has been suggested but never subjected to comprehensive academic study. For the most part, it has been mentioned only in the context of denying that this could be a viable source of foreign affairs power. See, e.g., Gerhard CASPER, SeParating POWER 68 (1997) (denying that the grant of executive power includes foreign affairs power); EDWARD S. CORWIN, THE PRESIDENT 1787-1984, at 177 (Randall Bland et al. eds., 5th ed. 1984) (same); HaRold HonguU KOH, The National SECURITY CONSTITUTION 75 (1990) (same); Bruce Stein, Note, Notes on Presidential Foreign Policy Powers: The Framers' Intent and the Early Years of the Republic, 11 HOFSTRA L. REV. 413, 511 (1982) (same). Even some advocates of strong presidential power downplay Article II, Section I as a textual source. See, e.g., H. Jefferson Powell, The President's Authority over Foreign Affairs: An Executive Branch Perspective, 67 GEO. WASH. L. REV. 527, 535 (1999). Various scholars, including one of the present authors, have suggested Article II, Section 1 as a logical solution to the supposed "lacunae" of foreign affairs power without making a complete case for that interpretation. See 
Second, the President's executive power over foreign affairs is limited by specific allocations of foreign affairs power to other entities-such as the allocation of the power to declare war to Congress. Thus, the President has a circumscribed version of the traditional executive power over foreign affairs. Notwithstanding the common understanding of executive power, the President cannot regulate international commerce or grant letters of marque and reprisal. Third, Congress, in addition to its specific foreign affairs powers, has a derivative power to legislate in support of the President's executive power over foreign affairs and its own foreign affairs powers. But contrary to the conventional view, Congress does not have a general and independent authority over all foreign affairs matters. In particular, Congress cannot establish relations with a foreign country or establish foreign policy. Fourth, the President's executive power over foreign affairs does not extend to matters that were not part of the traditional executive power, even where they touch upon foreign affairs. In particular, the President cannot claim power over appropriations and lawmaking, even in the foreign affairs arena, by virtue of the executive power. That is to say, the President is not a lawmaker, even in foreign affairs.

Below we begin the task of wiping the foreign affairs slate clean and writing anew. Part I highlights the difficulties of modern foreign affairs scholarship, including its repeated denial that the Constitution's text can provide much meaningful guidance in allocating foreign affairs powers. Part II details the four fundamental principles that we derive from the Constitution's text and that provide a comprehensive framework for addressing foreign affairs disputes. This Part further illustrates how these principles are consistent with the Constitution's text read as a whole and how they provide guidance in the resolution of key dilemmas of foreign affairs law. Part III begins the task of establishing the common eighteenthcentury understanding of executive power by discussing the usage of that phrase in eighteenth-century political thought. In this Part we show that eighteenth-century political theory included foreign affairs powers as part of the executive power, thus providing a firm foundation for our reading of Article II, Section 1.

Robert F. TURner, RePEALING THE WAR POWFrs ReSOlution 52-80 (1991) (suggesting a broad reading of Article II, Section 1); Charles Cooper et al., What the Constitution Means by Executive Power, 43 U. MIAMI L. REV. 165 (1988) (same); Michael D. Ramsey, Executive Agreements and the (Non)Treaty Power, 77 N.C. L. REv. 133, 206-10 (1998) (suggesting Article II, Section 1 as the textual basis of the President's power to enter into executive agreements); John C. Yoo, The Continuation of Politics by Other Means: The Original Understanding of War Powers, 84 CAL. L. REV. 167, 196-217 (1996) (describing the eighteenth-century reading of "executive power" as including war power). Something of this sort was also proposed by William Crosskey, although in the broader context of a reading of the Constitution with which we fundamentally disagree. See 1 WiLliam CROSSKEY, POLITICS AND THE CONSTITUTION IN THE HISTORY OF THE UNITED STATES 416 (1953). 
In Part IV we discuss foreign affairs powers under the Articles of Confederation, illustrating first that the Continental Congress's exercise of foreign affairs powers was commonly called "executive" power, and second that serious practical problems arose from a multimember body's exercise of the executive foreign affairs powers. In Part $\mathrm{V}$ we consider the Philadelphia Convention, in which delegates shifted portions of the executive power of the Continental Congress to a single President. We show how both background understandings of the phrase "executive power" and specific discussion by the delegates confirm a reading of executive power to include foreign affairs powers. We also show how dissatisfaction with the breadth of the traditional executive power over foreign affairs led the delegates to allocate certain foreign affairs powers elsewhere, laying the foundation for our interpretation of these allocations as exceptions carved out of the President's executive power. Part VI addresses the ratifying conventions, and shows that their discussions of foreign affairs are consistent with our view of unallocated foreign affairs powers as presidential executive powers. Finally, Part VII examines the Washington Administration and finds a usage and practice that closely conform to our theory of executive power over foreign affairs.

Our framework reveals that there are no gaps in the Constitution's allocation of foreign affairs powers. The Constitution's text supplies a sound, comprehensive framework of foreign affairs powers without appeal to amorphous and disputed extratextual sources. Moreover, there is substantial evidence that this textual framework is the correct interpretation of the Constitution, as it comports with usage and practice before, during, and after the Constitution's ratification. Finally, other theories or frameworks have a rather difficult time of accounting for the evidence supporting our framework. To slight the foreign affairs meaning of executive power is to downplay Locke, Montesquieu, Blackstone, Washington, Jay, Jefferson, Hamilton, and even Madison.

\section{THE SHORTCOMINGS OF MODERN FOREIGN AFFAIRS SCHOLARSHIP}

Modern discussion of the Constitution's allocation of foreign affairs powers suffers from two acute embarrassments. First, beyond the powers to declare war and enter into treaties, the discourse largely ignores the Constitution's text. ${ }^{4}$ A common tenet of scholars who agree on little else is

4. With respect to war and treaty power, much recent scholarship considers the Constitution's text and original meaning. See, e.g., JOHN HART ELY, WAR AND RESPONSIBILITY (1993); LOUIS FISHER, PRESIDENTIAL WAR POWER (1995); Carlos Manuel Vázquez, Laughing at Treaties, 99 Colum. L. REV. 2154 (1999); Yoo, supra note 3; John C. Yoo, Treaties and Public Lawmaking: A Textual and Structural Defense of Non-Self-Execution, 99 COLUM. L. REV. 2218 (1999). We 
that once one moves beyond the war and treaty-making powers, the Constitution itself has little to say about the relative roles of the President and Congress, but rather contains substantial gaps that compel resort to other considerations. Accordingly, a host of nontextual factors-practice, convenience, necessity, national security concerns, international relations theory, international law, inherent rights of sovereignty, and so forthdrives "constitutional" scholarship in this area.

Second, modern foreign affairs scholarship has failed to provide a satisfactory account of the source and allocation of presidential and congressional foreign affairs powers. Scholars heatedly and inconclusively debate whether the President or Congress should have the supreme role in foreign affairs, and have sharp and seemingly insoluble disagreements over the allocation of particular foreign affairs powers, such as the power to terminate treaties, the power to set foreign policy, and the power to enter into executive agreements. Each branch has its able academic advocates, but there seems little prospect of resolution, or even agreement upon what the relevant considerations should be. And even when foreign affairs scholars agree upon an appropriate allocation in a particular area, they cannot explain why the conventional allocation is the correct one. Most everyone agrees, for example, that the President speaks for the United States in the international sphere and can instruct and recall ambassadors, and most agree that Congress can legislate with respect to a wide range of foreign affairs and national security matters. Yet there is little attempt to explain how these allocations cohere with the Constitution's text or to construct from these allocations a comprehensive theory of foreign affairs powers. ${ }^{5}$

The second difficulty is closely related to the first. Foreign affairs scholars have too quickly assumed that the Constitution's text does not adequately allocate foreign affairs powers. By discarding the textual moorings of constitutional law, however, they have been left adrift with no satisfactory guide in resolving these matters. A few examples illustrate why modern foreign affairs scholarship is lost.

\section{A. The Fruitless Search for the Supreme Branch in Foreign Affairs}

Judges, practitioners, and foreign affairs scholars have long debated whether the President or Congress should primarily direct U.S. foreign

therefore largely exclude these powers from our consideration and address ourselves instead to matters conventionally believed to be beyond the constitutional text.

5. See Louis Henkin, Foreign AfFaIRS AND THE U.S. CONSTITUTION 14-15 (2d ed. 1996) (providing a representative list of "missing" powers and adding that these powers "and a host of others were clearly intended for, and have always been exercised by, the federal government, but where does the Constitution say that it shall be so?"). 
affairs. Commentators essentially divide into three camps: those who think that foreign affairs should be largely controlled by the President, those who see Congress as the dominant power in foreign affairs, and those who find no satisfactory allocation of foreign affairs powers. But these camps have not articulated a complete or convincing theory, nor one soundly based on the Constitution's text.

The first view, sometimes labeled "presidential primacy," holds that "[t]he President has primary responsibility for the conduct of the foreign affairs of the United States," and although Congress has some specific powers that "concern or bear upon foreign affairs[,] ... the presidency is the institution on which the Constitution places the duty to look to the Republic's interests in the international arena." ${ }^{6}$ The practice of the last century ${ }^{7}$ and an array of judicial opinions ${ }^{8}$ support the idea of presidential primacy. As a matter of constitutional interpretation, however, the presidential primacy theory is fatally incomplete, for it lacks a textual basis. Even if one broadly construed the President's foreign affairs powers in Article II, Sections 2 and 3, they would not yield a comprehensive mandate, ${ }^{9}$ and advocates of presidential supremacy have identified no other textual basis for their claim. ${ }^{10}$

As a result, the claim of presidential primacy in foreign affairs lies beyond constitutional text, and indeed often beyond constitutional law entirely. Perhaps most notoriously, the Supreme Court's Curtiss-Wright decision" asserted "the very delicate, plenary and exclusive power of the President as the sole organ of the federal government in the field of international relations-a power which does not require as a basis for its exercise an act of Congress." ${ }^{12}$ Curtiss-Wright has been criticized on many

6. Powell, supra note 3, at 545-46.

7. KOH, supra note 3 (describing and criticizing the extent of modern presidential power over foreign affairs); David Gray Adler, Court, Constitution, and Foreign Affairs, in THE CONSTITUTION AND THE CONDUCT OF AMERICAN FOREIGN POLICY 19, 19 (David Gray Adler \& Larry N. George eds., 1996) (noting "[t]he unmistakable trend toward executive domination of U.S. foreign affairs in the past sixty years").

8. H. Jefferson Powell, The Founders and the President's Authority over Foreign Affairs, 40 WM. \& MARY L. REV. 147I, 1473 n.7 (1999) (collecting cases).

9. The President's specifically enumerated powers are to receive ambassadors and to act as Commander in Chief of the military, plus a shared power to make treaties and ambassadorial appointments. U.S. CONST. art. II, \&\$ 2, 3. We are not aware of any comprehensive academic study purporting to show that these can be stretched to cover all, or even most, of the powers commonly assumed to lie with the President, and we do not think such a claim could be supported.

10. Professor Powell, for example, concedes "the impossibility of resolving many issues involving foreign affairs and the defense of the Republic through textual excgesis." Powell, supra note 3 , at 535 .

11. United States v. Curtiss-Wright Export Corp., 299 U.S. 304 (1936).

12. Id. at 320. On the influence of Curriss-Wright, David Gray Adler observes:

There can be little doubt that the opinion ... has been the Court's principal contribution to the growth of executive power in foreign affairs .... Even when the sole-organ doctrine has not been invoked by name, its spirit, indeed its talismanic aura, has 
grounds, ${ }^{13}$ but whatever its other demerits, it simply does not approach the matter as a constitutional question. Justice Sutherland, writing for the Court, argued that "the investment of the federal government with the powers of external sovereignty [i.e., foreign affairs] did not depend upon the affirmative grants of the Constitution." 14 Instead, these powers are and were "vested in the federal government as necessary concomitants of nationality" and, accordingly, authority for exercise of such powers is found "not in the provisions of the Constitution, but in the law of nations." Is Sutherland went on to claim that these extraconstitutional powers lay with the President—that "[i]n this vast external realm ... the President alone has the power to speak or listen as a representative of the nation" - not on the basis of anything in the Constitution but as a matter of history, necessity, and convenience. ${ }^{16}$ In short, Curtiss-Wright posits that the Constitution does not grant many foreign affairs powers, that a complete picture of foreign affairs law must arise from other sources, and that these sources dictate presidential control. ${ }^{17}$

Professor Jefferson Powell's recent attempt to construct a constitutional alternative to Curtiss-Wright illustrates the difficulties facing advocates of presidential primacy. ${ }^{18}$ Professor Powell properly rejects Curtiss-Wright and seeks to establish that the Constitution (not some extraconstitutional

provided a common thread in a pattern of cases that has exalted presidential power above constitutional norms.

Adler, supra note 7, at 25. According to Professor Harold Koh, "[a]mong government attomeys, Justice Sutherland's lavish description of the president's powers is so often quoted that it has come to be known as the "“Curtiss-Wright so I'm right" cite." КОH, supra note 3, at 94.

13. See, e.g., Michael J. Glennon, Constitutional Diplomacy 18-34 (1990); KoH, supra note 3, at 93-95; Jack L. Goldsmith, Federal Courts, Foreign Affairs and Federalism, 83 VA. L. REV: 1617, 1659 (1997); Michael D. Ramsey, The Myth of Extraconstitutional Foreign Affairs Power, 42 WM. \& MARY L. REV. 379 (2000).

14. Curtiss-Wright, 299 U.S. at 318. But see U.S. CONST. amend. X ("The powers not delegated to the United States by the Constitution, nor prohibited by it to the States, are reserved to the States respectively, or to the people.").

15. Curtiss-Wright, 299 U.S. at 318.

16. Id. at 319 ; see id. at $318-20$ (emphasizing the President's superior ability to conduct foreign affairs).

17. In Professor Koh's words, Curtiss-Wright's theory was that "the president 'possesses a secret reservoir of unaccountable power' that flows from external sovereignty and not the constitution." KOH, supra note 3, at 95 . Scholarly defenses of presidential power often have much in common with Curtiss-Wright. Professor Eugene Rostow, for example, argues that:

In the field of international relations, the Government of the United States has all the rights, powers, privileges, immunities and duties of nationhood or 'sovereignty' recognized in international law. The international powers of the nation are not to bc deduced from the few spare words of the constitutional text, but from their matrix in international law.

Eugene V. Rostow, President, Prime Minister, or Constitutional Monarch?, in ForeIGN AFFaIRS AND THE U.S. CONSTITUTION 29, 30-31 (Louis Henkin et al. eds., 1990). Since Congress has only enumerated powers, Professor Rostow continues, the remaining powers must be the President's. Id.

18. See Powell, supra note 3; Powell, supra note 8. 
notion of sovereignty) creates a presidential foreign affairs mandate. ${ }^{19}$ But he ultimately finds the text not up to the task:

$[\mathrm{N}] \mathrm{o}$ provision of the Constitution vests either the President or Congress with a general power over foreign affairs or national security. Instead, the constitutional text enumerates a variety of powers bearing on these areas that it delegates to one or the other political branch without specifying how the enumerated powers are to be related to one another or organized into a coherent framework of governance and responsibility. ${ }^{20}$

Thus, "the arguments for the President's authority over foreign affairs rest largely on structural inference" ${ }^{21}$ and "the principle that the President is the constitutional representative of the people and the Republic in foreign affairs" is "inferred from the President's enumerated powers and from the goals and functions of the federal government in the area of foreign affairs." 22 Those dubious of presidential primacy may wonder whether Powell's "structural inference" is any better than Curtiss-Wright's invocation of "external sovereignty." 23

The apparent dearth of textual presidential powers over foreign affairs leads a second group of scholars to the opposite conclusion: Congress, not the President, should primarily control foreign affairs. John Hart Ely observes, for example, that "[t]he Constitution gives the president no general right to make foreign policy. Quite the contrary.... [V]irtually every substantive constitutional power touching on foreign affairs is vested in Congress." ${ }^{24}$ Although advocates of congressional primacy inexplicably accord the President the power to communicate with foreign powers, ${ }^{25}$ they contend that "Articles I and II of the Constitution reveal the intent of the framers to give Congress the dominant hand in the establishment of basic

\footnotetext{
19. Powell, supra note 3 , at $542 \mathrm{n} .74,546$.

20. Id at 545 .

21. Id. at 535 .

22. Id at 548 .

23. We view Professor Powell's work as presenting the best constitutional argument among defenders of presidential primacy, and we might not differ as to results on the allocations of many specific powers. But we are troubled by his rejection of a textual basis for his view. Although we have no systematic objection to arguments based on structural inferences, when something as significant as foreign affairs is at stake, we doubt that the Constitution's text leaves so much to debatable inferences.

24. JOHN HART ELY, ON CONSTITUTIONAL GROUND 149 (1996).

25. KOH, supra note 3, at 94-95 (referring to the Framers' understanding of " a narrowly limited realm of exclusive presidential power in foreign affairs. The president's exclusive realm embraced his textually enumerated powers and his ... mastery of our diplomatic communications with the outside world"); David Gray Adler, Introduction to THE CONSTITUTION AND THE CONDUCT OF AMERICAN FOREIGN POLICY, supra note 7, at 1, 3 (referring to the "Framers' studied decision to vest the bulk of foreign policy powers in Congress" and emphasizing that the President has only two enumerated foreign affairs powers: power as Commander in Chief and power to receive ambassadors).
} 
policy regarding foreign relations" ${ }^{26}$ and that the Framers "simply did not intend the President to be an independent and dominating force, let alone the domineering one, in the making of foreign policy." 27

Recognizing an easy target when they see it, advocates of congressional primacy have argued at length that Curtiss-Wright's allocation of foreign affairs control to the President is incoherent, ahistorical, and indefensible. ${ }^{28}$ But overshadowing their attacks is an equally intractable problem: What is the source of Congress's supposed primacy in foreign affairs? Nothing in Article I generally addresses foreign affairs. Rather, Congress enjoys only certain specific foreign affairs powers outlined in Article I, Section $8 .^{29}$ Perhaps for this reason, no comprehensive theory based on anything actually in the Constitution's text has been put forward to explain Congress's asserted primacy in foreign affairs. Instead, advocates of congressional primacy agree with their pro-presidential adversaries: The answers cannot be found in the Constitution's text. Professor Harold Koh, for example, acknowledges that although the Constitution vests a few specific powers, "[m]ost often, the text simply says nothing about who controls certain domains." ${ }^{30}$ As a result, he invites us to "look beyond the Constitution's cryptic text to discover the broader constitutional principles that govern how Congress, the courts, and the executive should interact in the foreign policy process." ${ }^{31}$ Apparently, although "the Constitution's drafters assigned Congress the dominant role in foreign affairs," ${ }^{32}$ they neglected to codify their fundamental decision. ${ }^{33}$

26. Francis D. WORMUTH \& EDWIN B. Firmage, To CHAIN THE DOG OF WAR 177 (1986); see also Powell, supra note 8, at 1471-74 nn.1-9 (collecting additional authorities taking what he calls the "congressional-supremacy" view); Stein, supra note 3, at 511 (arguing for a "dominant congressional role in foreign policy"); Phillip R. Trimble, The President's Foreign Affairs Power, in FOREIGN AFFAIRS AND THE U.S. CONSTITUTION, supra note 17, at 39, 40 ("Congress has virtually plenary authority over all aspects of foreign policy.").

27. LeONARd W. LeVy, ORIGINAL INTENT ANd THE Framers' Constitution 30 (1988).

28. E.g., GlennON, supra note 13 , at 18-34; $\mathrm{KOH}$, supra note 3, at 93-98.

29. U.S. CONST. art. I, $\$ 8$.

30. $\mathrm{KOH}$, supra note 3, at 67 (admitting "astonishing brevity regarding the allocation of foreign affairs authority").

31. Id. at 68. In observations closely paralleling Professor Powell's, Professor Koh assents that foreign policy questions frequently must be resolved not by "textual exegesis" but from a "normative vision of the foreign-policy-making process" that "lurks within our constitutional system." Id.; cf. Powell, supra note 3, at 534-35 (asserting the "impossibility of resolving many issues involving foreign affairs ... through textual exegesis" and instead endorsing arguments, such as those of Charles Black, based upon " "claims that a particular principle or practical result is implicit in the structures of government"”). Professors Koh and Powell reach exactly opposite conclusions on the merits, undermining confidence in one's ability to discern what "lurks within our constitutional system."

32. КОH, supra note 3 , at 79.

33. Professor Koh goes on to conclude that the modern distribution of foreign affairs powers represents presidential usurpation of congressional power, a theme common to other prominent writers taking the congressional primacy perspective. Id. at 79-81; see, e.g., Adler, supra note 7, at 19-21 (asserting that "[t]he constitutional blueprint assigns to Congress senior status in a partnership with the president for the purpose of conducting foreign policy" primarily on the 
A third group of scholars also sees the Constitution as flawed and incomplete in foreign affairs, but refrains from declaring that either branch is preeminent. The Constitution, Edward Corwin famously wrote, "is an invitation to struggle for the privilege of directing American foreign policy." ${ }^{34}$ In Professor Corwin's view, those asserting presidential preeminence "would be hard put" to cite any "definite statement to this effect in the Constitution itself." 35 But Professor Corwin also understood that Congress lacked a broad grant of foreign affairs power. Rather, he said, "all that [the Constitution] does" is vest certain authorities with the President, others with the Senate, and still others with Congress, while leaving yet others entirely unresolved ${ }^{36}$ In his view, both the President and Congress have repeatedly asserted powers that cannot be traced to any constitutional source, confirming that the federal government enjoys inherent (and unallocated) power over foreign affairs. ${ }^{37}$ More recently, Louis Henkin, in his foundational work on the constitutional law of foreign affairs, emphasized the gaps left by the Framers. The Constitution in foreign affairs, he says, "seems a strange, laconic document" with "troubl[ing] .. . lacunae" in which "many powers of government are not mentioned." ${ }^{8}$ Ultimately, in his view, "[a]ttempts to build all the foreign affairs powers of the federal government with the few bricks provided by the Constitution have not been widely accepted." 39 As a result, the constitutional text itself hardly figures in his approach to key foreign affairs challenges: "I am disposed to state the question," he writes, "as: How should foreign affairs be run in a republic that has become a democracy?" 40

In short, modern foreign affairs scholarship strenuously debates which branch is supreme in foreign affairs, but the participants in this debate have

ground that "there was no hint at the Constitutional Convention of an exclusive presidential power to make foreign policy"). In fairness to Professor Koh, we regard his book as primarily a critique of the Reagan Administration's conduct of foreign affairs. Although he refers to the Framers and briefly examines the Washington Administration, his true target is the Iran-Contra affair.

34. CoRWIN, supra note 3, at 201.

35. Id.

36. Id. (emphasis omitted).

37. Id. at 202.

38. HENKIN, supra note 5, at 13-14.

39. Id. at 15. Professor Henkin argues:

The general reader might comb the Constitution yet find little to support the legitimacy of large Presidential claims. The powers explicitly vested in him are few and appear modest, far fewer and more modest that those bestowed upon Congress. What the Constitution says and does not say, then, can not have determined what the President can and can not do. The structure of the federal government, the facts of national life, the realities and exigencies of international relations (particularly in the age of nuclear weapons and during the Cold War and its aftermath), and the practices of diplomacy, have afforded Presidents unique temptations and unique oppontunities to acquire unique and ever larger powers.

Id. at 31 (citations omitted).

40. Louis Henkin, Foreign Affairs and the Constitution, 66 FOREIGN AFF. 284, 307 (1987). 
abandoned the Constitution's text as an authoritative source. We are told instead to look to, among other things, "the goals and functions of the federal government in the area of foreign affairs," 41 the "facts of national life, the realities and exigencies of international relations," 42 the "inherent[] . . . conception of nationality," ${ }^{43}$ and, ultimately, "what kind of country we are and wish to be." 44

\section{B. The Failure To Explain Allocations of Specific Foreign Affairs Powers}

The debate fares no better when it moves from the generalized question of "supremacy" or "primacy" in foreign affairs to allocations of specific foreign affairs powers. Much of modern scholarship-from whichever of the foregoing camps-agrees upon certain "obvious" allocations of power: The President is the organ of communication with foreign governments and exercises authority over U.S. and foreign diplomats, and Congress legislates with respect to international matters. But modern scholars cannot explain the textual basis for these assumptions. Beyond this limited consensus, scholars fiercely debate the allocation of key foreign affairs powers, but again they cite no textual authority for their positions.

\section{The Unexplained Assumptions}

Even the most committed advocate of congressional primacy usually admits that the President is the "sole organ of official communication" in foreign affairs. ${ }^{45}$ Indeed, many scholars argue that the President is only a spokesperson, with only the few limited substantive powers set forth in Article II, Sections 2 and $3 .^{46}$ But how do they know the President speaks for the United States? If the Constitution says little about substantive presidential power over foreign affairs, it also says little about the President's supposed role as international spokesperson. If the President can claim only the powers of Article II, Sections 2 and 3, much of the

41. Powell, supra note 3 , at 548.

42. HENKIN, supra note 5 , at 31 .

43. United States v. Curtiss-Wright Export Corp., 299 U.S. 304, 318 (1936).

44. Henkin, supra note 40 , at 307.

45. HENKIN, supra note 5, at 42 ("That the President is the sole organ of official communication by and to the United States has not been questioned and has not been a source of significant controversy.").

46. See, e.g., id. at $42-43$ ("Issues begin to burgeon when the President claims authority, as 'sole organ,' to be more than an organ of communication and to determine also the content of the communication, or when, under his 'foreign affairs power,' the President presumes to determine also the attitudes, decisions, and actions which are the foreign policy of the United States."); KOH, supra note 3, at 95; Adler, supra note 7, at 21; see also GLENNON, supra note 13, at 24 (suggesting that the President is limited to a communicative function). 
President's role as sole communicative organ seems inexplicable. ${ }^{47}$ Yet if the communicative role is found (by implication or some other means), why not also find further powers? We are not aware of anyone who has addressed this serious difficulty. ${ }^{48}$

On the other hand, advocates of presidential primacy generally assume the President has the role of spokesperson, and use this common ground as a foundation for implying even greater presidential foreign affairs powers. But their theory can be no stronger than its foundation, and they have not built their foundation on anything in the Constitution's text. ${ }^{49}$ In sum, no one on either side of the debate can explain textually what everyone assumes: that the President is the sole organ of communication in external affairs.

To take another issue, most everyone supposes that the President has the power to recall U.S. ambassadors. ${ }^{50}$ This power has been exercised without question, even with respect to controversial ambassadors in times of political partisanship..$^{51}$ But what is the source of the President's power? The only remotely relevant provision in Article II, Sections 2 and 3 is the President's power, with the consent of the Senate, to appoint ambassadors $^{52}$ - which surely cannot convey to the President alone the power to recall them. One might argue that ambassadors are analogous to executive officers, who are appointed by the President with the consent of the Senate but can be removed by the President alone; on this theory, ambassadors also could be removed (recalled) by the President alone. But this assumes the President has plenary authority over ambassadors comparable to the President's authority over executive officers, and that is not at all obvious from the text. Because the President is constitutionally charged with enforcing the laws, the President has an evident constitutional source of power over executive officers who assist in the enforcement of

47. The President's explicit power to appoint ambassadors is shared with the Senate, and although the President has an explicit power to receive ambassadors that could be construed to contain some communicative authority, not all, or even most, communication occurs through foreign ambassadors.

48. Supporters of congressional supremacy may argue that the President, as the Chief Executive, can communicate as a means of carrying out Congress's foreign affairs laws, since even a limited reading of the President's power would include the power to carry out ("execute") the laws. But this solution only postpones the intractable question: If the President derives power from Congress, where in the Constitution is Congress's general power to pass foreign affairs laws? As with the President, the text's specific grants of power to Congress do not add up to a general foreign relations authority.

49. See, e.g., Powell, supra note 3, at 548 (deriving the principle "that the President is the constitutional representative of the people and the Republic in foreign affairs" from, among other things, "the goals and functions of the federal government" and "pragmatic considerations about the executive's superior capacity for actually carrying out the tasks of foreign policy").

50. HENKIN, supra note 5, at 42.

51. E.g., infra Subsection VII.A.5 (discussing Washington's recall of James Monroe as ambassador to France).

52. U.S. CONST. art. II, $\$ 2$, cl. 2. 
the laws. Of course, one similarly could argue that because the President is ultimately in charge of foreign affairs (or at least in charge of communicating foreign policy) and ambassadors are involved in foreign affairs (or at least in voicing foreign policy), the President has power over them. But this argument assumes a point not yet demonstrated: that the President controls foreign affairs, or at least is empowered to communicate foreign policy. As indicated, in modern foreign affairs scholarship the latter point is assumed while the former is vigorously disputed. As a result, the President's supposed power to recall ambassadors remains without textual foundation.

Congress's power over foreign affairs similarly suffers from assumptions unsubstantiated by text. The conventional view is that Congress has broad power to legislate with respect to foreign affairs and national security matters, although (perhaps) limited by the President's foreign affairs powers. But just as Article II, Sections 2 and 3 do not appear to give the President a general foreign affairs power, Article I, Section 8 does not grant Congress such a power. To pick an example from early constitutional history, in 1799 Congress passed the Logan Act, prohibiting private parties from communicating with foreign governments on behalf of the United States. ${ }^{53}$ But where is Congress's enumerated power to do this? Lacking a general foreign affairs power, Congress would have had to rely on one of its specific powers, yet none seems sufficient. Modern foreign affairs scholarship simply cannot resolve this and similar questions in a satisfactory manner. Professor Henkin, for example, feels compelled to invent an extra-constitutional "Foreign Affairs Power" of Congress to defend that body's foreign affairs activities-a power that he says is "inherent" in the "sovereignty and nationhood" of the United States and is unencumbered by any need to locate it within Congress's enumerated powers. ${ }^{54}$

53. Logan Act, ch. 1, 1 Stat. 613 (1799).

54. As Professor Henkin summarizes:

Congress derives additional legislative authority from the powers of the United States inherent in its sovereignty and nationhood....

It is this "Foreign Affairs Power", presumably, that supports legislation regulating and protecting foreign diplomatic activities in the United States, providing for cooperation with foreign governments, c.g., by giving facilities to foreign consuls; or imposing restrictions on foreign governments.... [T]he Foreign Affairs Power might best support Congressional assertions of U.S. national sovereignty in territory or in air-space, and special authority in special zones at sea.

HENKIN, supra note 5, at 70. Indeed, "the Foreign Affairs Power would support legislation on any matter so related to foreign affairs that the United States might deal with it by treaty." $I d$. at 71 . 


\section{The Unresolvable Debates}

While some allocations of foreign affairs power are comfortably assumed in modern scholarship, others are heatedly debated. But again, few scholars make arguments based on the Constitution's text. Rather, most everyone assumes that the Constitution's text does not directly speak to these debated matters. The result is essentially a series of policy debates that shows no sign of satisfactory resolution.

Consider the determination of the content of the United States's international communications. As noted, it is widely agreed that the President is the organ of communication in foreign affairs (although the constitutional basis of this power remains obscure). Who, however, determines the substance of the communications? This inquiry is critical when the President is stating the policy position of the United States on a particular international matter, that is, whether the United States wishes to pursue a particular goal or support a particular position. This power has long been one exercised by the President-reflected, for example, in President Monroe's 1823 Doctrine (that the United States was opposed to any attempts by European powers to interfere with the independence of the new South American republics) and President Washington's 1793 declaration of neutrality in the Anglo-French war. ${ }^{55}$ But modern scholarship is closely divided on whether the power to formulate "foreign policy" in this sense is appropriately presidential, and neither side has a convincing explanation of its view. ${ }^{56}$

Advocates of presidential primacy find these policy determinations appropriate. In Professor Powell's view:

Although Congress through legislation, and the President and Senate through treaty-making, may enunciate foreign policy goals and influence foreign policy decisions, it is the President who, as a general matter, is vested with the authority to determine the policies

55. See 41 AnNals of Cong. 22-23 (1823) (statement of President James Monroe); infra Section VII.E (discussing Washington's Neutrality Proclamation).

56. In referring to a power over "foreign policy," we use that term narrowly to refer to, as one of us has previously put it, the power to determine "the U.S. opinion on international matters" and to "announce publicly the views of the United States (and thus direct the moral and diplomatic force of the United States) with respect to important international issues." Ramsey, supra note 3, at $210-11 \mathrm{n} .312$. In our usage, foreign "policy" is much the same as domestic "policy": a statement of opinion or aspiration not backed by legal force. We do not mean to use "foreign policy" loosely, as it sometimes is, to describe all U.S. relations with foreign nations. In particular, we exclude from "foreign policy" the power to make law relating to foreign affairs. It is simply the power to determine the content of the United States's statements about international relations. 
and objectives that the United States should pursue in its international relations. ${ }^{57}$

But where exactly did Washington and Monroe get their policymaking power? In neither case was it based on any act of Congress, nor is there a relevant power in Article II, Sections 2 or $3{ }^{58}$ Professor Powell argues that such power does not "rest[] on any particular clause of Article II" but instead upon "a complex mixture of textual arguments, ... structural arguments... [, and] on pragmatic considerations about the executive's superior capacity for actually carrying out the tasks of foreign policy." 59

Supporters of the congressional primacy view would, as a general matter, deny the President's power to set the substance of foreign policy, pointing to the (admitted) lack of enumerated powers and to their own set of "pragmatic considerations." ${ }^{60}$ Their view, naturally, is that the President should seek congressional approval of the substance of international communications. ${ }^{61}$ But, for example, under what Article I power could Congress authorize or promulgate the Monroe Doctrine? That announcement did not directly relate to any of Congress's powers, and Congress could act in support of the President (under Article I, Section 8, Clause 18) only if the President already had an independent constitutional power to announce foreign policy. ${ }^{62}$ Congressional advocates cannot explain this point without reaching for an unenumerated or wholly extraconstitutional power. ${ }^{63}$

57. Powell, supra note 3, at 549 .

58. With respect to the Monroe Doctrine, to pass a few obvious constitutional candidates, the doctrine was not announced to foreign ambassadors nor by U.S. ambassadors, nor in the course of negotiations toward a treaty, nor in connection with military action, commerce, or international law.

59. Powell, supra note 3 , at $547-48$.

60. See sources cited supra notes 24-28. Professor Koh, for one, characterizes Washington's neutrality policy as a usurpation. See $\mathrm{KOH}$, supra note 3, at 78-79; see also Adler, supra note 7, at 25 (taking a similar view).

61. See GLENNON, supra note 13, at 24 (distinguishing between the power to communicate, resting with the President, and the power to determine the content of the communication, resting with Congress).

62. See Ramsey, supra note 3, at 210-12. As discussed below, Congress's authority to authorize or promulgate Washington's Neutrality Proclamation might be covered by a stretch of either the war power or the power to define and punish offenses against the law of nations, although neither seems exactly on point. See infra Part VII.

63. A similar though less prominent example is the authority to issue and revoke passports. It surely seems that the federal government should have this power (although it is not inconceivable that it was left only with the states, as states did issue passports until that practice was prohibited in 1856). One might suppose that the passport power lies with the President, in accordance with practice early in the nation's history. See Galliard HUNT, THE AMERICAN PASSPORT 4-6 (Washington, U.S. Gov't Printing Office 1898); PASSPORT OFFICE, U.S. DEP'T OF STATE, THE UNITED STATES PASSPORT 1-40 (1976). But how can this assumption be textually justified? The passport power finds no evident basis in any of the President's specific constitutional powers, nor does it seem to be an aspect of enforcing the laws in general. And, as before, it is no answer to say that the power comes from congressional authorization, as in practical effect it has since 1856, since no provision of the Constitution appears to grant Congress this power either. 
A second example of controverted power is the authority to enter into "executive agreements" - that is, international agreements concluded by the President alone, without the Senate's consent. ${ }^{64}$ The Supreme Court has approved the President's making of "nontreaty" agreements under certain circumstances, ${ }^{65}$ and there is a long practice in support of them. ${ }^{66}$ Foreign affairs scholarship-which has bitterly debated their validity ${ }^{67}$ - has no defensible explanation of how they fit into the Constitution's text. On one hand, scholars such as David Gray Adler and Raoul Berger view executive agreements as presidential usurpations, arguing that the Treaty Clause of Article II, Section 2 provides the exclusive method of entering into international agreements ${ }^{68}$ But this cannot be correct as a textual matter, for the Constitution's text contemplates some international agreements that are not treaties. In speaking of the international powers of the states, Article I, Section 10 refers to treaties and other international agreements. ${ }^{69}$ The Adler/Berger scholarship has no satisfactory response to the observation that the Constitution's text explicitly contemplates various levels of international agreements, only one of which is effected through Article II, Section $2 .^{70}$ Their principal retort is that accepting such a presidential power would give too much control (by their standards) over foreign affairs to the President. ${ }^{11}$

On the other hand, the other side in this debate is on no firmer constitutional ground. Although the Constitution appears to contemplate nontreaty agreements, the President has no obvious source of power to

64. See HENKIN, supra note 5, at 215-24 (discussing executive agreements).

65. See Dames \& Moore v. Regan, 453 U.S. 654 (1981); United States v. Pink, 315 U.S. 203 (1942); United States v. Belmont, 301 U.S. 324 (1937).

66. See Wallace MCClure, International Executive agreements 35-99 (1941); Myres S. McDougal \& Asher Lans, Treaties and Congressional-Executive or Presidential Agreements: Interchangeable Instruments of National Policy, 54 YALE L.J. 181, 212-16 (1945).

67. Compare Adler, supra note 7, at 27-32 (opposing executive agreements), and Raoul Berger, The Presidential Monopoly of Foreign Relations, 71 MICH. L. REV. 1, 55 (1972) (same), with MCCLURE, supra note 66, at 254-64 (endorsing executive agreements), and McDougal \& Lans, supra note 66, at 186-88 (same).

68. Adler, supra note 7, at 27-32; Berger, supra note 67, at 55 .

69. U.S. CONST. art. I, \&10. Moreover, this cannot be mere surplusage, for the Constitution treats some international agreements differently from treaties. $I d$. (providing that states may not enter into treaties, but may cnter into other international agreements with the consent of Congress); see also Ramsey, supra note 3 , at $162-63 \& \mathrm{n} .126$ (expanding on this argument).

70. Once one accepts that the Constitution contemplates both treaties and nontreaty agreements, a related question is how to tell the difference. Foreign affairs scholarship also has no consensus as to what type of agreement must be done by treaty and what may be done by nontreaty agreement. One of the present authors has attempted a distinction based on the text and original understanding of the Constitution. See Ramsey, supra note 3, at 183-205 (arguing that nontreaty agreements should be confined to short-term or unimportant undertakings); see also Bradford Clark, The Judicial Safeguards of Federalism, 79 TEx. L. REv. 1321, 1444-52 (2001) (embracing this distinction as part of a larger structural analysis of the Constitution).

71. Adler, supra note 7, at 27-32; Berger, supra note 67, at 55 . 
conclude them. ${ }^{72}$ Following the Supreme Court on this matter, supporters of executive agreements rely on either an inherent presidential power, derived from Curtiss-Wright and explicitly embraced by the Court in the Pink and Belmont cases shortly afterward ${ }^{73}$ or an outgrowth of custom and practice, as emphasized by the modern Court in Dames \& Moore v. Regan..$^{74}$ Neither argument, of course, arises from constitutional text, but rather assumes that the text itself does not address the matter. ${ }^{75}$

A further example is the power to terminate treaties, as debated inconclusively by the courts in Goldwater $v$. Carter. ${ }^{76}$ There are three plausible candidates, each with their academic supporters: the President, the President with the consent of the Senate, and Congress. ${ }^{77}$ Nothing in the Constitution's text seems directly addressed to this question, and the leading proponents of each side quickly dismiss the text and reach for other authorities. Professor Adler, who would require senatorial consent for termination, argues that the entity that takes an action logically is the entity that can undo the action, but he makes no attempt to find any support in the Constitution's text. ${ }^{78}$ Similarly, Professor Glennon, arguing in favor of congressional authority, observes that:

72. This is especially truc once one recognizes, as set forth above, that modern foreign affairs scholarship has provided no textual ground for supposing that the President even has the power to speak for the United States in foreign affairs.

73. United States v. Pink, 315 U.S. 203, 222-23 (1942); United States v. Belmont, 301 U.S. $324,330-32$ (1937).

74. 453 U.S. 654, 679-80 (1981) (emphasizing the long period of congressional acquiescence in claims settlement by executive agreement). This view, of course, does not pause to consider whence Congress might derive the power to settle private claims.

75. Professor Henkin also finds that the Constitution simply does not speak to the matter: "One is compelled to conclude that there are agreements which the President can make on his sole authority and others which he can make only with the consent of the Senate (or of both houses), but neither Justice Sutherland nor anyone else has told us which are which." HENKIN, supra note 5 , at 222 (footnote omitted). Professor Powell also finds the question without a constitutional answer; the best he can conclude is that "although a sole executive agreement may well have international law implications, its legal force from the standpoint of the United States legal system seems debatable." Powell, supra note 3, at 560. For an attempt to explain the constitutional status of executive agreements consistent with the present study, see Ramsey, supra note 3, at 206-18.

76. See Goldwater v. Carter, 481 F. Supp. 949 (D.D.C.), rev'd, 617 F.2d 697 (D.C. Cir.), vacated, 444 U.S. 996 (1979). The constitutional question in Goldwater $v$. Carter was whether President Carter acted constitutionally in notifying Taiwan of termination of the United StatesTaiwan defense treaty in accordance with the treaty's termination provisions.

The issue has recently recurred in connection with President Bush's suggestion that he might give notice of termination of the Anti-Ballistic Missile Treaty between the United States and the former Soviet Union. See Bruce Ackerman, Treaties Don't Belong to the President Alone, N.Y. TIMES, Aug. 29, 2001, at A23 (urging Congress to assert a role in the decision to terminate the Treaty).

77. On the debate, see HENKIN, supra note 5, at 211-14.

78. DAVID GRAY ADLER, THE CONSTITUTION AND THE TERMINATION OF TREATIES 84-113 (Harold Hyman \& Stuart Bruchey eds., 1986). Among other problems, Professor Adler's view seems in considerable tension with the common understanding of the power to remove executive officers. 
The constitutional text does not address the matter... The intent of the Framers is thoroughly ambiguous....

The issue, thus, is which of the political branches is best suited to make the determination that [a treaty] should be terminated, taking into account factors such as the need for swiftness versus deliberation and secrecy versus diverse viewpoints. ${ }^{79}$

Professor Henkin would apparently give the power to the President on the basis of practice and practicality. In his view, "the Constitution tells us only who can make treaties for the United States; it does not say who can unmake them." 80

A final example is the question whether the President may make law in support of foreign affairs objectives. Presidents have often claimed, and the Supreme Court has occasionally appeared to uphold, some presidential lawmaking authority in foreign affairs. President Reagan, for example, issued orders implementing the executive agreement ending the Iran hostage crisis - an agreement that itself did not rest on any statutory approval. The Supreme Court accorded those orders the force of law in Dames \& Moore v. Regan without explaining how law could arise in the absence of a treaty or legislation. ${ }^{81}$

At the same time, those who would limit presidential lawmaking in foreign affairs fare no better. Such scholars emphasize the President's ordinary role as law-enforcer, not law-maker. For instance, Professor Henry

79. GLENNON, supra note 13 , at 151 .

80. HENKIN, supra note 5, at 211. Professor Powell also finds the question unresolvable on textual grounds, and even after canvassing custom and precedent concludes that " [ $t$ ]he power of Congress to terminate a treaty over the President's direct objections is unclear." Powell, supra note 3, at 563. The Restatement of Foreign Relations Law, on the other hand, flatly declares that "[u]nder the law of the United States, the President has the power . . . to suspend or terminate an agreement in accordance with its terms," citing no provision of the Constitution and three inconclusive Supreme Court cases. RESTATEMENT (THIRD) OF FOREIGN RELATIONS LAw OF THE UNITED STATES $\$ 339$ (1987). But see GLENNON, supra note 13, at 148-49 \& n.146 (criticizing the Restatement).

81. 453 U.S. $654,669-74$ (1981). But see Clark, supra note 70, at 1444-52 (objecting to the assumed preemptive power of executive agreements); Ramsey, supra note 3, at 218-35 (same). In a more controversial example, President Nixon attempted to prevent the publication of sensitive papers relating to the Vietnam War, in the matter that became famous as the Pentagon Papers Case. N.Y. Times Co. v. United States, 403 U.S. 713 (1971). The Supreme Court rejected the President's attempt as a matter of First Amendment law, but only remarked in passing that the President was attempting to create a legal obligation (not to publish the papers) in the name of national security unsupported by congressional enactment. See id. at 718 (Black, J., concurring) (noting that "[t]he Government does not even attempt to rely on any act of Congress" in seeking the injunction); id. at 732 (White, J., concurring) ("The Government's position is simply stated: the responsibility of the Executive for the conduct of the foreign affairs and for the security of the Nation is so basic that the President is entitled to an injunction ...."). Justice Marshall, however, emphasized this point in a concurrence. See id. at 742 (Marshall, J., concurring) ("The Constitution ... did not provide for government by injunction in which the courts and the Executive Branch can 'make law' without regard to the action of Congress."). 
Monaghan argues that if an "implied law-making authority [in foreign affairs] can inhere in the general grants of executive power" then "the fundamental premises of the constitutional order are overturned," 82 and Professor Henkin says that "[n]o one has suggested that under the President's 'plenary' foreign affairs powers he can, by executive act or order, enact law directly regulating persons or property in the United States." ${ }^{83}$ But Professor Monaghan concedes that "virtually every modern commentator acknowledges 'the very delicate, plenary and exclusive power of the President as the sole organ of the federal government in the field of international relations." ${ }^{84}$ Why, then, should that power not include some lawmaking authority? Since scholars cannot explain the constitutional origins of the "sole organ" power, it is not clear why, as a textual matter, modern scholars categorically dismiss presidential lawmaking in foreign affairs ${ }^{85}$ Indeed, Professor Henkin admits that some instances of executive lawmaking-particularly with respect to executive agreements-have occurred, and confesses inability to judge whether these instances represent only "the President's power to make special law in special circumstances, or ... some broad principle of presidential 'legislative power' in foreign affairs." ${ }^{86}$ Modern scholarship has thus been unable to address satisfactorily the question whether the President's foreign affairs powers include some lawmaking authority.

In short, the Constitution's text plays little role in modern scholarship's attempts to allocate many specific and significant foreign affairs powers between the President and Congress. Modern scholarship agrees on some presidential foreign affairs powers, such as communication with foreign nations and recalling U.S. ambassadors, but it cannot explain how the

82. Henry P. Monaghan, The Protective Power of the Presidency, 93 COLUM. L. REV. 1, 55 (1993); see also Youngstown Sheet \& Tube Co. v. Sawyer, 343 U.S. 579, 586 (1952) (rejecting the President's claim of lawmaking authority and concluding that " [t]he Constitution limits [the President's] functions in the lawmaking process to the recommending of laws he thinks wise and the vetoing of laws he thinks bad"); Yoo, supra note 4, at 2235 n.56 (reviewing leading theories of presidential power and noting that "none of these theories [of executive power] recognize an executive authority to legislate upon the legal rights and duties of American citizens").

83. HENKIN, supra note 5 , at 54.

84. Monaghan, supra note 82, at 48 (quoting United States v. Curtiss-Wright Export Corp., 299 U.S. 304, $320(1936)$ ).

85. Professor Monaghan declares that " $[\mathrm{t}]$ he Constitution contemplates no such law-making prerogative in the President" because otherwise "the congressional role [in foreign affairs] would be substantially limited to that of a checking function." $I d$. at 55 . But this argument, resting on no constitutional text, simply leads back to the original unanswerable question: Who has the primary role in foreign affairs? If the President does, perhaps Congress should have only a checking function. And as discussed above, modern scholarship concedes that this question cannot be resolved by reference to constitutional text.

86. HENKIN, supra note 5 , at 57 . Since no one can explain the mechanism by which executive agreements achieve the status of law, no one can say that other presidential actions might not also have that status. As a result, Professor Henkin characteristically finds the ultimate answers beyond constitutional analysis: "Issues of Presidential power, in particular, remain to be fought out in the consciences of the Executive branch and in the political arena." Id. at 61 . 
Constitution grants the President these powers. Modern scholarship disagrees on the allocation of many other specific powers, including formulating foreign policy, entering into executive agreements, terminating treaties, and implementing foreign policy as law. But there is a scholarly consensus that the Constitution's text has nothing useful to say about these powers.

\section{A COMPREHENSIVE TEXTUAL THEORY OF FoREIGN AFFAIRS}

We think better of our Constitution's text. In particular, we find unpersuasive modern foreign affairs scholarship's claim that the Constitution's text simply ignores fundamental questions of foreign affairs law. In effect, modern scholars would have us believe that as the Philadelphia delegates struggled to work out a new government, they wholly neglected leading questions of foreign affairs law; that the ratifying conventions accepted the Constitution despite its supposedly evident foreign affairs gaps; and that the first federal politicians were wholly oblivious to the serious foreign affairs gaps in the Constitution.

We think all this highly unlikely. We think it far more plausible that the Constitution's drafters and ratifiers did have a basic understanding of the allocation of foreign affairs powers within the new government, and that the document they produced and ratified, properly interpreted, reflects this understanding. The statesmen who gathered in Philadelphia in 1787 thought carefully about the structure of their new government and its allocation of powers. In particular, they thought carefully about foreign affairs, for the Articles of Confederation's deficient treatment of foreign affairs was a leading reason for their meeting. ${ }^{87}$ Similarly, the ratifying conventions discussed foreign affairs at length, and, in implementing the Constitution, the Washington Administration faced numerous foreign affairs challenges. Yet no one during this time pointed to the Constitution's supposed gaps in foreign affairs. We think this is because the Constitution, rather than being "strangely laconic" regarding foreign affairs, is positively voluble. In this Part, we defend a textual framework that reveals exactly how our Constitution speaks to foreign affairs.

\section{A. Four Principles of Constitutional Foreign Affairs Powers}

In our view, the Constitution's text reflects a foreign affairs framework that can be described with four basic principles. First, the President's executive power includes a general power over foreign affairs. By the first

87. See FREDERICK W. MARKS III, INDEPENDENCE ON TRIAL 52-95 (1973); JACK N. RAKOVE, THE BEGINNINGS OF NATIONAL POLITICS 275-329 (1979). 
sentence of Article II, "the executive Power shall be vested" in the President. ${ }^{88}$ Executive power, as commonly understood in the eighteenth century, included foreign affairs powers. As we elaborate below, Locke, Montesquieu, and Blackstone, the great political philosophers most familiar to the Framers, said that foreign affairs powers were part of the executive power. ${ }^{89}$ Under the English system, as these writers described it, the Crown's powers over foreign affairs arose from its executive power. This was also the terminology of American writers and political leaders immediately before, during, and after the Constitution's ratification. Hence, in 1787, when the Constitution provided that the President would have "the executive Power," that would have been understood to mean not only that the President would have the power to execute the laws (the primary and essential meaning of "executive power" ${ }^{90}$ ), but also that the President would have foreign affairs powers. As a result, the starting point is that foreign affairs powers are presidential, not from some shadowy implication of national sovereignty, per Curtiss-Wright, but from the ordinary eighteenth-century meaning of executive power. ${ }^{91}$

Second, the President's executive foreign affairs power is residual, encompassing only those executive foreign affairs powers not allocated elsewhere by the Constitution's text. The Constitution's allocation of specific foreign affairs powers or roles to Congress or the Senate are properly read as assignments away from the President. Absent these specific allocations, by Article II, Section 1, all traditionally executive foreign affairs powers would be presidential. Perhaps, one could say from the text alone, some of the specific allocations might only grant Congress a shared power and not deny it to the President. The War Power Clause, for example, says only that Congress can declare war, not (in so many words)

88. U.S. CONST. art. II, $\S 1$.

89. See infra Part III.

90. See Prakash, supra note 2.

91. Critics of our theory might suggest that ours is one based on the "inherent" rights or prerogatives of the President. They might misconstrue our argument as asserting that the President simply must have power over foreign affairs because that is what it means to be a president. Nothing could be further from the truth. We emphatically reject the notion that our arguments amount to a claim that the President has inherent rights. Indeed, we deny that a "president" has any inherent rights. Instead, our claim is that the phrase "executive power" had a foreign affairs component in the late eighteenth century. Because we are making an assertion about the meaning of a power granted to the President (the executive power), we are no more making a claim about inherent power than someone who claims that Congress can regulate navigation because it has the power to regulate commerce. By Article II, Section 1, the President has the executive power; our goal is to show one specific attribute of the executive power.

Moreover, we are not saying that the executive power inherently includes foreign affairs powers. Words do not have inherent meanings, as words can come to mean whatever we would have them mean. Hence while water has inherent qualities (for example, it is wet), words such as executive power do not have inherent meanings. This Article merely makes a claim about the meaning of executive power at a particular time in history, not about what executive power must mean in the abstract. 
that the President cannot. But, as we describe below, it is clear from context that everyone at the time understood the War Power Clause (and others like it) as giving the power to Congress and denying it to the President. The Constitution's drafters believed that the English system afforded too much foreign affairs power to the monarch through the undivided possession of the executive power, and that some aspects of the traditional executive power over foreign affairs had legislative overtones (including the war and treaty-making powers). ${ }^{92}$ Accordingly, they divided the traditional executive power over foreign affairs by creating specific (but very substantial) exceptions to the general grant of executive power to the President. In the document they created, many key foreign affairs powers were either shared-such as the power to appoint ambassadors or make treaties-or allocated elsewhere-such as the power to declare war and issue letters of marque. As a result, once the drafting was complete, the President had a greatly diminished foreign affairs power as compared to the English monarchy. ${ }^{93}$ But the President retained a residual power-that is, the President, as the possessor of "the executive Power," had those executive foreign affairs powers not allocated elsewhere by the text. In short, far from suffering from huge gaps, the Constitution has a simple default rule that we call the "residual principle" : Foreign affairs powers not assigned elsewhere belong to the President, by virtue of the President's executive power; while foreign affairs powers specifically allocated elsewhere are not presidential powers, in spite of the President's executive power.

Third, the President's executive power over foreign affairs does not exceed the powers of the eighteenth-century English monarch over foreign affairs. This is a necessary corollary to the first principle, by which the President derives residual foreign affairs authority from the ordinary eighteenth-century understanding of "executive power." If the English monarch, the executive most immediately described by Locke, Montesquieu, and Blackstone, lacked a certain power, one would not think that the ordinary understanding of executive power could encompass it. Although the Crown had great power over foreign affairs, two powers that it generally lacked were the powers of legislation and finance. With limited

92. Infra text accompanying notes 221-222.

93. Some scholars have argued that these specific allocations show an intent to deny all foreign affairs powers (other than those specifically listed in Article II, Sections 2 and 3) to the President. E.g., Stein, supra note 3, at 487 (making this claim and citing further authorities). We think the specific allocations show exactly the opposite. The Framers understood that Article II, Section 1 would be read to convey all foreign affairs power to the President and thought this gave too much. They solved the problem not by giving general authority ovcr foreign affairs to Congress or the Scnate, but by taking specific foreign affairs powers away from the President and allocating them elsewhere. As a result, foreign affairs powers not specifically taken away remain with the President. 
exceptions, the Crown relied on Parliament to enact legislation and appropriate money in support of foreign policy goals. Because executive power did not include these powers, they were not granted to the U.S. President as a residual element of the executive power over foreign affairs. Congress has the appropriations power, unconstrained by any constitutional obligation to support presidential foreign affairs initiatives (since that obligation never existed in the English Parliament), ${ }^{94}$ and Congress (and not the President) has the power to make law in support of foreign policy goals because the traditional executive power did not include the power to enact foreign affairs legislation. ${ }^{95}$

Fourth, Congress has only its specifically enumerated powers in foreign affairs, but these include a power to legislate in support of the President. A textual approach compels the conclusion that Congress has only the powers granted to it by the text. ${ }^{96}$ No provisions in Article I, Section 8 (the relevant text), either considered individually or taken together, amount to a comprehensive congressional authority over foreign affairs. But Congress has two important sources of lawmaking authority that, taken together, almost add up to a general power. ${ }^{97}$ Congress, of course, enjoys explicit legislative powers in particular areas of foreign affairs, such as the power to regulate foreign commerce, declare war, etc., plus the power to make laws "necessary and proper" to effectuate these powers. ${ }^{98}$ From our second and third principles, it should be clear that these are independent powers of Congress, which can be exercised despite presidential opposition. ${ }^{99}$ In addition, Congress also may invoke the Necessary and Proper Clause to carry into execution the powers granted to the President by the Constitution. From our first principle, this includes the power to carry into execution the President's residual foreign affairs powers. Thus Congress has the general power to legislate in support of the

94. See John C. Yoo, Globalism and the Constitution: Treaties, Non-Self-Execution, and the Original Understanding, 99 COLUM. L. REV. 1955, 1997-2004 (1999).

95. See JAMES WILSON, Lectures on Law, in 1 THE WORKS OF JAMES WILSON 440 (Robert Green McCloskey ed., Harvard Univ. Press 1967) (1804) (discussing the traditional understanding of executive power and concluding that "[t]he person at the head of the executive department had authority, not to make, or alter, or dispense with the laws"); Yoo, supra note 94, at 2000 (noting the English monarch's inability to make law through treaties). In the U.S. system, some lawmaking can be done by the President in combination with the Senate in the form of treaties, pursuant to Article II, Section 2, and Article VI. Of course, the residual principle does not mean that the President utterly lacks power over matters allocated to Congress, since the President can shape the foreign affairs laws Congress passes by use of the veto.

96. But cf. HENKIN, supra note 5, at 71 (identifying Congress's foreign affairs powers as arising outside the text, and indeed outside the Constitution).

97. We do not consider here any federalism-based limitations on this power, see Curtis A. Bradley, The Treaty Power and American Federalism, 97 MICH. L. REV. 390 (1998), or limitations based on other structural or individual rights provisions contained elsewhere in the document. These, of course, may be substantial.

98. U.S. CONST. art. I, $\$ 8$, cl. 18.

99. That is, in the face of contrary presidential policies and even over a presidential veto. 
President's foreign policy goals. But this general power-unlike Congress's specifically enumerated powers-is subject to a key limitation. Since it is derivative of the President's power, it must be exercised in coordination with, and not in opposition to, the President. ${ }^{100}$

As a result the Constitution achieves a complex series of interbranch checks in foreign affairs. The President has a residual executive power, which means that only the President can speak for the United States on the international stage and can formulate foreign policy (narrowly understood). ${ }^{101}$ At the same time, the President must rely on Congress (or two-thirds of the Senate) to give foreign policy any domestic legal effect. Congress can pursue foreign affairs goals independently from the President through legislation in areas where it has a specifically enumerated power, such as foreign commerce. In other areas, where Congress has only derivative power, it can act to support the President (or it can refuse to act), but it cannot pursue independent objectives. No single branch, acting alone, has complete control over the course of U.S. foreign affairs.

\section{B. A Textual Defense of the Four Principles of Foreign Affairs Powers}

Having outlined our four basic principles, in this Section we show why our textual claims make the most sense of the Constitution.

First, our interpretation accords with the way "executive power" was commonly used in the eighteenth century. Alternative readings either dismiss this prominent provision as an empty, decorative preface to Article II, or deny that it has the meaning in the Constitution that it did in eighteenth-century usage. Neither of these positions seems tenable. As to the Clause's supposed lack of any content, some scholars have argued in other contexts that the general grant of "the executive Power" likely lacks any independent substance, since it is followed by an enumeration of specific powers. Yet when one compares the introductory clauses of the first three Articles, the Article II Vesting Clause must be read as a grant of power. The Article I Vesting Clause explicitly indicates that Congress's legislative powers only extend to those powers "herein granted." 102 The

100. Congress also may employ the Necessary and Proper Clause to carry into execution its own foreign affairs powers. We emphasize the congressional power to support the President's foreign affairs powers because this power has not commonly been recognized and because it has considerable scope. Congress's power to carry into execution its own powers does not allow Congress to move far beyond its specifically enumerated foreign affairs powers and does not encompass anything approaching a generic power over foreign affairs. In contrast, the power to carry into execution the President's foreign affairs powers is a considerable augmentation of Congress's specifically enumerated powers.

101. The President can determine the content of communications expressing the views of the United States on international matters. See supra note 56.

102. U.S. CONST. art. I, § 1 ("All legislative Powers herein granted shall be vested in a Congress of the United States, which shall consist of a Senate and House of Representatives."). 
Article II Vesting Clause lacks such language, thereby suggesting that it may vest powers beyond those subsequently enumerated. ${ }^{103}$ Moreover, the Judicial Power Clause-Article III's counterpart to the Executive Power Clause-must vest power with the federal judiciary, because it is the only clause that could possibly vest any power with the federal judiciary. ${ }^{104}$ Indeed, if that Clause grants no authority, federal judges lack a constitutional basis for their actions; save for salary and tenure, they would be mere creatures of statute. If the Judicial Power Clause grants authority, the analogous Executive Power Clause must bestow power as well because the Clauses are virtually in haec verba. ${ }^{105}$

Once one accepts that the Vesting Clause bestows some power, it is difficult to argue, in keeping with eighteenth-century understandings, that it does not convey foreign affairs power. As we elaborate below, political theorists such as Locke, Blackstone, and Montesquieu, and leading members of the constitutional generation in the United States, including Washington, Jefferson, Madison, Hamilton, and an array of lesser figures, used executive power in various contexts to include foreign affairs powers. ${ }^{106}$

Second, our theory demonstrates how the Constitution completely allocates foreign affairs authority. Although we would not contend that the Constitution addresses every problem of governance, we think it appropriate to prefer a reading that does not yield enormous and troubling gaps. As discussed above, every competing theory believes that the Constitution's text fails to address many key issues of foreign affairs power. ${ }^{107}$ In particular, every other theory agrees that the President's powers in Article II plus Congress's powers in Article I, Section 8 do not encompass all foreign affairs powers. As a result, "missing" powers must be found from implications unsupported by text or assumed as inherent attributes of sovereignty-or else it must be concluded that the Constitution's text (intentionally or not) failed to grant the federal government important foreign affairs powers. Moreover, these powers must then be allocated by a host of extratextual sources. Our theory, in contrast, derives a complete textual allocation. Hence, there is no need to reach

103. Id. art. II, $\$ 1$, cl. 1 ("The executive Power shall be vested in a President of the United States of America."); Frank B. Cross, The Surviving Significance of the Unitary Executive, 27 Hous. L. REv. 599, 613 n.92 (1990); Morton J. Frisch, Executive Power and Republican Government-1787, 17 PRESIDENTIAL STUD. Q. 281, 287 (1987).

104. Steven G. Calabresi \& Kevin H. Rhodes, The Structural Constitution: Unitary Executive, Plural Judiciary, 105 HARV. L. REV. 1153, 1176 (1992).

105. Compare U.S. CONST. art. III, $\S 1$ ("The judicial Power of the United States, shall be vested in one supreme Court, and in such inferior Courts as the Congress may from time to time ordain and establish."), with id. art. II, \& 1, cl. 1 ("The executive Power shall be vested in a President of the United States of America.").

106. Infra Parts III-VII.

107. Supra Part I. 
outside the Constitution to justify the President's communicative and policymaking powers over foreign affairs, or Congress's limited ability to legislate with respect to foreign affairs matters not contained within the specific clauses of Article I, Section 8.

Moreover, we cannot imagine any other plausible reading of the text that would give a full allocation of foreign affairs power. Many key foreign affairs powers that surely would have been known to the Framers cannot be encompassed by an ordinary reading of the specific provisions of the Constitution: among others, the power to set foreign policy and speak internationally on behalf of the United States, the power to direct and to recall ambassadors, the power to enter into nontreaty agreements, the power to terminate treaties, and the power to implement foreign affairs powers legislatively in areas not covered by Congress's specifically enumerated powers. ${ }^{108}$ Because many crucial foreign affairs powers are not specifically mentioned, to give a complete reading one must identify somewhere in the text a "residual" power that encompasses foreign affairs powers not specifically apportioned. We see no plausible alternatives to Article II, Section 1 as the source of that residual power. ${ }^{109}$

108. It might be supposed that many, if not all, of these powers could be encompassed within the President's power over ambassadors. But on closer examination this seems insufficient. The President's only textually explicit and fully independent power in this regard is to receive foreign ambassadors, which, no matter how greatly stretched, could not cover most of the apparently unmentioned powers, such as communications effected through U.S. ambassadors or recall of U.S. ambassadors. True, the President, with the Senate, has the power to appoint U.S. ambassadors by Article II, Section 2. But if this is the source of the power to speak for the United States, that power would seem to be shared with the Senate-an arrangement unworkable in theory and never followed in practice. Moreover, even if the President did have an independent Article II, Section 2 power over U.S. ambassadors, much formation and announcement of foreign policy is not done through ambassadors, nor was it so done in the eighteenth and nineteenth centuries. See supra Section I.B (discussing the Neutrality Proclamation and the Monroe Doctrine). Accordingly, we agree with the overwhelming majority of foreign affairs scholars who have concluded that the specific allocations of power in the text cannot be stretched to add up to a complete treatment of foreign affairs powers. Supra Part I (discussing authorities). We differ, however, in thinking that the text provides a residual allocation of powers that are not specifically allocated.

109. One possible candidate is the Necessary and Proper Clause of Article I, Section 8, Clause 18, which might be read to give Congress complete power over the direction of foreign policy. Each foreign policy objective, on this view, would require legislative authorization; the President would communicate foreign policy as part of the power to execute the laws (in this case, the laws establishing foreign policy). But this argument founders on the difficulty that Congress's enumerated powers do not cover all categories of foreign affairs power. See HENKIN, supra note 5 , at 71 . Since the necessary and proper power is only ancillary to enumerated powers, it cannot be relied upon to create legislative powers unrelated to enumerated powers. One might further argue that the residual power arises from the combination of the Declare War Clause and the Necessary and Proper Clause. Any exercise of foreign affairs power, this argument might run, is ancillary to the declare-war power, since any interaction with a foreign nation, depending on how it is handled, could provoke or avoid war. This argument seems an unnatural stretch of the declare-war power. War declaration, however broadly understood, is only part of foreign affairs activities. It seems odd to suggest that the Framers viewed war as their principal interaction with foreign nations. In addition, this interpretation creates substantial redundancies. If Congress has a residual foreign affairs power from Clauses 11 and 18 of Article I, Section 8, that power should 
Third, we do not see any compelling textual arguments against our position. The principal objection based on text alone, we imagine, is that reading "the executive Power" to include unallocated foreign affairs power renders superfluous some of the specific allocations of Article II, Sections 2 and 3. Obviously this is not true with respect to the allocation of treaty power and appointment of ambassadors, as these clauses, by granting a senatorial role, qualify what otherwise would be in our view exclusive presidential powers. But perhaps some might believe that the Commanderin-Chief power and the authority to receive ambassadors could be derived from our view of "the executive Power" even if not specifically listed in Article II, Sections 2 and 3.

We do not believe that our reading renders the Commander-in-Chief Clause redundant. The Constitution grants Congress substantial military powers not only to declare war, but also to "raise and support Armies"; to "provide and maintain a Navy"; to "make rules for the Government and Regulation of the land and naval forces"; and to "provide for organizing, arming and disciplining the Militia." 110 Absent the Commander-in-Chief Clause, even the most steadfast believer in the President's residual foreign affairs powers might conclude that Congress enjoys all military powers. The Commander-in-Chief Clause ensures shared power over the military despite the substantial grants to Congress. ${ }^{11}$

The power to receive ambassadors, on the other hand, probably would lie with the President as part of "the executive Power" even without the express declaration in Article II, Section 3. But even in the absence of an

include matters such as regulation of foreign commerce, punishment of violations of the law of nations, and issuance of letters of marque. In short, we think any interpretation that would give a residual foreign affairs power to Congress creates substantially more tensions with the text and structure of the Constitution than does our reading of " the executive Power."

Akhil Amar has tentatively suggested that Congress's power over international commerce grants it a general, residual power over foreign affairs. We regard Professor Amar's suggestion as thought-provoking but ultimately flawed. We agree with Chief Justice Marshall that commerce includes intercourse and navigation, but we doubt that anyone understood that power as broadly as it would have to be construed in order for it to encompass foreign affairs generally. First of all, we know of no political theorist who wrote of the commerce power as a font of foreign affairs powers generally. Second, we know of no Framer or ratifier who understood the commerce power as a grant of general foreign affairs powers. Third, we know of no one during the Washington Administration or in the early Congresses who claimed that the commerce power granted Congress a generic power to legislate foreign affairs. See Randy E. Barnett, The Original Meaning of the Commerce Clause, 68 U. CHI. L. REV. 101 (2001). Hence, although Amar's hypothesis has some surface textual plausibility and has the added benefit of taking text seriously, we think his suggestion about the scope of the Commerce Clause is incorrect.

110. U.S. CONST. art. I, $\S 8$.

111. The combination of the Executive Power Vesting Clause and the Commander-in-Chief Clause could be read together in several ways-for example, that all of the President's military power comes from the Commander-in-Chief power; that all of the President's military power comes from the Executive Vesting Clause and that the Commander-in-Chief Clause was inserted to guard against mistaken interpretations; or that the President's military powers arise from a combination of the two clauses. See Yoo, supra note 3 . In no case, however, could the Commander-in-Chief Clause be described as redundant (i.e., serving no purpose). 
explanation for this Clause, we think that a small redundancy should not defeat the entire theory, especially in the absence of a competing theory that provides a more satisfactory textual explanation. ${ }^{112}$ Indeed, we regard our reading as entirely consistent with eighteenth-century drafting principles. As James Madison explained: "Nothing is more natural nor common than first to use a general phrase, and then to explain and qualify it by a recitation of particulars." 113 Following the general principle established by vesting the executive power with the President, Sections 2 and 3 explain and qualify the general principle. ${ }^{114}$

Fourth, our approach is consistent with broader principles of separation of powers and checks and balances. We agree with Professor Koh's observation that "the Founding Fathers framed the constitutional provisions on foreign affairs with two goals in mind-to fashion a stronger national government while holding each branch of that government accountable to the others through a strong system of checks and balances." 115 We also agree with Professor Koh's further observation that "the Framers rejected the option of centralizing the national government's foreign affairs powers in the president alone",;16 and with Professor Henkin's statement that "the Framers were hardly ready to replace the representative inefficiency of many with an efficient monarchy, and unhappy memories of royal prerogative, fear of tyranny, and reluctance to repose trust in any one

112. See Akhil Reed Amar, Some Opinions on the Opinion Clause, 82 VA. L. REV. 647, 64753 (1996). Amar first rejects the view that "each [constitutional] clause must add something new." Id. at 648. Citing the Necessary and Proper Clause and much of the Bill of Rights (including the First, Fifth, Sixth, Ninth, and Tenth Amendments), he shows that "[e]ven a casual look at the Constitution reveals clauses that are in some sense redundant or superfluous." Id. Given the powerful case for ascribing a foreign affairs meaning to executive power, we should reject the notion that the maxim against redundant constructions must be applied rigidly and without fail. Instead, we must apply this maxim "sensitively and contextually to aid sound construction" and avoid it when it would defeat "common sense and interpretive aesthetics." Id. at 650 .

113. The FEDERAlist NO. 41, at 272 (James Madison) (Isaac Kramnick ed., 1987). Hamilton also believed that the general clause should be construed broadly:

It would not consist with the rules of sound construction, to consider this enumeration of particular authorities as derogating from the more comprehensive grant in the general clause... The difficulty of a completc cnumeration of all the cases of executive authority would naturally dictate the use of general terms, and would render it improbable that a specification of certain particulars was designed as a substitute for those terms, when antecedently used.

AleXANDER Hamilton, LetTers of Pacificus No. 1 (June 29, 1793), reprinted in 4 THE WORKS OF ALEXANDER HAMILTON 432, 438 (Henry Cabot Lodge ed., 1904); cf. Calabresi \& Rhodes, supra note 104 (making a similar argument with respect to Article III).

114. Redundancy avoidance simply cannot play a decisive role here, for every reading of the Vesting Clause (of which we are aware) yiclds some redundancy. For instance, if the Executive Power Clause merely announces the title and number of federal executives, as some have suggested, then the clause is wholly redundant because the rest of the Constitution makes clear that there shall be but one executive called the President. See Prakash, supra note 2.

115. КоH, supra note 3, at 74-75.

116. Id. at 75 . 
person, kept the Framers from giving the new President too much head." 117 Scholars of foreign affairs summarily dismiss the grant of executive power as a source of foreign affairs power on the ground that such a reading would give the President unchecked power. ${ }^{118}$ But as we emphasize throughout this Article, our residual principle does not yield presidential supremacy in foreign affairs. Although "the executive Power" contains substantial foreign affairs powers, it is checked by substantial limitations: the grant of some formerly "executive" foreign affairs powers to Congress, the sharing of some "executive" powers with the Senate, Congress's power over appropriations and foreign affairs legislation, and the President's lack of independent lawmaking power.

Finally, our interpretation is remarkably consistent with Founding-era definitions, commentary, and practice. ${ }^{119}$ As we illustrate below, discussions of the allocation of foreign affairs power in this period show a broad consensus about the meaning of executive power and a general understanding that the President had foreign affairs powers beyond those specifically enumerated. To be sure, there was some disagreement on the scope of the executive power, but no one made a sustained and coherent argument that the executive power did not encompass some foreign affairs powers. Moreover, although President Washington exercised generic foreign affairs powers that he and his advisers attributed to the executive power, he also generally observed the constitutional limits upon those powers that we have identified. ${ }^{120}$

117. HENKIN, supra note 5, at 27-28.

118. See supra Section I.A.

119. See infra Parts III-VII.

120. Some might make a prudential argument in favor of our residual theory: As compared to Congress, the President is always on duty and hence is a superior repository of a power that requires constant vigilance. Indeed, because Congress might not meet much of the year and could not be expected to respond with alacrity when foreign affairs issues arose, one might argue that the President simply must have residual foreign affairs powers. Notwithstanding the potential helpfulness of such an argument, we refrain from making it. Like many prudential arguments, it hardly rests on a universal truth or agreement. First, we have no doubt that congressional primacists could argue that the Framers wished to avoid quick decisions in foreign affairs and preferred having a deliberative body coolly consider foreign affairs crises. If one regards the need for lengthy deliberation as a prerequisite for proper foreign affairs decisionmaking and if one assumes a Founding-era fear of concentrated power in one person's hands, one can see why many will not be moved by a prudential argument that residual foreign affairs powers simply must reside with the unitary, responsible, ever-watchful President. Second, the experience under the Articles of Confederation suggests that the Framers of the Articles were not convinced that foreign affairs required constant vigilance. As discussed below, although the Continental Congress was not always in session, it enjoyed the executive power over foreign affairs. See infra Part IV. 


\section{Allocating "Missing" Foreign Affairs Powers}

Our four principles of foreign affairs power suggest that there is no remarkable lacuna in the foreign affairs Constitution. We do not claim that our residual principle provides a ready solution to all constitutional foreign affairs questions. We do, however, think it goes further than most modern foreign affairs scholarship in providing a textual framework with which to begin answering these questions. To give some indication of how our framework would work in practice, in this Section we consider its application to some of the foreign affairs difficulties sketched above.

As to the overall locus of foreign affairs authority, our framework occupies a middle ground between the extremes. The advocates of presidential primacy are correct to an extent in arguing that the President has powers over foreign affairs that go far beyond the powers of Article II, Sections 2 and 3 . However, these residual executive powers are subject to the three substantial limitations discussed above and not always acknowledged by presidential advocates, namely: (1) The powers explicitly conveyed to Congress by the Constitution are conveyed away from the President and are not in any sense shared powers (although the President retains some influence over them through the veto); (2) the President has no appropriations power, and no automatic right to foreign affairs funds; and (3) the President has no independent lawmaking authority in foreign affairs but depends upon Congress (or the Senate) to give presidential foreign affairs initiatives the force of law.

As to the assumed but unexplained foreign affairs powers, our framework provides solutions largely consistent with conventional assumptions and practices. The President's authority to speak for the United States in foreign affairs, and to direct and recall ambassadors, stems from the President's executive power granted by Article II, Section 1. Congress has power to regulate foreign affairs matters beyond the specific clauses of Article I, Section 8, because Article I, Section 8, Clause 18 gives Congress power to legislate in support of the President's residual power over foreign affairs. ${ }^{121}$ Thus, the basic outlines of foreign affairs authority have generally been correctly understood, although their constitutional basis has become obscured.

Our framework also suggests resolutions to previously unsettled foreign affairs disputes. To begin with an easy case, the President has the power to formulate and announce U.S. foreign policy (as presidents have done since

121. We do not mean to endorse here every instance of congressional lawmaking in foreign affairs. In particular, we emphasize a limitation that has been rarely invoked in practice: Since Congress's power (once beyond its enumerated powers) is derivative of the President's power, Congress must legislate in cooperation with the President. 
the Founding). ${ }^{122}$ That power was obviously part of the English monarch's executive power, as well as part of the executive power described by eighteenth-century political theorists. It was not conveyed to Congress (or the Senate) by any part of the Constitution; aside from its ability to declare war, Congress has no textual authority to develop or proclaim policy. Congress, of course, may pass laws, either under its enumerated powers or in support of an exercise of the President's power, and these laws may have foreign affairs effects, but Congress has no authority to declare the views of the United States on international matters, other than indirectly through legislation. ${ }^{123}$ As a result, the power to originate and declare foreign policy is part of the residual executive power over foreign affairs given the President by Article II, Section 1.

On the other hand, just as the Constitution's text assigns foreign affairs policymaking authority to the President, it assigns foreign affairs lawmaking authority to Congress. This power generally did not adhere within the traditional executive power over foreign affairs, and areas in which the executive might have been thought to have had some regulatory power-most particularly foreign commerce-were specifically assigned to Congress in the Constitution's text. Moreover, the Constitution's text gives Congress the power to "make all Laws" needed to "carry[] into Execution" all powers vested by the Constitution in any other officer of the United States. ${ }^{124}$ Lawmaking in support of foreign affairs goals, then, is not part of the President's residual power, and this allocation assures that the President must often look to Congress as a partner in foreign affairs endeavors. ${ }^{125}$

122. As noted, we mean formulation of foreign policy only in the narrow sense of determining the content of nonbinding communications on behalf of the United States. Supra note 56.

123. As an illustration, consider a U.S. policy that nations should have low tariffs to encourage the international trading system. In our view, the President decides whether to adopt this policy and announce it to the world. Congress has the power to "regulate" foreign trade and to "make laws" in support of that power, but the formulation of the low-tariff policy is neither regulating nor making law. Of course, the President's declaration of a low-tariff policy has no effect on the actual tariff rates of the United States. Congress, pursuant to its independent power to regulate foreign trade, could establish high tariffs even in opposition to the President's policy. On the other hand, Congress's high-tariff law would not bind the President's independent development of policy: The President would enforce the tariff (pursuant to the Take Care Clause of Article II, Section 2), but would be free to continue to assert a goal of low tariffs internationally, even in opposition to the thrust of U.S. law and to the desires of Congress. Thus, Congress and the President can adopt independent and conflicting views on the matter within their respective spheres of operation-Congress in passing laws, and the President in declaring U.S. foreign policy. See HAMILTON, supra note 113, at 440-42 (concluding that the branches may operate independently upon the same subject, each "in the operation of [its] own functions").

124. U.S. CONST. art. I, $\$ 8$, cl. 18 .

125. This allocation of power was specifically recognized by Justice Black's opinion for the Court in the Youngstown case. See Youngstown Sheet \& Tube Co. v. Sawyer, 343 U.S. 579, 58589 (1952) (denying that the President has lawmaking authority, even in a matter affecting foreign affairs). However, because Justice Black did not develop a comprehensive theory of the 
The foregoing allocation suggests the appropriate resolution of the debate over executive agreements. ${ }^{126}$ Since international agreements other than treaties are contemplated by the Constitution but are not allocated to a particular branch, they are part of the President's residual foreign affairs power. This power, however, is limited in three respects. First, the President's power to make international agreements cannot extend to agreements that are properly classified as treaties, since that power was given jointly to the President and Senate by the plain words of the Constitution. ${ }^{127}$ Second, the President has no right to funds to implement executive agreements; that is a matter for Congress to decide through the normal legislative process. Third, contrary to some court decisions of the last century, the President's executive agreements cannot have the force of law, else the President would have a power greater than the English monarch's executive power. In other words, Congress must enact legislation to make executive agreements the law of the land. ${ }^{128}$

Finally, consider the question of treaty termination. In international law, treaties may be terminated by their own terms - that is, the treaty itself

President's foreign affairs powers, he was open to the criticism of the concurrences, by Justices Jackson and Frankfurter, that the President had broad and ill-defined powers over foreign affairs that might, in some circumstances, support lawmaking authority. Id. We think our theory shows why Justice Black was right to reject categorically the President's claims in Youngstown: The President does indeed have broad powers over foreign affairs, but lawmaking authority is not one of them.

We do not mean to suggest that the President's actions will never have an effect within the legal system. For example, the President's decision, pursuant to the Presidenl's foreign affairs powers, to recognize a foreign government may give that government the right to sue in U.S. courts, because U.S. courts have adopted a rule of decision that only recognized governments may sue. This, however, is no different from saying that the President's decision to appoint a person as an executive officer may give that person some immunity from suit because U.S. courts recognize some official immunity for executive officers. In each case, the President makes a decision as to status, but does not make a decision as to the appropriate rule of law. Other parties choose to give legal effects to presidential policies. In contrast, we find much more troubling the practice, followed in the mid-twentieth century, of U.S. courts according sovereign immunity to foreign states if, and only if, the President, on a case-by-case basis, declared that immunity should be accorded. See MARK W. JANIS, AN INTRODUCTION to InTERnATIONAL LAW 353 (3d ed. 1999). In these cases it seems that the President, not the courts, is creating the rule of decision regarding immunity, which appears tantamount to executive lawmaking. We note that this was not a practice followed at any time near the Founding. See Schooner Exch. v. McFaddon, 11 U.S. ( 7 Cranch) $116(1812)$.

126. For an expansion of this argument, see Ramsey, supra note 3.

127. See U.S. CONST. art. II, $\$ 2$. For an attempt to identify the distinction between treaties and other international agreements, see Ramsey, supra note 3, at 183-206.

128. Clark, supra note 70, at 1444-51; Ramsey, supra note 3, at 218-35. The passport power also proves relatively straightforward. Issuing (or denying) a passport is a foreign affairs power of the traditional chief executive not mentioned in the Constitution and (at least in the eighteenth century) having no legal effect within the U.S. system. HUNT, supra note 63, at 3-5. Thus, it lies with the President. Congress, of course, can legislate in support of this power by, for example, giving the President a bureaucracy to implement it, prohibiting state exercise of the power, and providing legal penalties for, as an example, forging passports. In short, the historical system of the President issuing passports and Congress legislating in support of this power has a sound constitutional basis. 
may provide for termination, for example, by notice and the elapse of a specified amount of time-and they may be terminated by the occurrence of certain events, for example, changed circumstances or a material breach by one side, coupled with notice of termination. ${ }^{129}$ Under U.S. constitutional law, the question is which branch has the power to make the requisite determinations and to direct the delivery of the appropriate notice. Although this question has greatly troubled foreign affairs scholarship, ${ }^{130}$ our framework yields a clear answer. Terminating a treaty in accordance with its express terms or with international law is a power not mentioned directly in the Constitution, but was obviously part of the traditional executive's foreign affairs power. ${ }^{131}$ Under our theory, such powers lie with the President. In our view, therefore, President Carter acted with full constitutional authority in the events giving rise to Goldwater v. Carter. ${ }^{132}$ Rather than viewing that case as an insoluble foreign policy dilemma on which the Constitution is silent, ${ }^{133}$ or as an example of presidential usurpation of a congressional prerogative, ${ }^{134}$ we think it a relatively straightforward example of the exercise of the residual executive power over foreign affairs. ${ }^{135}$

\section{The Executive Power in Eighteenth-Century Political Theory}

In the previous Part, we introduced our claim that the President enjoys residual foreign affairs authority by virtue of the executive power. Here we begin to document our central assertion that executive power had a distinct

129. JANIS, supra note 125 , at $36-40$; see also Vienna Convention on the Law of Treaties, May 23, 1969, arts. 62-63, 1155 U.N.T.S. 336, 346-47 (listing grounds for termination of treaties).

130. See supra Section I.B.

131. We view these two instances as exercises of essentially the same power-giving notice of termination of a treaty in accordance with its terms. In the one case the termination terms are explicit; in the other, the terms are part of the background understanding upon which the treaty is drafted. In either case, however, the parties understand that the treaty may be terminated upon the occurrence of certain events and the giving of notice, and the constitutional question is which branch may decide to give the notice. Congress, of course, can pass a statute inconsistent with a provision of a treaty or with an entire treaty, so long as the subject matter is within Congress's enumerated powers; however, that is not the same as terminating the treaty, which, among other things, generally requires notice to the other party.

132. 444 U.S. 996 (1979). Similarly, we disagree with Professor Ackerman's suggestion that President Bush lacks the constitutional authority to terminate the Anti-Ballistic Missile Treaty See Ackerman, supra note 76.

133. See ADLER, supra note 78, at 248-340.

134. See Ackerman, supra note 76.

135. A more difficult question is whether the President may declare a treaty terminated where a treaty does not provide (either explicitly or implicitly) that it is terminable. This was plainly a power contained within the English monarch's executive power, so one might think that the President also has this power. On the other hand, in this circumstance the President would be acting contrary to the law as reflected in the treaty. It is not clear what effect the combination of the Supremacy Clause of Article VI and the Take Care Clause of Article II, Section 2 would have on this analysis. We think this a sufficiently difficult question to place it beyond the scope of this Article. 
foreign affairs component. As the evidence we adduce below demonstrates, prominent eighteenth-century political theorists confirmed that one attribute of the executive power was the authority to direct a nation's external relations. These theorists were well known to the members of the Philadelphia Convention and their definitions and discussions were highly valued resources for the Founding generation.

It goes without saying that the phrase "executive power" encompassed different types of powers through the ages. William Gwyn, the preeminent historian of the separation of powers of the 1650 to 1750 era, writes that during that period, the executive power consisted of the present-day categories of executive power and judicial power. ${ }^{136}$ Both of these subcategories involved law execution, the quintessential executive function. ${ }^{137}$ Of course, we wish to reveal an alternative sense of executive power-a foreign affairs sense. The writings of John Locke, Baron de Montesquieu, and William Blackstone, among others, reveal this secondary meaning of executive power and also disclose the gradual enlargement of executive power beyond its traditional law enforcement sphere.

Penned in the late seventeenth century, John Locke's Second Treatise of Government hastened the process by which executive power took on its foreign affairs component. ${ }^{138}$ By confirming the close and necessary relationship between the executive and "federative" powers-i.e., the law execution power and the foreign affairs power-Locke laid the groundwork for Montesquieu, Blackstone, and others who confirmed that the federative power was an integral branch of the executive power.

Just as he did with the law-execution power, Locke traced the federative power to his celebrated state of nature. According to Locke, in the state of nature each individual had the "natural" power of interacting with other individuals. When individuals created civil society, however, things stood differently. Individuals still arranged their relationships within a particular civil society. The government, however, assumed the federative power. Locke defined that power as including authority over "war and

136. W.B. GWYN, The MEANing OF THE Separation OF POWERS 5 (1965); see also FRANCIS D. WORMUTH, THE ORIGINS OF MODERN CONSTITUTIONALISM 61-62 (1949) (making the same observation). But see M.J.C. VILE, CONSTITUTIONALISM AND THE SEPARATION of POWERS 31-32 (2d ed. 1998) (arguing that the executive power discussed during the period really only encompassed the judiciary, not the executive law enforcement machinery known to us today).

137. See Prakash, supra note 2.

138. See VILE, supra note 136, at 66. Vile notes that the Reverend George Lawson had previously observed that the executive power had external and internal components. Id. at 62 (quoting George Lawson, an EXamination of the POltTical PaRT of Mr. HobBs His LEVIATHAN 8 (1657)). Lawson noted that "[o]ne and the same sword must protect from enemies without and unjust subjects within. For the sword of war and justice are but one sword." Id. Professor Harvey Mansfield traces the foreign affairs component of executive power even earlier, to the sixteenth-century writings of Niccolo Machiavelli. HARVEY C. MANSFIELD, JR., TAMiNG THE PRINCE 135-36 (1989). 
peace, leagues, and alliances, and all the Transactions with all Persons and Communities" outside of the state. ${ }^{139}$ Because the state enjoyed the federative power, it acted on behalf of civil society in international affairs, and any injury done to a member of the society by outsiders was regarded as an injury to the society as a whole. ${ }^{140}$

Where did the federative power rest? With whoever wielded the executive power. Although the two powers were distinct in Locke's treatment-the executive power consisted of executing the municipal laws within society and the federative power related to the management of the security and interests of the public outside the society-the two powers, he said, "are always almost united." 141 Indeed, they "are hardly to be separated, and placed... in the hands of distinct Persons" because both require the command of the "force of the Society." 142 To vest these distinct but related authorities in independent hands would be impracticable and would invite "disorder and ruine" because the "Force of the Publick" would be divided. ${ }^{143}$

Although the executive and federative powers were inevitably joined, Locke argued that they were subject to different constraints. For instance, the executive power's execution of the law could be restrained by standing law. In contrast, successful exercises of the federative power necessarily required discretion. As Locke put it, although the federative power was of great consequence, it should not be restrained by "antecedent, standing, positive Laws." ${ }^{144}$ After all, what should be done in relation to foreigners depends "upon their actions, and the variations of designs and interests" and thus cannot be delineated in advance. ${ }^{145}$ Hence, those who enjoyed the federative power must prudently and wisely employ their discretion for the benefit of society. ${ }^{146}$

Nonetheless, although Locke distinguished the two powers (and their constraints), they were always lodged together. As M.J.C. Vile put it, Locke's federative/executive distinction was "one of function only." 147 Indeed, perhaps in recognition of the extremely close relationship between the powers, Locke sometimes used executive power interchangeably with the federative power. For instance, at one point he observed that the executive power determines "how far Injuries from without [society] are to

139. John Locke, Two Treatises of Government 383 (Peter Laslett ed., Cambridge Univ. Press 1963) (1690).

140. Id.

141. Id

142. Id. at 384 .

143. Id.

144. Id. at 383-84.

145. Id. at 384 .

146. Id.

147. VILE, supra note 136 , at 66 . 
be vindicated." ${ }^{148}$ Although the powers were distinct as a theoretical matter, Locke could cite the powers interchangeably, because he had stated that they were inseparable.

The influential Charles Louis de Secondat, Baron de Montesquieu, confirmed that Locke's federative power had become a branch of the executive power by the mid-eighteenth century. Unlike his predecessor, Montesquieu unequivocally classified both functions as branches of the executive power. Indeed, the federative power did not make its way into his taxonomy: "In every government there are three sorts of power: the legislative, the executive, in respect to things dependent on the law of nations; and the executive, in regard to things that depend on the civil law." ${ }^{149}$ Montesquieu immediately provided a more precise definition of the executive power over foreign affairs: making war and peace, sending or receiving embassies, establishing public security, and protecting against invasions. ${ }^{150}$ Although Montesquieu subsequently paid far more attention to the domestic law-execution component of the executive power, he returned to the external executive power when considering the Roman Republic. ${ }^{151}$ Montesquieu thus helped usher in the late eighteenth-century view that the executive power had domestic and foreign affairs components. ${ }^{152}$ Gwyn goes so far as to claim that in Montesquieu's time, the "executive branch of government [was considered] as being concerned nearly entirely with foreign affairs." 153

William Blackstone's treatment of separation of powers owed an unmistakable debt to Montesquieu. ${ }^{154}$ Not surprisingly, the Vinerian Professor of Law at Oxford also described the foreign affairs authority as an executive endowment. Early in his influential Commentaries on the Laws of England, Blackstone noted that " $[\mathrm{t}] \mathrm{he}$ supreme executive power of these kingdoms is vested by our laws in a single person." 155 "He began his enumeration of those prerogatives, "the exertion whereof consists the

148. LOCKE, supra note 139, at 343; see also id. at 371 (referencing executive power as the authority to prevent or redress foreign injuries and to secure society from invasions).

149. BARON DE MONTESQUiEU, ThE SPIRIT OF LAwS 185 (Thomas Nugent trans., Classics of Liberty Library 1994) (1751).

150. $l d$.

151. Id. at 212-13 (claiming that the Roman senators had executive power and thus "were the arbiters of the affairs of the allies; they determined war or peace, and directed in this respect the consuls ... they ... . received and sent embassies" and declared who were the allies of the Roman Republic).

152. According to Gwyn, Montesquieu thought that the conduct of foreign relations was executive in nature because foreign relations involved the execution of the law of nations. GwYN, supra note 136, at 101 n.3.

153. See id. at $103 \& \mathrm{n} .2$.

154. VILE, supra note 136, at 111-12.

155. 1 WRliam BlackStONe, COMMENTARIES $* 183$. 
executive part of government," ${ }^{56}$ with a discussion of "foreign concerns." 157 Blackstone proceeded to enumerate the King's foreign affairs authority: $\mathrm{He}$ "has the sole power of sending embassadors to foreign states, and receiving embassadors at home"; 158 he may "make treaties, leagues, and alliances with foreign states and princes"; ${ }^{159}$ he has "the sole prerogative of making war and peace"; $;{ }^{160}$ and he has the power of issuing letters of marque and reprisal when his subjects have suffered some depredation at the hands of a foreign country and have not received satisfaction. ${ }^{161}$

According to Blackstone, the executive power "is the delegate or representative of his people" who transacts with "another community" because it is impossible for individuals of one community to transact directly "the affairs of that state" with another. ${ }^{162}$ Had there not been a foreign relations monopoly in the hands of the Crown, foreign relations would suffer a debilitating disunity. Many people means many wills; many wills means inconsistency, feebleness, and paralysis. Hence " [w] hat is done by the royal authority, with regard to foreign powers, is the act of the whole nation: what is done without the king's concurrence is the act only of private men." 163

In addition to the celebrated Locke, Montesquieu, and Blackstone, other prominent eighteenth-century writers identified foreign affairs power as executive power. Thomas Rutherforth, a leading English commentator on the law of nations, wrote that although the primary function of the executive was law enforcement,

[t]he second branch of executive power, which is called external executive power... is the power of acting with the common strength or joynt force of the society to guard against such injuries, as threaten it from without; to obtain amends for the damages arising from such injuries; or to inflict punishment upon the authors and abettors of them. ${ }^{164}$

156. $1 \mathrm{id}$. at $* 242$; see also $1 \mathrm{id}$. at $* 233$ (claiming that the executive's prerogatives are necessary to "maintain the executive power in due independence and vigour").

157. 1 id. at $* 245$.

158. Id.

159. 1 id. at $* 249$.

160. Id.

161. $1 \mathrm{id}$. at $* 250$. Blackstone also mentions a number of foreign affairs prerogatives that relate to aliens. The King could send aliens home whenever he saw fit; he could grant "safe conduct" to aliens from hostile nations, $1 \mathrm{id}$. at *251, and he could make a "denizen" out of an alien, 1 id. at $* 362$. (A denizen occupied an intermediate position between an alien and a naturalized citizen. 1 id. at *362.)

162. $1 \mathrm{id}$. at $* 245$.

163. Id.

164. THOMAS RUTHERFORTH, INSTITUTES OF NATURAL LAW bk. II, ch. III, at 54 (n.p. 1754). 
Rutherforth evidently had war power principally in mind, but he included in this category powers of peace, truce, negotiation, and "the power of adjusting the rights of the society in respect of foreigners." Thus, he concluded that:

[W] hen we are speaking of external executive power, we are supposed to include under that head, not only what is properly called military power, but the power likewise of making war or peace, the power of engaging alliances for an encrease of strength, either to carry on war or to secure peace, the power of entering into treaties, and of making leagues to restore peace ... and the power of adjusting the rights of a nation in respect of navigation, trade, etc. .... ${ }^{165}$

Rutherforth also said that ambassadors are part of "the rest of that branch of the executive power, which is external" and thus ambassadors are "under the regulation of the executive, as to the degree or extent of their power." 166

Similarly, Emmerich de Vattel, a leading European writer on the law of nations, said that the "conductor" or "sovereign" of a nation had the "executive power" and consequently could enter into treaties, send emissaries, engage in war, and control the nation's ambassadors. ${ }^{167}$ Jean De Lolme, a European admirer of the English Constitution like Montesquieu, described the King's executive power as including the ability to serve as "the representative and depository of all the power and collective majesty of the nation; he sends and receives ambassadors; he contracts alliances; and has the prerogative of declaring war, and of making peace." 168

165. Id.

166. Id. at 55-61. Rutherforth added that, although all these powers were properly classified under the same heading-external executive power-they need not all be in the same hands, and some could be assigned to the legislature. He also emphasized legislative checks upon the exercise of executive power: "[E]xtemal executive power, in its own nature, is no more an independent power of acting without being controlled by the legislative, than the internal executive power is." ld. at 58. This is so, he said, because it is subject to legislative checks such as raising armies, regulating and paying armies, and enforcing treaties. These powers " are planely natural checks of the legislative power upon the executive, and are sufficient to shew, that the latter is not a discretionary power but is in itself under the control of the former." Id. at 58-59.

167. E. DE VATtEl, THE Law OF Nations OR THE PRINCIPles OF NATURAL Law 69, 100 , 160-61, 235-36, 393 (photo. reprint 1993) (Charles G. Fenwick trans., Carnegie Inst. 1916) (1758). But see id. at 100, 235-36 (observing that a nation must choose to confer foreign affairs authority on the executive and that occasionally some foreign affairs powers-such as warmaking-are placed elsewhere).

168. J.L. DE LOLME, THE CONSTITUTION OF ENGLAND 50 (photo, reprint 1999) (London, A. Hancock 1821). Other leading theorists of the law of nations discussed foreign affairs authority that resided with the King or the sovereign without explicitly tying that authority back to the phrase "executive power." E.g., 2 JEAN JACQUES BURLAMAQUI, THE PRINCIPLES OF NATURAL AND POLITIC LAw 53, 155-56, 216 (Thomas Nugent trans., Amo Press 1972) (1807) (discussing the foreign affairs powers of the sovereign). 
These authorities were widely known, read, and cited in eighteenthcentury America. Bernard Bailyn, perhaps the leading scholar of eighteenth-century American political thought, says that:

The ideas and writings of the leading secular thinkers of the European Enlightenment... were quoted everywhere in the colonies, by everyone who claimed a broad awareness. In pamphlet after pamphlet the American writers cited Locke on natural rights and on the social and governmental contract, Montesquieu and later De Lolme on the character of British liberty and on the institutional requirements for its attainment, ... and Vattel on the laws of nature and of nations, and on the principles of civil government. ${ }^{169}$

Bailyn adds that Blackstone's Commentaries was a "standard authorit[y]" in the legal field. ${ }^{170}$ Historian Charles Lofgren lists Rutherforth and Vattel among the writers on the law of nations consulted by eighteenth-century Americans. ${ }^{171}$ References to Locke, Montesquieu, and Blackstone are particularly common in the Constitution's drafting ${ }^{172}$ and ratifying history. ${ }^{173}$

Thus, as the Framers set about drafting and ratifying the Constitution, the leading political writers they consulted confirmed that the executive power had a foreign affairs component. Locke had observed that, because both the executive and federative powers required the use of a nation's

169. BernaRd BAILYN, THE IdEOLOGICAL ORIGINS OF THE AMERICAN REVOLUTION 27 (1967); see also Jack N. Rakove, Fidelity Through History (or to It), 65 FordHAM L. REV. 1587, 1598 (1997) (listing De Lolme, along with Locke, Montesquieu, and others, as important sources during the constitutional period).

170. BAlLYN, supra note 169 , at 31 .

171. Charles A. Lofgren, War-Making Under the Constitution: The Original Understanding, 81 YALE L.J. 672, 689 (1972). Although Lofgren ranks Rutherforth somewhat behind Vattel and other writers such as Grotius and Burlamaqui in terms of influence, he notes, among other references, that "Luther Martin read portions of Rutherforth to the Constitutional Convention ... ; Hamilton quoted Rutherforth in Federalist 84; and James Wilson cited Rutherforth in his 1790-91 law lectures." Id. at 689 n.78.

172. E.g., I THE RECORDS OF THE FEDERAL CONVENTION OF 1787, at 437 (Max Farrand ed., 1966) (statement of Luther Martin) (citing Locke's view of the state of nature); 1 id. at 71,391 (citing Montesquieu); 2 id. at 34 (same); 1 id. at 472 (citing Blackstone); 2 id. at 448 (same).

173. E.g., 2 The Debates In the Several State Conventions on the Adoption of the FEDERAL CONSTITUTION AS RECOMMENDED bY THE GENERAL CONVENTION AT PHILADELPHia IN 1787, at 540 (Jonathan Elliot ed., William S. Hein \& Co. 2d ed. 1996) (1891) [hereinafter ELLIOT'S DEBATES] (comments of Thomas M'Kean at the Pennsylvania ratifying convention) (citing Locke to defend the proposed Constitution); 3 id. at 294 (comments of Edmund Pendleton at the Virginia ratifying convention) (citing Locke to defend the Constitution); $2 \mathrm{id}$. at 14-17, 12628 (comments of various speakers at the Massachusetts ratifying convention) (citing Montesquieu); 4 id. at 278 (comments of Charles Cotesworth Pinckney at the South Carolina ratifying convention) (citing Blackstone to defend the supremacy of federal treaties); $4 \mathrm{id}$. at 63 (comments of William Maclaine at the North Carolina ratifying convention) (citing Blackstone); THE FEDERALIST Nos. 43, 47 (James Madison) (citing Montesquieu); THE FEDERALIST Nos. 9, 78 (Alexander Hamilton) (citing Montesquieu); THE FEDERALIST NOS. 69, 84 (Alexander Hamilton) (citing Blackstone). 
armed forces, the two powers always rested in the same hands. Although Montesquieu and Rutherforth abandoned Locke's category of federative power, their taxonomy of governmental powers was largely consistent with Locke's. What was formerly the federative power was now known as the "external executive power" or the executive power "dependent on the law of nations." In addressing the English Crown's executive prerogatives, Blackstone and De Lolme confirmed the expansion of executive power to include foreign affairs. Given the theorists' notorious usage, it is hardly surprising that subsequent Americans would continue to refer to the control of external relations as an aspect of the executive power, ${ }^{174}$ the political theorists just wrote more systematically about the meaning of a term that was well understood by the Framers, much like a dictionary might supply a more fulsome definition of a term whose meaning can be discerned from everyday conversations.

Advocates of congressional supremacy in foreign affairs have tended to ignore or downplay the significance of the political writers' taxonomy. Yet these thinkers established the theoretical baseline for the Constitution's allocation of foreign affairs power. We cannot underestimate the significance of the fact that these thinkers regarded foreign affairs as an aspect of executive power, nor can we ignore the fact that no one has been able to cite any eighteenth-century theorist who described foreign affairs as a legislative power. To be sure, the Framers did not embrace the idea that all foreign affairs powers should be vested in the executive, and, as we discuss below, they crafted particular constitutional language to avoid this result. But they understood-as anyone reading Blackstone, Locke, Montesquieu, and other eighteenth-century writers would have understood-that the phrase "executive power" would include foreign affairs powers unless otherwise qualified by particular language.

\section{The EXECUTIVE POWER OVER Foreign AFFaIRS OF THE CONTINENTAL CONGRESS}

In the previous Part, we recounted how prominent political theorists included a distinct foreign affairs component in the executive power. In this Part, we consider the executive power over foreign affairs at the national level prior to the Constitution's drafting and adoption. Three points bear emphasizing. First, Congress assumed control of foreign affairs. Second, adopting the political theorists' definitions, many (including Congress itself) understood that the control of foreign affairs was an executive power. Finally, some statesmen (such as the Secretary for Foreign Affairs) thought

174. Of course, more often they referenced the essential law-execution sense of executive power. 
that Congress, as a multimember body, was not up to the task of exercising the executive power over foreign affairs. Congress could not keep secrets; it could not act expeditiously; it could not pursue a consistent policy; and, because it had a plural, changing membership, it could not be held accountable for its many executive failings. These concerns set the stage for a transfer of executive power (including executive foreign affairs power) to a single executive.

From 1774 on, the Continental Congress slowly assumed foreign affairs authority, first by assuming control of diplomacy with Britain ${ }^{175}$ and second by establishing contacts with potential foreign allies. ${ }^{176}$ By 1776 , Congress was exercising the executive power of foreign relations "in the same manner as did all eighteenth-century powers." "I77 In so lodging foreign affairs authority, the nation was likely reacting to the perceived wrongs committed by the English executive. Rather than creating a powerful, unitary executive charged with foreign affairs authority, the nation created a deliberative, heavily constrained, plural executive-the Continental Congress.

Even in the earliest days, however, delegates discovered that a deliberative body was an ineffective and lame executive. Initially, Congress acted through a committee of the whole or by ad hoc committees. ${ }^{178}$ Quickly, Congress moved to standing committees to tend to specified tasks. ${ }^{179}$ However, these standing committees proved problematic. Although the committees were enduring, the membership was not. Delegates came and went, and many did not attend their committee meetings. ${ }^{180}$ As a result, the committees proceeded so glacially that Congress was the butt of jokes for its sluggish ways. ${ }^{181}$

To some, the solution was obvious. Congress must establish executive departments (war, treasury, etc.) and create executive officers not part of Congress to superintend these departments. According to Samuel Chase, Congress was not fit to "act as a Council of War" because it was too large, slow, and indiscreet. Robert Morris (the future "financier" of the Revolution) observed that "mismanagem[en]t" was to be expected because

175. See JeRril yn GReene MARSTON, KING ANd CONGRESS 207-15 (1987).

176. Id. at 219-23.

177. Id. at 223. Interestingly, although Congress assumed forcign affairs control by 1776 , the Declaration of Independence, written in the same year, asserted that the "Free and Independent States" had "full Power to levy War, conclude Peace, contract Alliances, establish Commerce, and to do all other Acts and Things which Independent states may of right do." THE DECLARATION OF INDEPENDENCE para. 23 (U.S. 1776). Thus, while the Declaration suggested that each state could exercise the executive power over foreign affairs, in practice, Congress assumed the dominant role on behalf of all thirteen states.

178. MARSTON, supra note 175 , at 305.

179. Id.

180. Id at 305-06.

181. Id. at 306 . 
"no Men living can attend the daily deliberations of Congress \& do executive parts of business at the same time." So long as Congress attempted "to execute as well as deliberate on their business it never will be done as it ought." 182

Although there was some movement in 1776 to delegate some of Congress's "executive business" to separate boards composed of gentlemen who were not delegates, ${ }^{183}$ Congress did not follow through on this sound impulse until 1781. In January of that year, Congress finally created a Department of Foreign Affairs superintended by a Secretary. ${ }^{184}$ In February, Congress completed the executive reorganization when it erected "civil executive departments"-Treasury, Marine, and War-and created a Superintendent of Finance and Secretaries of Marine and War. ${ }^{185}$

In the newly established Department of Foreign Affairs, the Secretary for Foreign Affairs was but a "congressional clerk." $186 \mathrm{He}$ was to communicate with American envoys and with foreign envoys to America "for the purpose of obtaining more extensive and useful information relative to foreign affairs, to be laid before Congress when required"; to transmit congressional messages to American envoys and foreign courts; to preserve the Department's books and records; and to receive and report to Congress applications of foreigners. ${ }^{187}$ The Secretary was a creature of Congress, ${ }^{188}$ which was natural given that Congress enjoyed the executive power over foreign affairs.

182. Id. at 307 (alteration in original). Jennings B. Sanders lists other problems with committees' conduct of foreign relations. JENNINGS B. SANDERS, EVOLUTION OF EXECUTIVE DEPARTMENTS OF THE CONTINENTAL CONGRESS 1774-1789, at 40-41 (1935) (listing lack of secrecy, communications difficulties, and factionalism).

183. 6 JOURNALS OF THE CONTINENTAL CONGRESS, 1774-1789, at 1041 (Wonthington Chauncey Ford ed., 1910).

184. 19 JouRnals OF THE CONTINENTAL CONGRESS, 1774-1789, at 43-44 (Gaillard Hunt ed., 1912). Although the resolution did not state that the Foreign Affairs Department was an executive department, subsequent resolutions and debates make this clear.

185. $19 \mathrm{id}$. at 125-26. Subsequent resolutions referred to these departments as "executive departments." For instance, on November 12, 1782, Congress tabled a resolution that provided "[ $t]$ hat when a matter is referred by Congress to any of the Executive Departments, to take order, it is the sense and intention of Congress that the measure referred to such department be carried into execution." 23 JOURNALS OF THE CONTINENTAL CONGRESS, 1774-1789, at 722 (Gaillard Hunt ed., 1914). Later, when Congress considered creating a Home Secretary, the proposed resolution referred to "executive departments" who would, on occasion, respond to relevant correspondence. 28 Journals of tHE CONTINENTAL CONGRESS, 1774-1789, at 213 (John C. Fitzpatrick ed., 1933).

186. Elmer Plischke, U.S. Department of STATE II (1999); see also Jay Caesar Guggenheimer, The Development of the Executive Departments, 1775-1789, in ESSAYS IN THE CONSTITUTIONAL History OF THE UNITEd STATES IN THE FoRMative PERIOD 1775-1789, at 116, 163 (J. Franklin Jameson ed., Houghton, Mifflin \& Co. 1986) (1889) (describing the Secretary as being treated as but a "congressional clerk"). But see HENRY BARRETT LEARNED, THE PRESIDENT' S CABINET 58 (1912) (assuming that Secretary John Jay was the "chief executive of the Confederation").

187. 19 JOURNALS OF THE CONTINENTAL CONGRESS, 1774-1789, supra note 184 , at 43-44.

188. Subsequently, Congress cmphasized the subservient nature of the Secretary by altering his title. In February 1782, Congress changed the title to "Secretary to the United States of 
The long-awaited ratification of the Articles of Confederation on March 1, 1781, validated Congress's executive exertions. Although the Articles did not expressly vest Congress with the "executive power," the Articles conveyed that power to Congress nonetheless. Under Article IX, Congress had "the sole and exclusive right[s]" of "determining on peace and war," of sending and receiving ambassadors, of entering into treaties and alliances, of establishing rules for captures, and of granting letters of marque and reprisal in times of peace. ${ }^{189}$ Pursuant to the same Article, Congress could appoint " committees and civil officers as may be necessary for managing the general affairs of the united states under [Congress's] direction." ${ }^{190}$ Congress finally had textual authority for its exercise of the executive power. ${ }^{191}$

That the Department of Foreign Affairs was necessarily executive in nature and that Congress enjoyed the executive power over foreign affairs are clear from various sources. For instance, a committee report regarded the Department of Foreign Affairs as one of "the four great executive Civil Departments." 192 Another committee felt it unnecessary to consider the Secretary for Foreign Affairs's rank "relative to other heads of the Executive Departments" because another committee was considering the

America, for the Department of Foreign Affairs." 22 JOURnals of the CONTINENTAL CONGRESS, 1774-1789, at 88 (Gaillard Hunt ed., 1914). The subtle change made clear that the Secretary toiled for Congress.

189. ARTICLES OF CONFEDERATION art. IX, para. 1. In truth, these were not strictly exclusive rights because Congress could permit the states to send and receive embassies and to enter into conferences, agreements, alliances, and treaties. Id. art. XI, paras. 1-2.

190. Id. art. IX, para. 5.

191. We admit that the drafters of the Articles did not employ the most economical phrasing. After all, the Articles could have declared that Congress enjoyed the "executive power." Nevertheless, given the fact that athers understood Congress as enjoying the executive power over foreign affairs, see infra notes 192-208 and accompanying text, we do not view the Articles as implicitly rejecting the notion that foreign affairs was an executive power.

If the Continental Congress enjoyed complete authority over foreign affairs notwithstanding that the Articles did not use the phrase "executive power," one might conclude that the Constitution also completely allocates foreign affairs powers to Congress. After all, Congress retained most of the powers ascribed to the Continental Congress. If the former allocation was sufficient, why not the latter?

Such an argument overlooks the fact that the Continental Congress also had the authority to "manag[e] the general affairs of the United States," the power to make peace, and the power to send and receive ambassadors. See supra note 190 and accompanying text. Because our Congress clearly lacks these powers, particularly the power to manage the United States's general affairs, we do not believe that it is proper to conclude that Congress enjoys the complete foreign affairs powers that the Continental Congress had. Just as important, the shorthand often used to describe Congress's foreign affairs powers-the executive power-was conveyed to the President by the Constitution. Hence, under our view the President enjoys the residual executive power over foreign affairs - the nation's general affairs-that was formerly vested with the Continental Congress.

192. I9 JOURNALS OF THE CONTINENTAL CONGRESS, 1774-1789, supra note 184, at 169. 
same. ${ }^{193}$ Private correspondence of delegates also clearly marked the Department (along with the others created in 1781) as executive. ${ }^{194}$

Furthermore, the executives themselves understood their departments' status. The first Secretary to the United States for the Department of Foreign Affairs, Robert Livingston, understood that the Department was executive. ${ }^{195}$ His successor, John Jay, also recognized that he toiled in an executive department. ${ }^{196}$ Likewise, when President Washington assumed the reins of the executive branch, he signaled his identical understanding of the Department's executive nature by requesting Jay's opinion regarding the present state of foreign affairs. ${ }^{197}$ There can be no doubt that the Department of Foreign Affairs was regarded as an executive department.

Evidence also confirms that Congress was understood as enjoying the executive power over foreign affairs. For instance, the famous Essex Result of 1778 declared the obvious when it observed that the "confederation of the United States of America hath lopped off [the external] branch of the executive, and placed it in Congress." ${ }^{198}$ Following the footsteps of Locke, Montesquieu, and Rutherforth, the Result noted that the "external" executive power consisted of war, peace, sending and receiving ambassadors, and everything else concerning transactions between America and other independent states. ${ }^{199}$ Likewise, Lord Hawke, speaking on the 1783 peace treaty in the House of Lords, noted that the Continental Congress only had the "executive power" where the treaty was concerned

193. See 24 Journals OF THE CONTINENTAL CONGRESS, 1774-1789, at 335 (Gaillard Hunt ed., 1922) (emphasis added).

194. See Letter from the Connecticut Delegates to Jonathan Trumbull, Governor of Connecticut (Feb. 9, 1781), in 5 LETTERS OF MEMBERS OF THE CONTINENTAL CONGRESS 565, 565-66 (Edmund C. Burnett ed., Peter Smith 1963) (1931) ("Congress have newly arranged their Executive departments and established the following offices (viz) Minister of Foreign Affairs ...."); Letter from James Duane to George Washington (Jan. 29, 1781), in 5 LETTERS OF MEMBERS OF THE CONTINENTAL CONGRESS, supra, at 551, 551 (noting that Congress was about to create "Executives or Ministers" in the departments of Finance, Foreign Affairs, and others).

195. Letter from Robert R. Livingston to Benjamin Franklin (Oct. 20, 1787), in 1 THE EMERGING NATION 257 (Mary A. Guinta et al, eds., 1996).

196. See Letter from John Jay to the President of Congress (Sept. 2, 1785), in 29 JournaLS OF THE CONTINENTAL CONGRESS, 1774-1789, at 679-80 (John C. Fitzpatrick ed., 1933) (observing that principal executive officers should be able to instruct the post office regarding mail in the context of a post office failure to deliver any mail from John Adams to Jay). Almost immediately, Congress gave Jay the authority to inspect mail at any post office. See 29 JOURNALS OF THE CONTINENTAL CONGRESS, 1774-1789, supra, at 685.

197. Letter from George Washington to John Jay (June 1789), in 3 THE CORRESPONDENCE AND PUBlic PAPERS OF JOHN JAY 369 (Henry P. Johnston ed., New York, G.P. Putnam's Sons 1891). Washington sought Jay's opinion notwithstanding "the present unsettled state of the Executive Departments under the Government of the Union." Id. Washington was referring to the fact that Congress had not yet created new executive departments to supplant the old executive institutions.

198. THEOPHILUS PARSONS, THE ESSEX RESULT (1778), reprinted in 1 AMERICAN POLITICAL WRITING DURING THE FOUNDING ERA 1760-1805, at 494 (Charles S. Hyneman \& Donald S. Lutz eds., 1983).

199. Id. 
and that it, like the English King, could only make "recommendations" to the state legislatures. In other words, because Congress was only executive in nature, it could make treaties, but it could not guarantee legislative conformity to them. ${ }^{200}$ Subsequent commentators also confirmed that the Continental Congress wielded the executive power. ${ }^{201}$

Given that contemporary usage clearly hewed to Montesquieu's and Blackstone's definition of executive power and that diverse observers acknowledged that Congress enjoyed the executive power and that its Department of Foreign Affairs was executive in nature, there can be little doubt that Congress possessed the executive power over foreign affairs. Although simple word association naturally conjures up "legislative" when one considers Congress, the Continental Congress also was an executive when it came to foreign affairs. ${ }^{202}$

Although Congress enjoyed the executive power, from the beginning statesmen criticized Congress as an ineffectual executive. Foreign affairs required secrecy, dispatch, and consistency, three qualities in short supply in a plural, fluctuating executive. The creation of the Department of Foreign Affairs and the Secretary hardly muted these criticisms. Indeed, one of the most fierce critics was the Secretary himself. In several letters, Jay bemoaned his master's inept exercise of executive power and repeatedly urged the adoption of a framework that would separate the executive, judicial, and legislative powers. To Thomas Jefferson, Jay wrote that Congress was ill-suited to managing foreign affairs because there were "unseasonable delays and successive obstacles in obtaining the decision and sentiments of Congress." ${ }^{203}$ In another letter to Jefferson, this time decrying the plight of American hostages, Jay pronounced Congress "unequal" to the task of superintending the executive power. ${ }^{204}$ Finally, in a

200. Letter from Thomas Jefferson to British Minister George Hammond (May 29, 1792), in 7 The WORKS OF ThOMAS JefFerson 3, 23 (Paul Leicester Ford ed., 1904). As noted infra notes 204-205, Jay himself spoke of Congress exercising the executive powcr.

201. For instance, the ratification debates confirm that under the Articles of Confederation, Congress wielded the executive power. See 9 THE DOCUMENTARY HISTORY OF THE Ratification of the Constitution 931, 986 (John P. Kaminski \& Gaspare J. Saladino eds., 1990) (comments of Governor Edmund Randolph before the Virginia ratifying convention); 2 id. at 469-74 (comments of James Wilson at the Pennsylvania ratifying convention); see also 8 id. at 262-67 (comments of Edmund Randolph) (complaining that under the Confederation, legislative and executive powers are combined); 2 ELLIOT'S DEBATES, supra note 173, at 90-91 (comments of Theophilus Parsons at the Massachusetts convention) (arguing to the same effect).

202. GuGGENHEIMER, supra note 186 (discussing the evolution of the executive departments); MARSTON, supra note 175, at 8,205 (describing Congress as primarily executive in nature); SANDERS, supra note 182 (making this clear by his very title-Evolution of Executive Depariments of the Continental Congress); Charles C. THACH, JR., THE CREATION OF THE PRESIDENCY 1775-1789, at 55-75 (Da Capo Press 1969) (1922) (discussing Congress's wielding of executive power in a chapter titled "National Executive Power").

203. Letter from John Jay to Thomas Jefferson (Aug. 18, 1786), in 3 THE CORRESPONDENCE AND PUBlic PaPers OF JOHN JaY, supra note 197, at 210, 210.

204. Letter from John Jay to Thomas Jefferson (Dec. 14, 1786), in 3 THE CORRESPONDENCE AND PUBliC PAPERS OF JOHN JAY, supra note 197, at 222, 223. 
letter to the former Commander in Chief, Jay lamented that Congress could not act with secrecy, dispatch, or responsibility. "The executive business of sovereignty, depending on so many wills" in Congress and moved by contradictory motives, would always be feebly done ${ }^{205}$ Having worked for a plural executive, Jay had an intimate and unparalleled insight into Congress's executive failings. This unique understanding explains his foursquare support for lodging the executive power in independent hands. But one hardly needed to be Secretary to the United States for the Department of Foreign Affairs to reach such conclusions. ${ }^{206}$ Contemporaries understood that Congress was ill-suited for executive tasks. ${ }^{207}$ And, once again, subsequent commentators confirmed that Congress had poorly superintended foreign affairs. ${ }^{208}$ Clearly, the foreign affairs regime was in need of a substantial overhaul.

The Articles period set the stage for a transfer of authority to a unitary executive who would provide the confidentiality, speed, and stability necessary for the general superintendence of foreign affairs. Although Congress would retain significant foreign affairs prerogatives, in large measure a unitary executive would direct the nation's foreign affairs. ${ }^{209}$

205. Letter from John Jay to George Washington (Jan. 7, 1787), in 3 THE CORRESPONDENCE AND PUBLIC PAPERS OF JOHN JAY, supra note 197, at 226, 227.

206. Indeed, before even assuming the role of Secretary, Jay had bemoaned Congress's inability to keep secrets. E.g., Letter from John Jay to George Washington (Apr. 26, 1779), in 3 The CorRespondence AND PUblic PAPERS OF JOHN JAY, supra note 197, at 209, 210 (observing that "there is as much intrigue in this State-house as in the Vatican, but as little secrecy as in a boarding-school").

207. Letter from Thomas Jefferson to Edward Carrington (Aug. 14, 1787), in 4 THE WRITINGS OF ThOMAS JefFerson 424 (Paul Leicester Ford ed., New York, G.P. Putnam's Sons 1894) (claiming that Congress had to separate its legislative and executive functions and that Congress was becoming enmeshed in executive details); Letter from George Washington to Henry Knox (Feb. 3, 1787), in GEORGE WASHINGTON, WRITINGS 634-35 (John Rhodehamel ed., 1997).

208. Although Congress possessed the "sole transaction of our affairs with foreign nations," THE FEDERALIST NO. 55, supra note 113, at 388 (James Madison), the "feebleness of our general government" led foreign regimes to "openly declare their unwillingness" to negotiate with the United States. Tench Coxe, An American: To the Members of the Virginia Convention, PA. GAZETTE, May 21, 1788, reprinted in 9 THE DOCUMENTARY HISTORY OF THE RATIFICATION OF THE CONSTITUTION, supra note 201, at 832,836 . James Madison also observed that navigational rights to the Mississippi would never be secured from Spain under the existing regime. 10 THE DOCUMENTARY HISTORY OF THE RATIFICATION OF THE CONSTITUTION, supra note 201, at 1225 (statement of James Madison at the Virginia convention). Succinctly cataloging the problems, Jay insisted that although Congress could make peace, it was "without power to see the terms of it observed." Congress could form alliances "but [was] without ability to comply with the stipulations on their part." Congress could form commercial treaties but lacked power "to inforce them at home or abroad." [JOHN JAY], AN ADDRESS TO THE PEOPLE OF THE STATE OF NEW

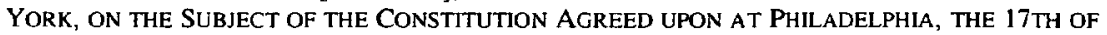
SEPTEMBER 1787 (1788), reprinted in 17 THE DOCUMENTARY HISTORY OF THE RATIFICATION OF THE CONSTITUTION, supra note 201, at 101, 109; see also Letter from George Thatcher to Pierse Long (Apr. 23, 1788), in 17 THE DOCUMENTARY HISTORY OF THE RATIFICATION OF THE CONSTITUTION, supra note 201, at 199, 200 (statement of George Thatcher, delegate to the Continental Congress from Massachusetts).

209. Although we believe that the executive power in the eighteenth century included a foreign affairs component, we have said nothing about the executive power over foreign affairs at 


\section{THE EXECUTIVE POWER OVER FOREIGN AFFAIRS AT THE PHILADELPHIA CONVENTION}

In the previous Parts, we established that the executive power had a foreign affairs component. Locke presaged this understanding, and Montesquieu, Blackstone, and others confirmed it. Second, we documented that from the Revolution to the eve of the Constitution, many declared that Congress enjoyed the executive power over foreign affairs and that its Department of Foreign Affairs was executive in nature. Third, we revealed that several statesmen (including Congress's Secretary for Foreign Affairs)

the state level. Some brief comments seem appropriate. For the most part, state constitutions said little specific about foreign affairs. The notable exceptions were the South Carolina Constitutions of 1776 and 1778. Article XXX of the 1776 constitution granted "executive authority" to the President, "limited and restrained as aforesaid." S.C. CONST. of 1776, art. XXX; see also S.C. CONST. of 1778, art. XI (analogous provision in the 1778 constitution). Article XXVI of the 1776 constitution supplied such a limitation when it noted that the President could not make war, peace, or final treaties without the consent of the general assembly and legislative council. S.C. CONST. of 1776, art. XXVI (providing "[t]hat the president and commander-in-chief shall have no power to make war or peace, or enter into any final treaty, without the consent of the general assembly and legislative council"); see also S.C. CONST. of 1778, art. XXXIII (analogous provision in the 1778 constitution). By writing such constitutions, South Carolinians confirmed that foreign affairs was one aspect of the executive authority. Rather than providing specific war, peace, and treaty authority to the executive and then limiting those powers, the constitutions granted "executive authority," partially subject to legislative consent.

In contrast, the Virginia Constitution made clear that the Virginia Governor lacked the executive power over foreign affairs. The constitution provided that the Governor, with the advice of a council, would "exercise the executive powers of government." VA. CONST. of 1776, para. 29. But the constitution went on to declare that the Governor "shall not, under any pretence, exercise any power or prerogative, by virtue of any law, statute or custom of England." Id. This language probably meant that the Governor lacked the executive power over foreign affairs. This reading is strengthened by comparing the Virginia Constitution to Jefferson's draft Virginia Constitution. Jefferson would have created an "Administrator" with "executive powers" to be exercised subject to a long list of constraints. Although the Administrator would "possess the power formerly held by the king," he would not enjoy the powers "of declaring war or concluding peace; of issuing letters of marque or reprisal[,] ... of laying embargoes, or prohibiting the exportation of any commodity for a longer space than [forty] days ... [or] of making denizens." Instead, such executive powers would be exercised by the legislature. THOMAS JEFFERSON, WRITINGS 340 (Merrill D. Peterson ed., 1984). The Virginia Constitution avoided the need to list all the executive prerogatives by simply declaring that the Governor would not enjoy the English King's prerogatives, save where the constitution specifically provided otherwise. The drafters of the Virginia Constitution and Jefferson both understood that executive power included foreign affairs authority, and that is why they included language designed to strip away foreign affairs authority.

Given the obvious foreign affairs component of South Carolina "executive authority," and given the need in Virginia to strip away foreign affairs authority from the cxccutive power, other state constitutions that referenced executive power (e.g., "supreme executive power and authority," N.Y. CONST. of 1777 , art. XVII) might have ceded foreign affairs authority to their respective chief executives as well. Indeed, in The Federalist No. 69, Hamilton suggested that in the absence of a federal treaty power, the treaty power might well devolve upon the state executives. THE FEDERALiST No. 69, supra note 113, at 400 (Alexander Hamilton). Although more research and a careful reading of the state constitutions would be necessary in order to reach firm conclusions, we presume that the ordinary understanding of executive power established by Locke, Montesquieu, and Blackstone should be used to construe the analogous phrases in state constitutions, absent some indication that the other constitutions followed Virginia's lead. 
regarded Congress as unfit to superintend foreign relations. A plodding, porous, and unstable plural executive was simply not an appropriate repository for the executive power over foreign affairs.

In this Part, we recount how the Philadelphia delegates reallocated the executive power over foreign affairs in response to the problems of the Articles era. The President would have sole authority in crucial foreign affairs subcategories, e.g., control of diplomatic instruments, control over international communications, and formulation of foreign policy. The President would share other executive authority with the partially executive Senate, e.g., appointment of ambassadors and treaty-making. Finally, Congress would continue to enjoy significant foreign relations powersforeign commerce, the law of nations, letters of marque and reprisal-but in a manner that virtually ensured some level of presidential influence. ${ }^{210}$ In other words, faced with the problems of the Articles era, the Philadelphia delegates did not swing from the extreme of a plural executive to the opposite extreme of vesting the entire executive power over foreign affairs in one person. Rather, they divided up executive power with an eye to ensuring that no one entity would dominate foreign affairs.

Each of the four major plans submitted to the delegates ${ }^{211}$ created a national executive. As might be expected, however, there were variations where foreign affairs was concerned. We briefly recount two of the plans, the Virginia Plan and the Hamilton Plan, because we believe that each had foreign affairs elements that are now part of the Constitution. Governor Edmund Randolph presented the so-called Virginia Plan, which, in addition to granting the executive the "general authority to execute the National laws," also ceded the "Executive rights vested in Congress by the Confederation." ${ }^{212}$ By providing that the national executive would enjoy Congress's "Executive rights," the Virginia Plan unambiguously vested the executive power over foreign affairs with the national executive. Alexander Hamilton's plan would have ceded less foreign affairs authority to the executive. In fact, his outline was quite similar to our actual foreign affairs Constitution. While his "Governor" would enjoy the "supreme Executive authority of the United States" and therefore would have the residual foreign affairs authorities not vested elsewhere, the Senate had advice and consent power over treaties and enjoyed the "sole Power to declare war." 213

210. Including, most prominently, the presidential veto.

211. The four plans were the Virginia Plan, the New Jersey Plan, the Hamilton Plan, and the Pinckney Plan.

212. 1 THE RECORDS OF THE FEDERAL CONVENTION OF 1787, supra note 172 , at 21 . By way of contrast, the new Congress would enjoy "the Legislative Rights vested in Congress by the Confederation." Id.

213. $1 \mathrm{id}$. at 292. 
Moreover, the Senate would wield influence over ambassadorial appointments by virtue of its advice and consent power. ${ }^{214}$

The Virginia Plan took center stage. Recall that it would have granted the executive the "Executive rights" of the Continental Congress. This aspect, although seemingly innocuous, came in for heavy criticism. Some delegates did not want an executive with all the imperial trappings of foreign affairs. When the Committee of the Whole first took up the Virginia Plan's executive powers, Charles Pinckney opposed ceding the "Executive powers of (the existing) Congress" because such powers "might extend to peace \& war \&c which would render the Executive a Monarchy." 2 is Pinckney's sentiments elicited some support. Pinckney's fellow South Carolinian, John Rutledge, remarked that although he supported a responsible, unitary executive, he also did not support vesting the "power of war and peace" in the executive. ${ }^{216}$ Likewise, James Wilson of Pennsylvania "did not consider the Prerogatives of the British Monarch as a

214. Id. Of all the plans, the New Jersey Plan seems to have envisioned the weakest executive and the only one bereft of foreign affairs authority. Unlike the Virginia Plan, the New Jersey Plan did not divide the Continental Congress's authority into legislative and executive powers and vest all of the former in a new executive. Rather, the new Congress was to enjoy all of Congress's existing powers. $1 \mathrm{id}$. at 243 . There were some notable exceptions, such as the power to execute the laws, direct the military, and make appointments. 1 id. at 244. Furthermore, unlike the Pinckney or Hamilton Plans, the New Jersey Plan did not grant the "executive authority" to the national executive. Thus, the New Jersey Plan's federal executive seemed to lack all of the foreign affairs authority that one would expect to find in an executive. This particular aspect of the New Jersey Plan did not make its way into the Constitution.

215. $1 \mathrm{id}$. at 65 . Curiously enough, Pinckney's early comments apparently contradicted his own plan, in which the Executive would have had residual foreign affairs powers. The Pinckney Plan is difficult to reconstruct. Although fragments were found among the papers of the Committee of Detail, 2 id. at 134-37, 157 n. 15, 158, 159, the discussion that follows comes from Max Farrand's reconstruction, 3 id. at 604 . Like the Virginia Plan, Pinckney's plan vested the President with the "executive authority of the U.S." 3 id. at 606 . While Congress would create offices and appoint officers in the Department of Foreign Affairs (among others), the President would be able to "inspect" the Department and call upon the Secretary in charge of the Department for advicc. $3 \mathrm{id}$. at 606,608 . Congress, however, would regulate Indian affairs and commerce with foreign countries. $3 \mathrm{id}$. at 607 . Because Pinckney's plan did not explicitly allocate many foreign affairs powers (e.g., treaty-making and communications), such matters would have been left to the "executive authority." Pinckney's comments also were in tension with his support for an executive council where the Secretary for Foreign Affairs would serve at the President's pleasure, draft treaties, and attend to foreign relations matters. $2 \mathrm{id}$. at 343-44.

Three decades after the Philadelphia Convention, Pinckney submitted a substantially different draft to John Quincy Adams when the latter sought to gather records relating to the Convention. Although Farrand doubted its accuracy (he believed the plan sent to Adams was "constructed on an entirely different framework" than what we know about Pinckney's original plan), it is worth noting that the reconstructed plan put the Senate at the center of foreign policy by ceding to it "the sole and exclusive power to declare War \& to make treaties \& to appoint Ambassadors \& other Ministers to Foreign nations." 3 id. at 599. Moreover, Congress as a whole was given the power to regulate captures and the power to codify the law of nations. $3 \mathrm{id}$. at 598 . Nevertheless, the President would still enjoy "the Executive Power of the United States" and thus would enjoy whatever foreign affairs rights were not already granted to the Senate or Congress. In addition, the plan explicitly provided that the President would "recieve public Ministers from foreign nations." 3 id. at 599.

216. 1 id. at 65 . 
proper guide in defining the Executive powers. Some of those prerogatives were of a Legislative nature. Among others that of war \& peace \&c." 217

James Madison agreed: "[E]xecutive powers ex vi termini do not include the rights of war \& peace \&c." ${ }^{218}$ But he went further than merely voicing opposition. Madison moved that the Committee of the Whole strike the Virginia Plan's list of executive powers. In its place, Madison proposed that the executive carry into effect the national laws, appoint officers not otherwise provided for in the Constitution, and "execute such other powers as may from time to time be delegated by the legislature." ${ }^{219}$ The Committee later struck a version of the last power as redundant. ${ }^{220}$ Because the new list no longer included the Confederation's "Executive rights" nor any general vesting of executive power, Madison's executive would not possess any executive powers over foreign affairs.

The criticisms of the Virginia Plan and its subsequent modification reveal that delegates understood that the conventional meaning of executive power included foreign affairs powers. To be sure, some of the delegates did not view the "Prerogatives of the English Monarch as a proper guide for defining the Executive powers." ${ }^{221}$ Indeed, James Wilson suggested that "some" foreign affairs prerogatives might be legislative in nature. ${ }^{222}$ Yet, these same delegates recognized that the commonplace understanding of executive power included foreign affairs powers. Hence, their immediate objection upon the Committee's consideration of a proposal that the national executive would have the "Executive rights" of the old Congress, and hence their support for Madison's substitute list that omitted this particular power. Wilson and others might have quibbled with the standard definition of the executive power, but they clearly recognized that theirs was the minority position. Indeed, unless one believes that these Framers understood the common definition of executive power, their reasons for opposing the vesting of the executive rights of the Confederation in the President make no sense. Thus the very need to modify the Virginia Plan

217. 1 id. at 65-66.

218. $1 \mathrm{id}$. at 70 (notes of Rufus King). Madison was correct in declaring that the literal, essential meaning of executive power (the power to execute the law) did not include power over war and peace. But by the eighteenth century, executive power had acquired a supplementary foreign affairs meaning because the essential executive power and the federative power were generally wielded by the same entity. In other words, common usage reflected that the executive power had acquired a meaning that went beyond the narrow meaning. As we discuss later, Madison adopted inconsistent positions on the relationship between executive power and foreign affairs. See infra Part VII.

219. 1 id. at 67.

220. Id.

221. $1 \mathrm{id}$. at 65 (comments of James Wilson).

222. Id. Delegate William Pierce's notes suggest that Wilson made the more extravagant claim that the "Writers on the Law of Nations" understood war and peace as legislative powers. 1 id. at 73-74. We are not aware of whom Wilson might have had in mind when he supposedly made this claim. 
confirmed that the executive power, as ordinarily understood, included power over foreign affairs. ${ }^{223}$

After this modification of the Virginia Plan, there was no sustained consideration of foreign affairs until the Committee of Detail. ${ }^{224}$ As initial draftsman for the Committee, ${ }^{225}$ Edmund Randolph specified the allocation of some foreign affairs authorities. In an early draft, the legislature was to "make war," "enact articles of war," send ambassadors, provide punishment for offenses against the law of nations, and declare the law of piracy and captures ${ }^{226}$ In addition, either the legislature as a whole or the Senate alone was to make treaties of commerce and treaties of peace or alliance ${ }^{227}$ Underscoring the situation's fluidity, a subsequent Committee of Detail draft listed the power to make treaties of commerce, peace, and alliances and the power to "send" ambassadors among the Senate's particular powers. ${ }^{228}$ At this stage, the executive lacked the residual executive power, and the only apparent foreign affairs authority lodged with it was the power to receive ambassadors. ${ }^{229}$

223. One might be tempted to argue that since war and peace were described as legislative powers by Wilson, the Virginia Plan's delegation of the legislative rights of the Confederation to the new Congress would have been sufficient to convey all foreign affairs powers to Congress. Two issues make such an argument quite problematic. First, the executive power over foreign affairs covered more than mere questions of war and peace. Although Wilson and others might have regarded these two powers as inappropriate for the executive, other powers (such as commercial treaty-making) might have been perfectly appropriate executive powers. Indeed, no one indicated that generic treaty-making was inappropriate for the executive, because the discussion apparently focused on war and peace. Second, the very act of opposing the vesting of the "executive" rights of the Confederation in the executive on the ground that war and peace might be considered executive powers was an admission that such powers were not generally considered legislative in nature. See 1 id. at 65-66 (comments of Charles Pinckncy) (admitting as much).

224. The Committee of Detail received various resolutions of the Convention and was charged with reporting out a Constitution that was consistent with those resolutions. 2 id. at 95 . Given the lack of a prior systematic discussion regarding the allocation of foreign affairs authority, these resolutions provided little guidance to the Committee members. Although the New Jersey Plan seemed to suggest that Congress would retain its executive power over foreign affairs, no one commented on this aspect of the plan. On the other extreme, no one made much of Hamilton's plan to vest the executive power over foreign affairs with the President, with the Senate declaring war and approving treaties.

The few isolated comments regarding foreign affairs lacked any sound basis in the decisions actually made by the Committee of the Whole or the Convention. Compare 1 id. at 426 (statement of James Wilson) (assuming that the Senate would be the depositary of war and treaty powers), and $2 \mathrm{id}$. at 53-54 (statement of Gouverneur Morris) (assuming that the Secretary for Foreign Affairs would exercise his functions in subordination to the Chief Executive), with 2 id. at 129-33 (consisting of various resolutions sent to the Committee of Detail, none of which spoke to the allocation of foreign affairs power).

225. THACH, supra note 202, at 111.

226. 2 THE RECORDS OF THE FEDERAL CONVENTION OF 1787, supra note 172, at 143-44.

227. Both authorities were listed among Congress's powers, but next to each Randolph had scribbled "qu: as to senate," 2 id. at 143 , thus indicating that the Senate alone might ultimately exercise them.

228. 2 id. at 155

229. 2 id. at $145-46$. 
James Wilson drafted the Committee's final report in which the President would enjoy a residual foreign affairs power. Congress had the "legislative power" along with specific foreign affairs authority: the powers to make war, regulate captures, punish piracy and offenses against the law of nations, raise armies, and build fleets. ${ }^{230}$ The Senate would make treaties and appoint ambassadors. ${ }^{231}$ However, in addition to retaining the power to receive ambassadors, the President would enjoy the "Executive Power of the United States." 232 Thus, while many significant foreign affairs powers would go to Congress or the Senate, the national executive would possess residual foreign affairs authority as a result of the reintroduction of the executive power concept. By stripping away significant foreign affairs authority, the Committee of Detail had "defanged" the executive power. Granting the President residual foreign affairs powers could no longer alarm delegates because crucial foreign relations powers were lodged elsewhere. Thus by partly putting back on the table what the Committee of the Whole had previously taken off, the Committee of Detail reintroduced the idea that the executive should manage foreign affairs, but it did so in a manner that ensured that many consequential foreign affairs powers were not vested in the executive.

The Committee of Detail's proposed allocation apparently generated little discussion. Nonetheless, the Convention's general tenor had changed, with delegates now voicing support for (or assuming) a significant presidential role in foreign affairs. For instance, Charles Pinckney and Gouverneur Morris jointly proposed an Executive Council of State where the Secretary for Foreign Affairs would serve during the President's pleasure, correspond with all foreign ministers, prepare draft treaties, and generally attend to the foreign relations of the United States. ${ }^{233}$ Other delegates deemed the treaty ${ }^{234}$ and war powers ${ }^{235}$ to be properly executive.

230. 2 id. at 182 .

231. 2 id. at 183 . This phrasing was arguably more narrow than the original Randolph draft. The power to "send" ambassadors presumably encompassed the power to appoint and to instruct them. The power to appoint might have only covered the former.

232. 2 id. at 185

233. $2 \mathrm{id}$. at 343 . In addition, the Secretary, in conjunction with others, was to advise the President with written opinions. 2 id. at 343-44. The Council of State was the genesis of the Constitution's Opinions Clause.

Given his prior comments about executive power, Pinckney cannot be viewed as a steady supporter of an executive role in foreign affairs. Supra note 215. Moreover, prior to his joint proposal, Pinckney had suggested that the Senate had the authority to manage foreign affairs, 2 THE ReCORdS OF THE FEDERAL CONVENTION OF 1787, supra note 172 , at 235 , and that the Senate should have the power to make war, $2 \mathrm{id}$. at 318. And when the Committee of Eleven granted the President the power to appoint all officers including ambassadors with the consent of the Senate, Pinckney was against the Senate's role in appointments except where ambassadors were concerned. In the case of ambassadors, Pinckney thought that the President's role was inappropriate. $2 \mathrm{id}$. at 539. Pinckney, therefore, was an inconsistent proponent of giving foreign affairs powers to the President.

234. 2 id. at 297 (comments of John Mercer). 
The well-known war power discussion also bolsters the case that the President was understood to have residual foreign affairs powers. At one point during the proceedings, the Convention sought to grant Congress the power to "make war." 236 Madison and Elbridge Gerry thought that "make" war was too broad and implied that the President would not be able to repel sudden attacks. They proposed that the Convention substitute "declare" for "make." ${ }^{237}$ Although some delegates opposed the change (one feared it narrowed congressional power too much), the amendment passed. ${ }^{238}$ Because the amendment did not formally grant the President the power to repel attacks, however, the delegates must have assumed that the President would already enjoy such authority (in the absence of a congressional power to make war). Such authority could have come from the combination of the Vesting Clause and the Commander-in-Chief Clause. By limiting Congress's war power, the delegates understood that they had correspondingly augmented the President's residual executive power.

Such sentiments and assumptions probably account for the changes wrought by the so-called Committee of Eleven. The Committee, which was to rework various propositions left unfinished by the Convention, reported out language that granted the President the power to make treaties with the advice and consent of the Senate. ${ }^{239}$ Moreover, the President would now appoint ambassadors, and the Senate would review proposed presidential appointments. ${ }^{240}$

By granting the President the principal role in treaty-making and ambassadorial appointments, the delegates signaled their view that the plural Senate should not have sole authority over these areas. At the same time, by preserving some Senate role in treaties, the delegates made it difficult for the Chief Executive to adopt significant foreign compacts that harmed the national interest. While the Committee of Detail had previously marked the Senate as executive, the Senate's executive nature became all the more obvious with its new connections to the President. On certain executive subjects, the Senate would serve as an executive council. ${ }^{241}$

Where foreign affairs was concerned, the Convention was hardly a tidy affair. But certain implications seem reasonably clear. First, there is no evidence that the delegates somehow changed the accepted definition of

235. 2 id. at 318 (comments of Pierce Butler).

236. $I d$.

237. Id.

238. 2 id. at 319.

239. 2 id. at 498.

240. 2 id. at 498-99.

241. Although there were some subsequent changes to the mechanics of foreign affairs, none altered the previous allocation and none seriously challenged the President's crucial residual role. 
executive power. ${ }^{242}$ Some delegates clearly did not want an independent executive to have certain foreign affairs authority (power over war and peace) and thus objected to the wholesale grant of the Confederation's "Executive rights" to the new executive. But no one voiced support for completely eliminating the executive's foreign affairs function. Indeed, when a significant but residual executive foreign affairs role was reintroduced by the Committee of Detail, no one sought to strike the language or even complained. Properly cabined and declawed, few could object to the executive's residual power over foreign affairs.

Second, based on this conventional meaning of executive power, the Convention's final product envisioned a partial transfer of foreign affairs authority from the Continental Congress to the new national executive. Recall that the old Congress possessed the entire executive power over foreign affairs. Whether they had sought to do so or not, the delegates had partly answered Jay's pleas for separation of executive and legislative tasks. The President's residual executive power ensured that at least some foreign affairs functions would more likely benefit from secrecy, dispatch, and responsibility. As to the residual executive powers over foreign affairs, there would no longer be a plural executive but a unitary one instead.

Third, by splintering the executive power over foreign affairs across three entities, the delegates had rejected the wisdom of Locke and Montesquieu. The executor of the laws would not enjoy the entire executive power over foreign affairs. Instead, Congress could make certain foreign affairs decisions $\mathrm{s}^{243}$ that the executive would have to execute faithfully. Moreover, the Senate would serve as an executive council regarding treatymaking and ambassadorial appointments. As to these powers, the delegates effectively elected to continue employing a plural executive generally (but not always) guided by a chief executive.

The Philadelphia Convention offers scant support for either the congressional primacy or the presidential primacy theory. ${ }^{244}$ Although a few

242. That the Constitution lists certain traditional executive powers in Article I, Section 8 in no way undermines our historical reading of executive power. Although we take no position on whether the Convention redefined certain types of executive powers (such as declaring war and regulating captures) as legislative powers, we note that other powers found in Article I were not considered legislative in nature. See THE FEDERALIST NO. 65 (Alexander Hamilton) (discussing the Senate's judicial role in impeachments). Even if the Constitution contemplated a novel foreign affairs taxonomy, with some powers labeled legislative rather than executive, it still is the case that those residual powers not granted to Congress remained executive powers. Given what was said during the ratification debates and in the Washington Administration, no one can claim that the Constitution somehow completely effaced the prior definition of executive power. See infra Parts VI-VII.

243. Subject, of course, to a presidential veto.

244. Those who contend that the foreign affairs Constitution is simply incomplete may have some cause for cheer. These scholars could point out that most foreign affairs issues were not even discussed at Philadelphia. If these powers were not considered, the delegates may not have allocated them. Hence posterity must apportion these powers. Unfortunately, this reading does not 
delegates referred to some foreign affairs powers as legislative in nature, no one declared that the executive ought to have no role in foreign affairs. Nor did anyone declare that the President would be limited to treaty-making, appointing ambassadors, and receiving ambassadors. To the contrary, the work of the Committee of Detail and the Committee of Eleven ensured that the Chief Executive would enjoy foreign affairs authority beyond those powers specifically enumerated. Moreover, no one spoke in favor of Congress enjoying all the executive powers over foreign affairs, as it had under the Articles. On the other hand, advocates of presidential primacy have little to hang their hats on either. If one ignores the President's executive power (as presidential primacists typically do), then one must confront the reality that the President's most significant specific foreign affairs role (treaty-making) was added at the end of the Convention. Prior to that last-minute addition, the only other specific power (receiving ambassadors) was added by the Committee of Detail, but with no discussion of its scope or extent. This drafting history, with little explicit commentary on foreign affairs, should hardly encourage those who insist that, notwithstanding the lack of textual support, the President must dominate foreign affairs.

\section{THE EXECUTIVE POWER OVER FOREIGN AFFAIRS IN THE RATIFICATION DEBATES}

Although the Convention's treatment of foreign affairs was somewhat disjointed, those participating in the ratification struggle generally had little difficulty discerning the resulting allocation. With the scene shifting from Philadelphia to the thirteen states, pamphleteers and conventioneers usually understood the transformed foreign affairs landscape. Two lessons emerge from their praises, protests, and portraits of the Constitution. First, by virtue of the executive power, the President would have those residual foreign affairs powers not otherwise allocated and would serve as the steward of the country's international undertakings. Except where explicit authority was vested elsewhere (such as Congress's war power) or shared (such as the Senate's role in treaty-making), the President would unilaterally wield the executive power over foreign affairs for the United States. Second, although Congress enjoyed particular foreign affairs powers, no one suggested that Congress would enjoy all foreign affairs powers by virtue of the obviously

account for the accepted eighteenth-century meaning of executive power. Moreover, this reading of Philadelphia's handiwork cannot make sense of how others subsequently read the Constitution. No one during the ratification and post-ratification stages asserted that the Constitution was woefully incomplete. Instead, people understood that the executive had the residual foreign affairs authority. Many of these same people cited the President's executive power as the authority for the proposition. See infra Parts VI-VII. 
limited enumeration of its powers. Thus no one insisted that Congress would control foreign relations generally or even specific, seemingly unapportioned powers like communications or direction of diplomatic personnel. Because Congress only had discrete foreign affairs powers, the problems of a plural executive (unwieldiness, slowness, and indiscreetness) would be greatly mitigated. Outside the limited but significant exceptions to the executive power, the nation would enjoy the vaunted advantages of a unitary executive-vigor, dispatch, and secrecy.

Sometimes the President's crucial residual role was discussed openly. Addressing the North Carolina ratifying convention, James Iredell observed that the President was to "regulate all intercourse with foreign powers." 245 Even where the Senate had an executive role, the President was still the "primary agent" and the Senate was but a council designed to preclude improper decisions. ${ }^{246}$ Likewise, Hamilton repeatedly confirmed the President's foreign affairs role. In The Federalist No. 72, he affirmed that the "actual conduct of foreign negotiations" is executive in nature and that persons who undertake this task should be superintended by the Chief Executive. ${ }^{247}$ Likewise, The Federalist No. 84 observed that the "management of foreign negotiations will naturally devolve" upon the President subject to the Senate's general desires and ultimate concurrence. ${ }^{248}$ Other times, the President's role was left to implication. For example, after observing that the President's powers belonged to the executive branch and could not be properly vested elsewhere, "A Native of Virginia" noted that the Senate's role in treaty ratification meant that the Constitution had "lessened" the President's authority. ${ }^{249}$ Clearly, the writer regarded the Senate's treaty role as a derogation of executive authority, because he envisioned a baseline of executive control of foreign affairs. Likewise, when James Iredell spoke of the President sending a spy overseas, ${ }^{250}$ he assumed that the executive's power over foreign affairs would authorize the executive's control of such agents.

Noticeably absent from most foreign relations discussions, the House of Representatives was the odd institution out. To our knowledge, no one made the incredible claim that the House shared (with the Senate) the residual foreign affairs powers or went further by claiming that Congress somehow was in charge of foreign affairs generally. In fact, some went too far to the opposite extreme, arguing that the House was unfit for foreign

245. 4 ELLIOT'S DEBATES, supra note 173, at 127.

246. 4 id. at $127-28$.

247. THE FEDERALIST NO. 72, supra note 113. at 412 (Alexander Hamilton).

248. THE FEDERALIST No. 84, supra note 113 , at 519 (Alexander Hamilton).

249. OBSERVATIONS UPON THE PROPOSED PLAN OF FEDERAL GOVERNMENT (1788), reprinted in 9 THE DOCUMENTARY HISTORY OF THE RATIFICATION OF THE CONSTITUTION, supra note 201 , at 655,681 .

250. 4 ELLIOT'S DEBATES, supra note 173 , at 113. 
relations (thereby hinting that it had no foreign affairs role). Its members were said to lack the stability and comprehensive knowledge of foreign politics to play a role in foreign affairs. ${ }^{251}$ More discerning figures understood that although the House would play a distant third fiddle to the President and Senate, it had a role nonetheless. ${ }^{252}$

While the President would enjoy residual foreign affairs authority and the House was the weakest foreign affairs institution of the political branches, the Senate fell somewhere in the middle. The Senate would share the foreign affairs powers vested in Congress and had a share of the treaty and appointment powers. Sometimes, however, commentators went too far. A few mistakenly asserted that the Senate was somehow the President's executive partner in all foreign affairs matters. ${ }^{253}$ One Framer (who should have known better) seemed to cut out the President altogether. ${ }^{254}$ Not surprisingly, such improbable claims were never linked to constitutional text. Nor could they be, because there was no sound textual basis for treating the Senate as the President's equal across all foreign affairs matters. Nor was there any solid textual foundation for the even more fantastic claim that the Senate unilaterally would steer foreign relations. Still, these claims

251. THE FEDERALIST No. 75, supra note 113, at 426 (Alexander Hamilton); see also 2 ELLIOT'S DEBATES, supra note 173, at 302 (statement of Alexander Hamilton at the New York convention) (claiming that popular assemblies were incompetent to oversee foreign affairs); THE FEDERALIST NO. 64, supra note 113, at 377-78 (John Jay) (asserting that popular assemblies were too unstable to advise and consent on treaties).

252. E.g., THE FEDERALIST NO. 53, supra note 113, at 329-30 (James Madison) (observing that although House members would require some knowledge of treaties, the commercial laws of other countries, and the law of nations, they would not be intimately connected with "foreign negotiations and arrangements"). Given the Constitution's allocation of foreign affairs powers among the President, Senate, and House, it is easy to see why the House was perceived as the weakest in foreign affairs. It only had a role over those specific powers mentioned in Article I, Section 8. In contrast, the Senate had a role over those powers plus authority regarding treaties and foreign relations appointments. Finally, the President had sole control over the significant foreign affairs residuum and shared authority over all other foreign affairs powers (e.g., treaties, foreign commerce, and captures).

253. See 2 ELLIOT'S DEBATES, supra note 173, at 306 (statement of Alexander Hamilton at the New York convention) (declaring that the President and the Senate would manage the nation's foreign concerns); 4 id. at 265, 281 (statement of Charles Pinckney at the South Carolina convention) (making the same point); Letter XI (Jan. 10,1788), in AN ADDITIONAL NUMBER OF LETTERS FROM THE FEDERAL FARMER TO THE REPUBLICAN, reprinted in 17 THE DOCUMENTARY HISTORY OF THE RATIFICATION OF THE CONSTITUTION, supra note 201, at 265, 301,303 [hereinafter FEDERAL FARMER] (observing that the Senate was well-constituted to wield a negative on presidential treaty-making and the presidential management of foreign affairs). Just two letters later, however, the Federal Farmer criticized the Senate's agency in foreign affairs, arguing that the Senate was an improper means of "fettering, embarrassing, or controuling" the President. Letter XIII (Jan. 14, 1788), in FEDERAL FARMER, supra, at 318, 322.

254. Robert Livingston insisted that the Senate was to "transact all foreign business." 2 ELLIOT's DEBATES, supra note 173, at 323. Although Livingston would have been an unimpeachable source regarding the difficulties of leaving the executive power to an assembly (he was the Confederation's first Secretary for Foreign Affairs), he proved to be a rather poor reader of constitutional text. 
did have an extremely faint textual basis given the Senate's conspicuous roles in treaty-making and ambassadorial appointment. ${ }^{255}$

In a roundabout way, the Senate's executive treaty-making role confirms the conventional view that the President enjoyed a residual executive power over foreign affairs. Many Framers confirmed that treatymaking was executive in nature. By implication, if treaty-making was executive, the conduct of foreign affairs was undoubtedly so as well. After all, to regard treaty-making as executive was to adhere to the division laid out in Locke, Montesquieu, and Blackstone, and that taxonomy made clear that foreign affairs was part of the executive power. And if the Senate's role was an exception or a derogation from the executive power, the President would enjoy those executive powers not allocated away from the executive branch.

First, it bears noting that numerous speakers and pamphleteers regarded the Senate as executive in nature, and many deemed it an executive council to the supreme executive magistrate. Anti-Federalists charged that the Senate's executive nature violated basic separation of powers principles. The aristocratic Senate would join with the monarchical President and overwhelm the popular House. Or the Senate would be unable or unwilling to try executive officers for impeachable offenses given its intimate connection with the President. Federalists did not deny that the Senate had executive features. They either lamented the fact or argued that the separation of powers did not preclude the Senate's participation in executive matters.

Even more significant for our argument is why the Senate was regarded as having a distinctively executive tinge. Although its appointment check led some to regard the Senate as executive in nature, its treaty role was just as significant in leading many to deem it a second executive branch. Some

255. Of course, there is a separate issue of the extent to which the Senate would be involved in treaty negotiation. Could the Senate instruct the President as to the acceptable terms? Could senators be called upon to negotiate with foreign powers? Some envisioned that the Senate would be heavily involved with foreign negotiations. 2 THE DEBATE ON THE CONSTITUTION 6I (Bemard Bailyn cd., 1993) (observing that the Scnate was the proper place for management of treaty negotiation given its greater ability to keep secrets); 2 ELLIOT'S DEBATES, supra note 173, at 9192 (statement of Theophilus Parsons) (claiming that in its executive capacity, the Senate conducts foreign negotiations); 2 id. at 291 (statement of Chancellor Robert Livingston) (arguing that because the Senate was to form treaties and negotiate with foreign powers, senators should have long terms to gain familiarity with foreign countries and their diplomatic agents); THE FEDERALIST NO. 62, supra note 113, at 364 (James Madison) (observing that senators would participate “immediately in transactions with foreign nations"); THE FEDERALIST NO. 64 (John Jay) (observing that the President would conduct actual negotiations but may seek preliminary senatorial approval for his tactics and goals); THE FEDERALIST No. 66 (Alexander Hamilton) (observing that the Senate might impeach the President for failure to adhere to treaty negotiation instructions). We do not take any position on the Senate's precise role in treaty-making, except to note that the Senate's unique foreign affairs role is limited to treaty-making and appointments. As noted above, there is no textual basis for any claim that the Senate enjoys executive power over foreign affairs generally. 
praised the Senate's role and thereby confirmed that treaty-making was executive. For instance, at the Virginia ratifying convention, Francis Corbin praised the Constitution for vesting the authority in a manner different "from every government we know," since the Constitution "steers with admirable dexterity between the two extremes, neither leaving it to the executive, as in most governments, nor to the legislature, which would too much retard ... negotiation[s]." 256

Others hurled complaints at the Senate's executive role in treatymaking. One faction protested that the Senate's executive role would make the President its pawn and lead to tyranny. For instance, John Smilie, a ratification opponent at the Pennsylvania ratifying convention, complained that because senators had "an alarming share of the executive," given their treaty-making role, ${ }^{257}$ they would make the President their tool. ${ }^{258}$ Another group groused that the treaty power coupled with the Supremacy Clause ensured that the President and Senate enjoyed the legislative and executive powers. For example, at the same convention, the "Dissent of the Minority" complained that the Senate had "various and great executive powers, viz: in concurrence with the President general, they form treaties with foreign nations." ${ }^{259}$ Such a connection, in the Dissent's view, violated the fundamental maxim of keeping fundamental powers separate. ${ }^{260}$

Likewise, in a widely reprinted letter to Governor Edmund Randolph, Richard Henry Lee complained that the Senate and the President had the "whole legislative and executive powers" because their treaties would be

256. 3 ELLIOT'S DEBATES, supra note 173, at 510 (emphasis added)

257. 2 THE DOCUMENTARY HISTORY OF THE RATIFICATION OF THE CONSTITUTION, supra note 201, at 466; see also 4 ELLIOT'S DEBATES, supra note 173, at 116-17 (statement of Samuel Spencer) (complaining about the Senate's important executive role in treaties); 4 id. at 125 (statement of Samuel Spencer) (grousing that the Senate must try impeachments of the executive even though it has extensive executive powers).

258. 2 THE DOCUMENTARY History OF THE RATIFICATION OF THE CONSTITUTION, supra note 201, at 508 .

259. The Dissent of the Minority, PA. PACKET, Dec. 18, 1787, reprinted in 2 THE DOCUMENTARY HISTORY OF THE RATIFICATION OF THE CONSTITUTION, supra note 201, at 634 .

260. Id. at 635; see also 2 THE DOCUMENTARY HISTORY OF THE RATIFICATION OF THE CONSTITUTION, supra note 201, at 459 (statement of William Findley) (objecting to the President and the Senate's legislative power over treaties).

Although James Wilson suggested at one point that the treaty power was not executive in nature, see $2 \mathrm{id}$. at 491 (observing that a single body would be truly despotic if, in addition to the treaty power, it enjoyed "executive powers"), he later seemed to have accepted the opposition's taxonomy. While describing the opposition's argument against the "blending of the legislative and executive powers in the Senate," Wilson argued that one also should examine the favorable side of a question rather than merely focusing on the negative aspects. 2 id. at 562 . Later, Wilson also claimed that with respect to the executive powers of government, the Senate could do nothing without the President, thereby admitting that the treaty power was an executive power. $2 \mathrm{id}$. at 566. The Senate only had two powers conceivably executive: appointments and treaty approval. To speak of "executive powers," then, was to speak of both of these authorities as executive in nature. 
the law of the land. ${ }^{261}$ Similar complaints were voiced in North Carolina ${ }^{262}$ and South Carolina ${ }^{263}$ Anti-Federalists clearly found the Senate's executive role an inviting target. ${ }^{264}$

The Federalist No. 75 was Alexander Hamilton's ultimately unpersuasive attempt to respond to two complaints: that the Senate would improperly wield the executive power by sharing the treaty power and that the President would inappropriately exercise the legislative power because his treaties would be the supreme law of the land. Hamilton cleverly claimed that treaties formed a "distinct department" belonging neither to the executive nor to the legislative departments. ${ }^{265} \mathrm{He}$ also opined that it would not be wise for a nation "to commit interests of so delicate and momentous a kind, as those which concern its intercourse with the rest of the world," to the President alone. ${ }^{266}$

Given the writings of Locke, Montesquieu, and Blackstone (and the numerous complaints voiced during the ratification debates), we have little doubt that treaty-making had historically been understood as part of the executive power. Indeed, although Hamilton claimed that treaty-making partook "more of the legislative than of the executive character," ${ }^{267}$ he was forced to admit that "several writers on the subject of government place that power in the class of executive authorities." ${ }^{268}$ Although this taxonomy was supposedly "arbitrary," one could similarly argue that all definitions are arbitrary. What matters is usage, and the usage was that treaty-making

261. Letter from Richard Henry Lee to Edmund Randolph (Oct. 16, 1787), in 8 THE DOCUMENTARY HISTORY OF THE RATIFICATION OF THE CONSTITUTION, supra note 201, at 61, 61 .

262. See 4 ElLiot's DEBATES, supra note 173, at 27, 28, 115 (comments of William Lenoir and William Porter).

263. See 4 id. at $265-66$.

264. In truth the complaints were positively odd because many executive powers were shared with Congress, yet there was not a similar apprehension where these executive powers were concemed. Perhaps there was a greater acceptance of certain executive powers (foreign commerce, captures, and war declaration) resting largely with the legislature rather than with a unitary executive. Treaties, on the other hand, might have been viewed as requiring secrecy and dispatch, two traits not normally associated with a multimember body.

265. The Federalist No. 75, supra note 113, at 425 (Alexander Hamilton).

266. Id.

267. Id.

268. Id. at 424. Earlier, Hamilton contradicted his claim in The Federalist No. 75. While comparing the President to the state executives, Hamilton admitted that the President's treatymaking authority made him different from the state executives because Hamilton believed that the state executives lacked such authority by virtue of the exclusive power given to the Confederation. Were the Confederation to be dissolved and the Constitution rejected, however, "it would become a question whether the executives of the several States were not solely invested with that delicate and important prerogative." THE FEDERALIST No. 69, supra note 113, at 400 (Alexander Hamilton). Given that state executives generally did not have specific treaty-making powers, see supra note 209 , the only reason anyone would speculate that the state executives would enjoy a treaty power in the absence of a national treaty-making power is that the state executives' "executive power" ceded such authority. 
was executive in nature because the control of foreign affairs was an executive power. ${ }^{269}$

Although they also had largely unsatisfactory responses to the charge that the Constitution united the legislative and executive powers, other advocates of the Constitution at least had the sense to affirm the conventional view that treaty-making was executive in character. Answering Richard Henry Lee's open letter, ${ }^{270}$ "Cassius" labeled Lee a "deliberate deceiver," because treaty-making had always been considered as "part of the executive"; indeed, Cassius viewed the Senate's check on treaty-making as a happy innovation. ${ }^{271}$ After all, treaty-making had been "safely exercised in other countries, by the executive authority alone." "272 The South Carolina Attorney General, John Julius Pringle, argued that although executives might make treaties that had the force of law, that did not mean that they had legislative power. "The making of treaties is justly a part of their prerogative: it properly belongs to the executive part of government" because only that branch could act with secrecy and dispatch. ${ }^{273}$ In North Carolina, William Maclaine observed that when the President made treaties, he did not act as a legislator "but rather in his

269. We regard Hamilton's arguments in The Federalist No. 75 as an early example of "spinning." Hamilton understood that many opponents were scoring points by declaiming the Senate's executive role and by charging that the President could make supreme laws. Rather than merely defending the Senate's executive role, Hamilton sought to confuse the issue by denying what any reader of Locke, Montesquieu, and Blackstone knew to be true. Obscuring the issue made it more difficult for opponents to complain that the Constitution blended powers in contravention of Montesquieu's maxim. After all, if treaty-making was neither a legislative nor an executive power, no one could charge that treaty-making improperly blended powers

We take no position on whether the Constitution requires that treaties be implemented through legislation or whether the Supremacy Clause obviates the need for implementing legislation. But we do deny that the Supremacy Clause somehow wholly stripped the executive power of treaty-making of its executive nature. As various commentators declared, treaty-making was understood to be executive in all nations. In America, it may have had an additional legislative tinge by virtue of the Supremacy Clause. Yet this tinge simply could not mask or overwhelm the practice of regarding treaty-making as executive in nature. Simply put, foreign affairs was an executive power; treaty-making was a branch of foreign affairs; and the Supremacy Clause did not fundamentally alter that taxonomy.

270. See supra note 261 and accompanying text.

271. Cassius I, VA. INDEP. Chron., Apr. 2, 1788, reprinted in 9 THE DOCUMENTARY HISTORY OF THE RATIFICATION OF THE CONSTITUTION, supra note 201 , at 641,645 . Later on, Brutus defended Lee against Cassius by observing that Senate participation in treaty-making would make it difficult to impeach executive officers responsible for the treaty's terms. Brutus also claimed that Lee's objection really went to the President and Senate's ability to make law without the participation of the House. Brutus, VA. INDEP. CHRON., May 14, 1788, reprinted in 9 THE DOCUMENTARY HISTORY OF THE RATIFICATION OF THE CONSTITUTION, supra note 201, at 798, 800-01.

272. Cassius I, supra note 271 , at 641,644 .

273. 4 Elliot's DeBatES, supra note 173, at 269. Given the implication of the South Carolina Constitutions of 1776 and 1778 that executives typically enjoyed the power to make treaties, supra note 209, Pringle's comments should hardly surprise. See S.C. CONST. of 1776, art. XXVI (" [T]he president and commander-in-chief shall have no power to make war or peace, or enter into any final treaty, without the consent of the general assembly and legislative council."); see also S.C. CONST. of 1778, art. XXXIII (analogous provision in the 1778 constitution). 
executive capacity." 274 William Davie likewise remarked that "in all countries and governments" the treaty-making power was "placed in the executive departments." Such allocation was necessary given the "secrecy, design, and despatch" necessary for foreign negotiations. In fact, given the requisites of treaty-making and the propriety of vesting this power with the executive, "the whole power of making treaties ought to be left to the President." ${ }^{275}$ Unfortunately, small-state jealousy had led the Convention to grant the Senate an executive role. ${ }^{276}$ Each of these responses to complaints about the mixture of the legislative and executive powers admitted that treaty-making was traditionally part of the executive power. And, of course, this conventional categorization of the treaty power confirms our claim that the executive power was understood by the ratifiers as having a foreign affairs component.

As compared to the Philadelphia Convention, the ratification fight provides even less support for the congressional primacy view. No one argued that Congress would exercise the seemingly unallocated foreign affairs authority, let alone that Congress would dominate foreign affairs. Instead, the President (with the occasional assistance of the Senate) was usually identified as the prime mover. Advocates of a nontextual presidential primacy face a similar problem. Given that the President only had three specific foreign affairs authorities, why did so many assume that the President would play the principal role? At this stage, arguments based on prudence or practice were unavailable. We think the answer can be found in the one place that presidential primacists have refused to look: the Executive Power Clause. ${ }^{277}$ Finally, those who regard the foreign affairs

274. 4 ELLIOT'S DEBATES, supra note 173, at 27-28.

275. $4 \mathrm{id}$. at 119-20. Recall that James Iredell had confirmed that treaties were executive in nature when he observed that "in the branches of executive government, where [the Senate's] concurrence is required, the President is the primary agent." 4 id. at 127-28.

276. 4 id. at 120 .

277. The debates also reveal that allocations of the executive power to Congress were allocations away from the President. For instance, numerous figures indicated that the President could not declare war. E.g., 4 id. at 287 (statement of Charles Pinckney) (noting that the President could not declare war); $2 \mathrm{id}$. at 536 (statement of Thomas M'Kean) (confirming that the consent of the people's representatives was necessary for declaring war); 4 id. at 107 (statement of James Iredell). Thomas Jefferson even more clearly noted that the congressional war power was an exception to the executive power. In a letter to James Madison, Jefferson noted that the Constitution had "transfer[ed] the power" of letting loose the dog of war "from the executive to the Legislative body." Letter from Thomas Jefferson to James Madison (Sept. 6, 1789), in 6 THE WORKS OF THOMAS JEFFERSON, supra note 200 , at 3,11 . Strictly speaking, Congress retained its executive power to declare war. Yet Jefferson was alluding to the fact that the President was to be the executive in the new Constitution, and hence the Constitution had, from that perspective, transferred part of the executive's customary authority to Congress.

It is worth noting that no one bothered to mention that the judiciary could not declare war precisely because no one would have thought that the judiciary would ever have such authority. In other words, people noted that the President could not declare war precisely because they viewed Congress's authority as a favorable innovation and departure from the conventional allocation of executive power. 
Constitution as radically incomplete have some explaining to do. Not one of the Constitution's many opponents charged that it utterly failed to allocate significant foreign affairs authority. The incentive to make such an indictment was undoubtedly there; indeed, far less credible attacks were launched. No one voiced the charge because it simply could not stick. If one carefully examined the Constitution, one knew that the President had the executive power over foreign affairs except in those critical areas where the Constitution required that he share it with the Senate or required the passage of a statute.

\section{THE EXECUTIVE POWER OVER ForeIGN AFFaIRS IN WASHINGTON'S ADMINISTRATION}

We have amassed considerable evidence that in the eighteenth century, the executive power included authority over foreign affairs; that during the Articles era, Congress was understood to enjoy the executive power over foreign affairs; that the Department of Foreign Affairs was regarded as an executive department; and that the Framers and ratifiers recognized that the President would enjoy foreign affairs authorities beyond those specifically enumerated in Article II, Sections 2 and 3. On the other hand, we have explained that under the Constitution, Congress lacks a textual hook upon which it might lay claim to those residual powers over foreign affairs not otherwise granted to the President. Admittedly, Congress enjoys unquestioned foreign affairs authority over discrete foreign affairs matters (war, foreign commerce, marque and reprisal, and the law of nations). But these discrete powers are a far cry from the type of authority that might be thought to invest Congress with a sweeping residual power over foreign affairs. Indeed, during the drafting and ratification phases, no one suggested that Congress would enjoy anything close to plenary authority over foreign affairs as it had under the Articles. Nor did anyone suggest that Congress would enjoy all the foreign affairs authorities not allocated to the President. We believe these materials and arguments are sufficient to establish that the President's executive power grants the power to control foreign affairs except where the Constitution specifically allocates authority to Congress or requires that it be shared with the Senate.

In this Part, we test our textual theory (and its nontextual alternatives) against the actual practices of the Founding generation. The inquiry also transforms our relatively abstract claims into a more practical inquiry by enabling us to focus on the details of foreign affairs. Because we make a claim about the original understanding, and for reasons of tractability, we focus on Washington's administration. His tenure immediately followed the 
Constitution's ratification, and we believe that the practices of that early era are more apt to adhere to the Constitution's original understanding. ${ }^{278}$ Unlike practices begun decades or centuries later, the conventions of that unprecedented era are less likely to be corrupted by the passage of time and institutional bias. $^{279}$

As the reader will learn, the legislative statutes and proceedings and the executive practices highlighted below confirm the textual, structural, and historical claims made earlier. Washington, as America's chief diplomat, understood that he possessed broad powers over foreign affairs. He instructed the Secretary of State, ambassadors, and consuls. He was the sole organ of communication with other countries and their emissaries. He established the foreign policy of the United States. He did all this, notwithstanding the absence of precisely enumerated constitutional powers over these areas, because he had the executive power over foreign affairs.

All the while, Washington generally took care to respect constitutional limits. In particular, despite aggressively asserting his residual foreign affairs authority, he respected Congress's significant foreign affairs prerogatives. He never declared war, regulated foreign commerce, or appropriated funds. Although Washington had the sole control of much of foreign affairs through the residual executive power, he understood that Congress also had substantial constitutional foreign affairs powers.

In the pages that follow, we discuss a number of key events from the Washington Administration. Rather than providing a chronological account of how the administration addressed foreign affairs questions, ${ }^{280}$ we attempt to divide the era into discrete foreign affairs issues. In Section VII.A we discuss the creation, funding, and control of the Department of Stateactions that bespoke a residual presidential foreign affairs power. What had been Congress's department under the Articles became the President's

278. Ending our inquiry with the Washington Administration may seern a tad arbitrary. One could look beyond the General's tenure. Nevertheless, space considerations require some lines to be drawn, and we think practices in the Washington Administration, being the most proximate to the Founding, are most probative of the common understanding of the Framers.

279. We are acutely aware that not all post-ratification practices will cohere with the original meaning of constitutional text. Indeed, one of us has taken great pains to make this very point. See Calabresi \& Prakash, supra note 2, at 554, 558-59. Nevertheless, where post-ratification practices harmonize with a sensible reading of constitutional text and the pre-ratification discussions, we think that the understandings underlying these practices are likely the ones codified by the Founding generation. Where foreign affairs is concerned, the first federal politicians were not led off the original meaning path.

280. On the Washington Administration generally, see STANLEY ELKINS \& ERIC MCKitRick, THE AGE OF FEDERAlism (1993); JAMES THOMAS FleXNer, GeORGE WASHINGTON AND THE NEW NATION, 1783-1793 (1970); FORREST MCDONALd, ThE Presidency of George Washington (1974); and Glenn A. Phelps, George Washington AND AMERICAN CONSTITUTIONALISM (1993). The leading foreign affairs events are recounted in Agraham SOFAER, War, Foreign AfFairs AND CONSTITUTIONAL POWER (1984); the leading legislative events are recounted in DAVID CURRIE, THE CONSTITUTION IN CONGRESS: THE FEDERALIST PERIOD 1789-1801 (1997). 
department under the Constitution. Section VII.B turns to the control of foreign officials resident in the United States, such as ambassadors and consuls. Once again, Washington exercised authority that went beyond his Article Il, Sections 2 and 3 powers. In Section VII.C we highlight Washington's monopoly of foreign discourse. In episode after episode, foreign countries understood that all communications were to be funneled through Washington. Moreover, Congress seemed to understand that it had to remain mute and deaf where international discourse was concerned. Finally, Washington himself understood that he was the only proper receptacle of foreign communications and was the only one who could speak on behalf of the United States.

We next take up the events surrounding the Neutrality Crisis of 17931794, in which it appeared that the United States might be drawn into the war between England and France. We first discuss in Section VII.D the power of treaty termination, a matter considered carefully by the administration because treaties between the United States and France, if not terminated, threatened to bring the United States into the war. In Section VII.E we then turn to the issuance of the Neutrality Proclamation, one of Washington's best-known foreign affairs actions, and one that revealed the executive's power to establish nonbinding foreign policy. In the Proclamation, and in subsequent elaborations of it, Washington declared that the foreign policy of the United States was to maintain a strict neutrality. He took this momentous step without consulting Congress. In so doing, Washington confirmed that as part of the executive power over foreign affairs, the President unilaterally could announce the foreign policy of the United States. Indeed, Washington repeatedly announced the foreign policy of the United States, with the Neutrality Proclamation standing out as the most notorious instance.

Yet, as Section VII.F explains, there were generally acknowledged limitations on the power to announce a policy. Although Washington could announce foreign policies, he could not attach domestic sanctions to their violation. Washington never claimed that his Neutrality Proclamation had legal force of its own right, and he was not successful in finding another legal basis for enforcing what he had said to be U.S. policy. Congressional action was necessary to back up Washington's policy with law. And hence, Congress would have to serve as indispensable assistant in ensuring that U.S. foreign policy had domestic legal effect.

We end with a brief examination of Congress's foreign affairs powers in Section VII.G. Here, we show first that Washington was cautious and deferential when acting in areas assigned to Congress by the Constitution, such as declaring war and regulating foreign commerce. This contrasts sharply with Washington's bold assertion of executive power over foreign affairs in areas not assigned to Congress-confirming that he, like we, 
viewed his executive power as residual. We also illustrate Congress's derivative powers over foreign affairs: Even in areas not otherwise included within Congress's enumerated powers, Congress passed legislation supporting presidential policies, as part of its ability to carry into execution powers granted to other branches.

As should be obvious, our aim is not to provide the definitive treatment of foreign affairs during the Washington Administration but is instead to provide a flavor of how the first federal politicians dealt with questions regarding the allocation of foreign affairs powers. As we shall see, these politicians consistently acknowledged the President's residual executive power over foreign affairs.

\section{A. The President's Control of the Instruments of Foreign Affairs}

The Department of State and its diplomats are, by common understanding, instruments of the President; but absent some explanation of how the Constitution conveys foreign affairs power to the President, it is not obvious why this should be so. Unlike other executive officers, the Secretary of State is not primarily concerned with law execution nor with other matters (such as the military) contained in Article II, Sections 2 and 3. As we show in this Section, Washington, his advisers, and his contemporaries in Congress and elsewhere immediately assumed, upon the commencement of the new government, that the President controlled the Department. Moreover, this assumption rested on the understanding that management of foreign affairs was an executive function constitutionally conveyed to the President as part of the executive power.

\section{Washington Dominates the Old Department of Foreign Affairs}

Recall that under the Articles, Congress had chartered an executive Department of Foreign Affairs under its superintendence. Notwithstanding the Constitution's ratification, Congress did not immediately reform and reconstitute the executive departments to reflect the novel landscape. Rather, the ancien régime's executive institutions continued operating. In particular, Secretary for Foreign Affairs John Jay continued in office well into the first year of Washington's term. Of course, there was one rather significant change relating to the executive departments: Whatever their organic statutes provided, the Constitution had superimposed a vigorous and independent Chief Executive over these executive departments. With Washington at the helm of the ship of state, there was no doubt as to who would direct these departments. Nowhere was this truer than with the department responsible for foreign affairs. 
There can be no doubt that Jay was Washington's subordinate, for they both comported themselves as if Jay was the instrument of the Chief Executive. From the beginning, Washington directed Jay. ${ }^{281}$ In sending a consular treaty to the Senate, Washington observed that Jay had his "orders" to communicate to the Senate whatever papers and information it thought requisite. ${ }^{282}$ In another instance, Washington directed Jay to send an emissary to Canada to fix a meridian line. ${ }^{283}$ Likewise, Jay, in a letter to an American agent resident in Morocco, noted the prominent role that the new President would play in foreign affairs. There had been a peaceful revolution and the new President now enjoyed the "great executive powers" that were formerly held by Congress. Accordingly, missives that the agent had addressed to the President of Congress were delivered to the new President who, according to Jay, possessed power and prerogatives similar to the English Crown. "In obedience to the orders of the President," Jay informed the agent that the President was "well pleased" with the agent's conduct. ${ }^{284}$ In administering a constitutional lesson to the envoy, Jay left behind one for posterity. To a significant degree, the Constitution had stripped from Congress the executive power over external affairs and had vested it in the President.

281. After assuming office, one of Washington's first executive acts was to instruct John Jay. Adverting to the unsettled state of the "Executive Departments," Washington observed that it would be useful to have the "real situation of the several great Departments, at the period of my acceding to the administration of the general Government." Letter from Genrge Washington to the Acting Secretary for Foreign Affairs (June 8, 1789), in 30 THE WRITINGS OF GEORGE WASHINGTON 343, 343-44 (John C. Fitzpatrick ed., 1939). To that end, he ordered Jay to draft a "clear account of the Department" as may be sufficient to convey a "full, precise, and distinct general idea of the" nation's foreign affairs. $30 \mathrm{id}$. at 344 . He also told Jay that he had time to inspect documents relating to such forcign affairs matters as were likely to arise in the new administration. Id. Washington sent similar letters to the executive holdovers in the Trcasury and War Departments. See $30 \mathrm{id}$. at $344 \mathrm{n} .30$. Washington's letter to Jay revealed his consistent belief that he had residual executive prerogatives over foreign affairs and that Jay (and his Department) were executive in nature. When Washington sought an opinion from Jay, he was requiring his first written opinion pursuant to his power under the Constitution. See U.S. CONST. art. II, \& 2, cl. 1 ("[The President] may require the Opinion, in writing, of the principal Officer in each of the executive Departments, upon any Subject relating to the Duties of their respective Offices ...."). But he did not merely seek opinions; he also sought the documents he would need to review in order to make decisions. The Opinions Clause was hardly sufficient authority to authorize his document demands. Instead, his executive power over foreign affairs made the department subject to the Opinions Clause and also enabled him to order the records and documents so that he could prepare himself to make foreign affairs decisions.

282. Letter from George Washington to the Senate (June 11, 1789), in 30 THE WRITINGS OF GEORGE WASHINGTON, supra note 281 , at 346, 346-47.

283. Letter from George Washington to the Secretary of War (Sept. 5, 1789), in 30 THE WRITINGS OF GEORGE WASHINGTON, supra note 281, at 394, 394 (informing the Secretary of War that Washington had "direct[ed]" Jay to send a messenger to Canada to help ascertain a certain point in Canada that would be useful in executing a statute directing a survey of U.S. lands).

284. Letter from John Jay to Giuseppe Chiappe (Dec. 1, 1789), in GEORGE WASHINGTON PAPERS, http://memory.loc.gov/mss/mgw/mgw2/028/1120092.jpg, http://memory.loc.gov/mss/ mgw/mgw2/028/1 150095.jpg. 
For advocates of legislative supremacy, Jay's conduct must appear inexplicable. Although the statute that created his office required that he obey Congress in carrying out his duties, after ratification he immediately came under the President's direction. Moreover, legislative primacists must regard Washington's direction of Jay as rank usurpation. By what authority could Washington direct Congress's Secretary? One can regard Washington's direction of Jay and Jay's post-ratification tenure as ordinary only if one admits that the Constitution created a new executive principal, the President. The Chief Executive would direct this executive department and Secretary.

Of course the conduct and correspondence of Washington and Jay in the early days of the new republic were hardly singular. Throughout his term, Washington controlled the instruments of foreign affairs and acted on his belief that he enjoyed a residual executive power over foreign affairs.

\section{Congress Creates a New Executive Department of Foreign Affairs}

We next consider the legislative handiwork of Washington's institutional rival, Congress. By citing its complete foreign affairs authority under the Articles and by pointing to its considerable foreign affairs powers under the new Constitution, Congress might have had some basis for laying claim to the foreign affairs mantle. Nevertheless, although one might have expected aggrandizement, Congress repeatedly acted as though the President enjoyed broad residual control over foreign affairs. In its Act for Establishing an Executive Department, To Be Denominated the Department of Foreign Affairs, ${ }^{285}$ Congress signaled this unremarkable understanding of the President's executive power over foreign relations.

Following the Continental Congress's example, the Act created an "Executive department" called the "Department of Foreign Affairs" and established a Secretary. ${ }^{286}$ In contrast to the prior regime where the Secretary was Congress's instrument, this new Secretary was to be wholly subordinate to the President. Reflecting the office's executive nature, the Secretary was to function as the President "shall from time to time order or instruct." ${ }^{287}$ Indeed, neither the Secretary nor the Department owed any duties to either house of Congress. Congress had cut itself out of the picture.

285. An Act for Establishing an Executive Department, To Be Denominated the Department of Foreign Affairs, ch. 4, 1 Stat. 28 (1789).

286. Id. \& 1. Subsequently, Congress added some domestic functions to the Department and renamed it the Department of State. See An Act To Provide for the Safe-Keeping of the Acts, Records and Seal of the United States, ch. 14, 1 Stat. 68 (1789).

287. An Act for Establishing an Executive Department, To Be Denominated the Department of Foreign Affairs $\$ 1$. 
Even more significantly, Congress did not assign any foreign affairs functions to the Secretary. Rather, Congress provided that the Department, the Secretary, and its inferior officer (the Chief Clerk) were to undertake whatever foreign affairs functions the President assigned them. By drafting the statute this way, Congress conspicuously conveyed its views regarding foreign affairs. First, the statute suggested congressional impotence. The statute was an implicit admission that Congress had no general power over foreign relations. Rather than codifying certain foreign policies that lacked a basis in Congress's explicit foreign affairs power (such as "Negotiate a treaty with Spain" or "Ally with Russia"), Congress created an institution and officers that were nothing but the dependent wills of the President. As Representative Theodore Sedgwick declared in the debate leading up to the Act's passage, the Secretary was "as much an instrument in the hands of the President, as the pen is the instrument of the Secretary in corresponding with foreign courts." 288

Furthermore, the statute presumed a wide executive sphere in foreign relations. Congress implicitly recognized that the President enjoyed general foreign affairs authority because its statute assumed that the President possessed preexisting foreign affairs powers. By the statute's terms, the President could entrust the Secretary with duties relating to correspondence, commissions, instructions to U.S. diplomats, negotiations with foreign countries, the receipt of memorials from foreigners, and "other matters respecting foreign affairs." ${ }^{289}$ Yet the statute in no way conveyed authority over such matters to the President and, hence, it simply cannot be read as if Congress delegated its powers to the President. Accordingly, if the President lacked residual authority over external relations, the statute would have been a nullity, because the President would have had nothing to delegate to the Secretary. In other words, if the President lacked the constitutional authority to instruct U.S. diplomats, conduct foreign correspondence, and so forth, the statute was utter nonsense. ${ }^{290}$ We have no doubt that Congress grasped the obvious fact that the Constitution itself conveyed residual foreign affairs authorities to the President. ${ }^{291}$

288. I ANNALS OF CONG. 522 (Joseph Gales ed., 1789).

289. An Act for Establishing an Executive Department, To Be Denominated the Department of Foreign Affairs $\S 1$.

290. Some might wonder whether the President's power to appoint diplomatic agents and negotiate and make treaties might somehow explain the Department's (and the Secretary's) subservience to the President. Yet the Department did far more than help negotiate treaties. The Department existed to help the President with all the minutiae of diplomacy, whether or not the matters related to treaty negotiation. Hence, the President's specific foreign affairs authority could not support all the powers that the statute assumed the President had by virtue of the Constitution. Those other authorities flowed from the President's executive power.

291. The contrast between this statute and the Treasury's organic act is stark. In the latter statute, Congress ordered the Treasury Secretary to take up a number of duties relating to public finance and public lands. An Act To Establish the Treasury Department, ch. 12, 1 Stat. 65 (1789). Although the executive might have undertaken such activities anyway, Congress could require 
Finally, the President's implied removal authority over the Secretary also suggested congressional acquiescence to the executive nature of foreign affairs. Although many denied that the President enjoyed removal authority, ${ }^{292}$ the House modified the initial draft bill to reflect the view that the President enjoyed such authority by virtue of the Constitution itself. Rather than conveying removal authority, the statute stated that the Chief Clerk would assume control of the Department's records whenever the President removed the Secretary. ${ }^{293}$ The only way that the President might have had removal authority over such an officer was if the President had a constitutional authority over foreign affairs in the first instance by virtue of the President's executive power. ${ }^{294}$

Hence, the Act establishing the Department of Foreign Affairs implicitly recognized a residual executive power in a number of ways. Rather than making the Secretary subservient to Congress, as was the case under the Articles, the Act made the Secretary the President's instrument. Moreover, the Act assumed that the President already had broad constitutional authority in foreign affairs. Finally, the Act assumed that the President could remove the Secretary. In this vital statute, Congress unmistakably acknowledged the President's residual power over foreign affairs. ${ }^{295}$

such actions by virtue of its Article I powers over public lands and finance. Thus, while Congress deployed its legislative power to create affirmative duties for the Treasury, it did not see fit to use its legislative powers over foreign affairs to direct the Foreign Affairs Department. Its reluctance to do so speaks volumes, for it suggests that Congress was aware that the President enjoyed a foreign affairs sphere (albeit limited) that no statute could infringe or limit.

292. For an exhaustive consideration of these fascinating debates, see JAMES HART, AMERICAN PRESIDENCY IN ACTION 1789, at 152-214 (1948). See also CURRIE, supra note 280, at 36-41 (discussing some difficulties in interpreting the votes in the House).

293. An Act for Establishing an Executive Department, To Be Denominated the Department of Foreign Affairs $\$ 2$.

294. Even those who vociferously argued in favor of presidential removal power could not have believed that the President enjoyed removal power over all nonjudicial officers. After all, no one argued that the President could remove individuals appointed to posts in Congress. The President was regarded as having removal authority over the three departments because each department was thought responsible for helping carry into execution the President's powers, be it control of foreign affairs, the military, or law enforcement.

295. Significantly, James Madison led the effort in the House to recognize the President's constitutional authority to remove the Secretary for Foreign Affairs. See 1 ANNALS OF CONG. 463 (Joseph Gales ed., 1789) (statement of James Madison) (identifying the Vesting Clause of Article II, Section 1 as the source of the President's power to remove the Secretary); see also Letter from James Madison to Edmund Pendleton (June 21, 1789), in 1 LETTERS AND OTHER WRITINGS OF JAMES MADISON 477, 478 (Phila, J.B. Lippincott \& Co. 1867) (stating that the prevailing view in Congress was that "the Executive power being in general terms vested in the President, all power of an Executive nature not particularly taken away must belong to that department"). 


\section{Congress Funds the Executive Department of State}

The organic act was hardly an aberration, for the manner in which Congress funded America's diplomats also speaks to its understanding of the executive's residual power over foreign affairs. Congress confirmed the executive nature of the Secretary and his Chief Clerk when it fixed their salaries in an Act for Establishing the Salaries of the Executive Officers of Government, with their Assistants and Clerks. ${ }^{296}$ Just as revealing was the Act Providing the Means of Intercourse Between the United States and Foreign Nations. ${ }^{297}$ Besides providing an annual diplomatic budget of $\$ 40,000$, the Act set maximum salaries for U.S. ministers and made the President responsible for the disbursal of funds. ${ }^{298}$ Just like the Act creating the Department of Foreign Affairs, this Act reflected a congressional acknowledgment that the Chief Executive would conduct the nation's foreign intercourse. Within limits, the President was trusted to set salaries for the officers that would help carry into execution the President's foreign affairs powers.

The process leading up to the Act confirms this reading. In his first State of the Union Address, Washington set the wheels in motion, observing that the country's "intercourse with other nations should be facilitated by such provisions as will enable me to fulfil my duty in that respect." ${ }^{299}$ As Jefferson Powell recently remarked, "[i]t is difficult to read this public address to mean anything other than that it is the President's duty-not Congress's" - to direct foreign intercourse. ${ }^{300}$

While debating the funding bill, House members also confirmed the President's residual foreign affairs power. According to newspaper accounts, a handful of representatives argued that because the Senate had roles in appointing emissaries and in treaty-making, it ought to have a check on the ranks and salaries of diplomats. ${ }^{301} \mathrm{~A}$ smaller number argued that Congress should create diplomatic posts and set grades. ${ }^{302} \mathrm{~A}$ much

296. Ch. 13, 1 Stat. 67 (1789) (emphasis added).

297. Ch. 22,1 Stat. 128 (1790).

298. Id. $\$ 1$.

299. George Washington, First Annual Message (Jan. 8, 1790), in GEORGE WaSHINGTON 467, 468 (W.B. Allen ed., 1988) (emphasis added).

300. Powell, supra note 8 , at 1478 .

301. See 12 DOCUMENTARY History of THE FIRST FEDERAL CONGRESS OF THE UNITED STATES OF AMERICA 69, 71, 74, 75 (Helen E. Veit et al. eds., 1994) (motion of Rep. Lee) (moving to require the President to draw money only with the Senate's advice and consent); $12 \mathrm{id}$. at 76, 78 (comments of Rep. Stone); 12 id. at 79 (comments of Rep. Sherman).

302. See $12 \mathrm{id}$. at 31 (statement of Rep. Jackson) (arguing that Congress should decide what nations would be sent emissaries); $12 \mathrm{id}$. at 37 (statement of Rep. Sherman) (arguing that the legislature ought to decide the number of ministers); see also 12 id. at 71 (summarizing arguments). Still others argued that Congress had to fix statutorily the salaries of emissaries rather than delegate those decisions to the executive. See 12 id. at 80-81, 88 (remarks of Reps. Scott and Jackson). 
larger number, however, regarded the "intercourse with foreign nations [as] a trust specially committed to the President." ${ }^{303}$ After Congress had supplied the necessary funds, the President would resolve how best to fulfill his constitutional commitment. ${ }^{304}$ Representative Smith pointed out that the Senate's appointment and treaty powers did not mean that the Senate would have some special power over emissaries. ${ }^{305}$ In fact, Senate-confirmed diplomats might never negotiate a treaty; special envoys not confirmed by the Senate might negotiate instead. ${ }^{306}$ Smith also observed that if the Senate had a special role in fixing diplomatic salaries because of its appointment check, it should set salaries for all federal officers ${ }^{307}$ Because the Senate clearly lacked such authority over executive officers generally, Smith's argument was an effective counter. Representative Benson put the proexecutive argument best when he reportedly declared that it would be wrong to blend the Senate and the President together beyond those cases where the Constitution itself required power sharing. ${ }^{308}$ " $[\mathrm{I}] \mathrm{n}$ any business whatever of an executive nature, they had no right to [create a special Senate role] any more than they had the right to associate" a House committee with the President. ${ }^{309}$

The executive's defenders won the day because they had the winning arguments. Neither the Senate nor Congress was granted special checks on funds disbursal or empowered to establish diplomatic rank. Moreover, neither this Act nor any other mandated diplomatic relations with certain countries or established foreign embassies. Further, we know of no act that appropriated funds for any diplomatic initiatives that Congress might wish to direct. Congress kept clear of such executive details. Congress appropriated funds, set maximum salaries, and left the executive details to the President. The Chief Executive would decide where to send emissaries and their ranks. ${ }^{310}$

303. $12 \mathrm{id}$. at 72.

304. See 12 id. at $72,74-75$.

305. 12 id. at $79-80$.

306. See id.

307. Id.

308. See 12 id. at 81 .

309. $I d$.

310. We do not doubt that Congress can actually set the salaries of U.S. diplomats. We merely point out that Congress has no authority to determine where diplomats must go. Nor does Congress have the authority to prohibit the President from sending an emissary. Moreover, although Congress has broad appropriations power, there are limits to how Congress can use this power as a means of influencing another branch's powers. For instance, just as Congress probably cannot pass an appropriation declaring that no funds allocated to the judiciary can be used to make a particular judgment, Congress likewise probably cannot declare that no funds shall be used to recognize a foreign state or to communicate with a particular country. 


\section{The Executive Seeks Advice on His Executive Power}

While Congress debated how to fund foreign intercourse, the President anxiously monitored the proceedings. Apparently, Washington regarded the setting of diplomatic rank as an executive power. To gauge whether his views were sound, he sought outside counsel. Secretary of State Thomas Jefferson's opinion on the matter stands out as a notable confirmation of our residual theory. Jefferson observed that the Constitution declared that " 'the executive powers shall be vested in the President,' submitting only special articles of it to a negative by the senate." ${ }^{311}$ Having laid out the relevant text-the Executive Power Clause-Jefferson proceeded to illustrate its implications:

The transaction of business with foreign nations is executive altogether; it belongs, then, to the head of that department, except as to such portions of it as are specially submitted to the senate. Exceptions are to be construed strictly; the constitution itself... has taken care to circumscribe this one within very strict limits; for it gives the nomination of the foreign agent to the president, the appointment to him and the senate jointly, and the commissioning to the president. ${ }^{312}$

Jefferson thus made clear that he viewed the Senate's appointment check on emissaries as an exception to the Constitution's executive power over transactions with foreign nations.

Regarding the specific issue, Jefferson noted that destination and rank logically preceded both nomination and confirmation, and thus there could be no claim that the Senate had a constitutional right to set these traits by virtue of its power to confirm appointments: ${ }^{313}$

The senate is not supposed by the constitution to be acquainted with the concerns of the executive department. It was not intended that these should be communicated to them; nor can they, therefore, be qualified to judge of the necessity which calls for a mission to any particular place, or of the particular grade, more or less marked, which special and secret circumstances may call for. All this is left to the president; they are only to see that no unfit person be employed. $^{314}$

311. Thomas Jefferson, Opinion on the Powers of the Senate (Apr. 24, 1790), in 5 THE WRITINGS OF THOMAS JEFFERSON, supra note 207, at 161, 161 (1895).

312. $I d$.

313. Id. at 161-62.

314. Id. at 162 . 
In other words, because the Senate's appointment role was but an exception to the executive power, there could be no constitutional basis for its intrusion into other executive areas. The President had the residual executive power and the Senate had but a specific (albeit potent) check.

Jefferson's opinion is just one of the many instances in which he confirmed that the President enjoyed formidable foreign affairs powers by virtue of his executive power. Although he erroneously quoted the Vesting Clause (he spoke of "executive powers"), he clearly regarded the rest of Article II as merely a list that limits and clarifies the general grant of executive power. ${ }^{315}$ There is no other way of making sense of his claim that the Senate's executive roles in treaties and appointments were "exceptions" to be construed strictly against the general rule. The existence of these limited checks did nothing to call the underlying executive power into question, nor could they be construed as reasons to permit other checks on the President.

Washington was not content with the opinion of his constitutionally subordinate Secretary. He also sought the opinions of luminaries from the other two branches. He turned to Supreme Court Chief Justice John Jay and Representative James Madison. Washington deemed Jay's opinion consistent with Jefferson's. ${ }^{316}$ This was no small matter because, besides being one the nation's premier lawyers and the Chief Justice of the Supreme Court, Jay had been the Secretary for Foreign Affairs. If two Secretaries charged with helping steer foreign relations concluded that foreign relations was an executive matter, Washington had powerful support for his view.

Washington also secured James Madison's favorable opinion. Washington wrote in his diary that Madison's

opinion coincides with Mr. Jays and Mr. Jeffersons-to wit-that they have no Constitutional right to interfere with either, \& that it might be impolitic to draw it into a precedent their powers extending no farther than to an approbation or disapprobation of the person nominated by the President all the rest being Executive and vested in the President by the Constitution. ${ }^{317}$

Washington's entry suggested that Madison relied on the Executive Power Clause. Because the Senate's powers extended "no farther than to an approbation or disapprobation of the person nominated by the President," destination and rank were "Executive and vested in the President by the

315. Cf. THE FEDERALIST No. 41, supra note 113 , at 266 (James Madison) (observing that it is common to grant a broad power and then qualify it with additions and limitations).

316. 6 The Diaries OF GeORGE Washington 68 (Donald Jackson \& Dorothy Twohig eds., 1979).

317. Id. 
Constitution." ${ }^{318}$ Accordingly, the Senate had "no Constitutional right to interfere with either" the destination or rank of U.S. diplomats. ${ }^{319}$ In a dispassionate moment, unclouded by partisan feelings, Madison adopted our residual theory of the executive power.

The funding debate of 1790 not only stands out as another notorious instance in which Congress acknowledged the President's residual foreign affairs powers, it also marks another instance in which the executive itself asserted that it enjoyed foreign affairs powers beyond those squarely enumerated in Article II. Unless the Senate or Congress could point to specific constitutional language deviating from executive control (such as the Treaty Clause or the power to declare war), the President would ordinarily enjoy foreign affairs powers by virtue of his executive power. Although there were exceptions to the executive power, they were to be construed strictly.

\section{The Chief Diplomat Controls His Department}

So much for the organic statute and the funding debate. But what of the practices? Was Washington the true Secretary of State? Or did Washington and Jefferson recognize that the Secretary had a sphere of foreign relations authority that the President simply could not breach? As developed below, the Chief Executive directed the nation's foreign affairs subject to the Constitution's exceptions to his executive power. Moreover, Jefferson knew that he was the President's Secretary. In every major matter, he sought the President's official direction.

In correspondence concerning whether Jefferson would serve as the Secretary of State, both sides recognized that the Secretary was the President's subordinate. Hoping to entice Jefferson from Paris, Washington observed that the Department would involve "many of the most interesting objects of the Executive Authority." ${ }^{320}$ Although Jefferson's response was equivocal, he made clear that if the President insisted, he would be the President's trusted executive subordinate: " $[\mathrm{M}] \mathrm{y}$ chief comfort will be to work under your eye, my only shelter the authority of your name, and the wisdom of measures to be dictated by you and implicitly executed by me." ${ }^{321}$ In his reply letter, Washington noted that he could not provide much detail about his administration's intended foreign policies. "The necessary arrangements with regard to our intercourse with Foreign Nations

318. Id.

319. Id.

320. Letter from George Washington to Thomas Jefferson (Oct. 13, 1789), in 30 THE WRITINGS OF GEORGE WASHINGTON, supra note 281 , at $446,446$.

321. Letter from Thomas Jefferson to George Washington (Dec. 15, 1789), in 5 THE WRITINGS OF THOMAS JEFFERSON, supra note 207, at 140, 141 (1895). 
have never yet been taken up on a great scale by the Government: because the Department [of State] ... has never been properly organized, so as to bring the business well and systematically before the Executive." 322 In each of these letters, the writer confirmed that the President had broad authority over foreign affairs. In his last letter, Washington intimated that the Secretary would shape U.S. foreign policy by enabling the Chief Executive to make better decisions.

In practice, Washington controlled Jefferson, assertively wielding his executive power over foreign affairs. For example, Washington directed foreign negotiations and personally selected diplomats. ${ }^{323}$ Washington even secretly corresponded with Gouverneur Morris, ambassador to France: The latter dispatched "official" letters to Jefferson and penned more frank descriptions to his constitutional superior. ${ }^{324}$ Jefferson, by way of contrast, never usurped his superior's authority and instead assumed the role of loyal executive subordinate in his official transactions. ${ }^{325}$ Although Jefferson often disagreed with and was repeatedly overruled by the President, he nevertheless signed dispatches, the substance of which he vigorously opposed. ${ }^{326}$ Indeed, during the internecine battle between Jefferson and Hamilton, Jefferson rhetorically asked Washington to judge whether Jefferson had carried out the President's policies "as sincerely as if they had been my own, tho' I ever considered them as inconsistent with the honor \& interest of our country." ${ }^{327}$ Given Washington's dominance, James Hart claims that Washington was his own Foreign Secretary ${ }^{328}$ and that Jefferson and his successors were secretaries in the most literal sense of the term. ${ }^{329}$ Although these principal executive officers advised and corresponded on behalf of the Chief Executive, they were not constitutional principals in the strict sense. They were instead constitutional agents. ${ }^{330}$

322. Letter from George Washington to Thomas Jefferson (Jan. 21, 1790), in 30 THE WRITINGS OF GEORGE WASHINGTON, supra note 281, at 509, 511 .

323. LEONARD D. WHITE, THE FEDERALISTS 131 (1948).

324. See SOFAER, supra note 280 , at 78.

325. In his private capacity, Jefferson associated with many who were strongly critical of the administration. Additionally, he sometimes actively encouraged (and improperly funded) criticism of Washington's administration. Yet for the most part, in his official transactions, Jefferson carried out Washington's orders. See WHITE, supra note 323, at 131.

326. Id.

327. Letter from Thomas Jefferson to George Washington (Sept. 9, 1792), in 7 THE WORKS OF THOMAS JEFFERSON, supra note 200, at 136, 140.

328. WHITE, supra note 323, at 36; see also PLISCHKE, supra note 186, at 43 (observing that Washington regarded himself as the primary foreign affairs decisionmaker and was regarded as his own Secretary of State); id. at 59 (labeling Washington as the "foreign-policy-maker-inchief").

329. WHITE, supra note 323, at 131.

330. As noted earlier, as a matter of law the Secretary could hardly act as a free agent because the organic act did not convey any authority to him. Instead, the Secretary only had such authority when the President delegated it to him. See supra Subsection VII.A.2. 
As one might expect, Washington's control extended beyond the secretaries. In fact, he treated the U.S. diplomatic corps as an extension of his will. Washington sometimes corresponded directly with U.S. ministers (as with Gouverneur Morris ${ }^{331}$ ). Other times he merely reviewed proposed instructions drafted by Jefferson. ${ }^{332}$ Besides directing U.S. diplomats in their enunciation of U.S. policy and in their negotiations, Washington also shuffled them (usually with the concurrence of the Senate) between countries $^{333}$ and removed them. After the United States requested the recall of French Minister Edmond Charles Genet, the French sought the recall of Gouverneur Morris. The request was made to Washington and he unilaterally obliged. ${ }^{334}$ Later, Washington removed James Monroe from France, feeling that Monroe had a French bias and was untrustworthy. ${ }^{335}$ In directing and removing U.S. diplomats, Washington was in no sense usurping foreign affairs powers lodged elsewhere. Rather, he was supervising how others helped effectuate his constitutional power. He had the residual executive power over foreign affairs, and because Congress lacked the textual authority to instruct, correspond with, or remove U.S. diplomats, the President enjoyed those powers.

Washington went beyond merely instructing and firing diplomats, however. He also effectively created them. Congress never created foreign diplomatic posts. Rather, Washington erected all of America's diplomatic postings by merely nominating individuals to serve as a U.S. minister or agent to a foreign court. If the Senate confirmed the nominee, Washington had created a foreign post. ${ }^{36}$ Washington also felt free to dispatch unilaterally emissaries to foreign nations without the advice (and certainly without the consent) of the Senate. Early on, Washington constituted Gouverneur Morris as a "private agent" to talk to the English regarding

331. SOFAER, supra note 280 , at 78.

332. See, e.g., Letter from George Washington to Thomas Jefferson (July 30, 1791), in 31 THE WRITINGS OF GEORGE WASHINGTON, supra note 281, at 331 (reviewing instructions to William Short, Minister Resident at the Hague).

333. See PLISCHKE, supra note 186 , at 48 tbl.2.2.

334. Id. at 64 n.25.

335. See SOFAER, supra note 280 , at $65 \mathrm{n}$.*.

336. We are not sure whether the Constitution permits the President to appoint to a diplomatic post in the absence of a statute first creating that diplomatic post. See U.S. CoNST. art. II, $\$ 2$, cl. 2 (providing that the President can appoint Supreme Court Justices, ambassadors, ministers, consuls, and other officers of the United States that "shall be established by Law"). Some scholars may assume that the President can only appoint diplomatic officers to posts that have been created by statute because that is the familiar rule in the domestic context. On the other hand, it is possible to read the Appointments Clause as providing the President the power to appoint to the Supreme Court and to diplomatic posts even in the absence of a statute creating these posts. Id. art. II, $\S 2, \mathrm{cl}$. 2 . If one construes the phrase "established by law" as only applying to "all other officers of the United States," then the President would be able to appoint diplomats even when there were no statutorily authorized posts. 
implementation of the peace treaty and a possible commerce treaty. ${ }^{337}$ Morris was to speak for the nation on "the Authority and Credit of" the very letter spelling out his assignment. ${ }^{338}$ Similarly, the President sent an emissary to Portugal to lay the groundwork for a formal exchange of emissaries. ${ }^{339}$ Washington's practice of creating diplomatic posts and dispatching envoys is instructive. We believe that neither he nor Congress was troubled by his actions because people generally understood that he enjoyed the residual power of deciding where to send American emissaries.

\section{Conclusion: The Chief Diplomat's Department}

After ratification, the President's control of the foreign affairs bureaucracy was astonishingly complete. In a sharp break with practice under the Articles of Confederation, Congress relinquished the reins of control and acknowledged that the President would superintend the foreign affairs machinery. Congress abandoned its practice of directing the nation's diplomats. It did not even mandate any particular diplomatic duties. Instead, all was left to the President's discretion. The President created the diplomats, instructed them, and recalled them. Moreover, Congress created a Secretary of State who enjoyed absolutely no statutory authority over foreign affairs. Instead, he was but a receptacle for whatever foreign affairs authority the President might see fit to deposit. In other words, Congress created the Secretary to assist the President in the execution of the President's constitutional powers over foreign affairs.

Not surprisingly, the President had the same view of his executive officers: They existed to help him carry out his executive power. In a letter to Count de Moustier, the French minister resident at New York, Washington declined Moustier's request that he personally negotiate a treaty with France. There were time-tested forms for conducting foreign affairs, including leaving subordinate diplomats to negotiate directly with

337. Letter from George Washington to Gouverneur Morris (Oct. 13, 1789), in 30 THE WRITINGS OF GEORGE WASHINGTON, supra note 281 , at $439,440$.

338. $30 \mathrm{id}$. at 440 . Only after the mission ended in failure did Washington inform the Senate of his diplomatic gambit. See Letter from George Washington to the Senate (Feb. 14, 1791), in 2 DOCUMENTARY History OF THE FIRST FEDERAL CONGRESS OF THE UNITED STATES OF AMERICA 116 (Linda Grant De Pauw ed., 1974). Washington also sent a much less complete letter to both the Senate and the House that mentioned his initiative and its failure. See Letter from George Washington to the Senate and House (Feb. 14, 1791), in 3 DOCUMENTARY HISTORY OF THE FIRST FEdERAL CONGRESS OF THE UNITEd STATES OF AMERICA, supra, at 713 (1977). Washington's less complete letter to the House likely reflects his view that the House was not the Senate's equal in foreign affairs.

339. See Letter from George Washington to the Senate (Feb. 18, 1791), in 31 THE WRITINGS OF GEORGE WASHINGTON, supra note 281, at 219, 219-21. In subsequent years, Washington sent John Jay and Thomas Pinckney to England, but in these instances, he first sought Senate confirmation of the offices. See 1 JOURNAL OF THE EXECUTIVE PROCEEDINGS OF THE SENATE OF THE UNITED STATES OF AMERICA 151-52, 164 (Washington, Duff Greene 1828). 
foreign ministers. More practically, Washington simply could not conduct all executive business himself. "The impossibility that one man should be able to perform all the great business of the State, I take to have been the reason for instituting the great Departments, and appointing officers therein, to assist the supreme Magistrate in discharging the duties of his trust." 340 Although the Constitution empowered him to direct much of foreign affairs, Washington knew he could hardly do so without the able assistance of America's diplomats.

The advocates of congressional primacy cannot explain what must seem like abject legislative surrender coupled with executive usurpation. If the Constitution endowed Congress with foreign policy leadership, why did Congress repeatedly endorse presidential control and why did the executive act even without congressional authorization? Likewise, those who believe that the Constitution was radically incomplete cannot explain why Congress conceded the President's significant residual foreign affairs authority from the beginning. If the Constitution said nothing, why did Congress and the President repeatedly evince a common understanding that the executive was in charge of those foreign affairs powers not specifically granted to the President?

Riding on Jefferson's coattails, we have the answers. Our residual theory of the executive power over foreign affairs neatly explains much of what is otherwise simply unfathomable. The President enjoyed the executive power over foreign affairs subject to those exceptions enumerated in the Constitution. Because Congress no longer enjoyed the constitutional authority to control diplomatic instruments, the President had such authority by virtue of his executive power. Jefferson put it best in 1790: "The transaction of business with foreign nations is executive altogether .... [The Constitution's] [e]xceptions [to the executive power] are to be construed strictly ...." 341

\section{B. The President's Control over the Recognition of Governments and the Reception of Emissaries}

We turn from Washington's dominance of the instruments of foreign affairs to his complete control of the recognition of governments and the reception of emissaries. Once again, while the alternative theories cannot make sense of Washington's practices, our residual theory of the executive power over foreign affairs explains how the President came to have such powers.

340. Letter from George Washington to Eléonor François Élie (May 25, 1789), in 30 THE WRITINGS OF GEORGE WASHINGTON, supra note 281, at 333, 334.

341. Thomas Jefferson, Opinion on the Powers of the Senate (Apr. 24, 1790), in 5 THE WRITINGS OF THOMAS JEFFERSON, supra note 207, at 161, 161 (1895). 


\section{Recognition of Foreign Governments and Emissaries}

The crucial question of whether to recognize a putative government and receive its agent arose in the early years of the Washington Administration. In September 1792, the French National Convention abolished the monarchy and declared France a republic. In the months to come, the United States faced a dilemma: Would it recognize the French Republic and thereby repudiate Louis XVI's regime? Although many know that the nation recognized the new republic and welcomed its emissary, who made these choices on behalf of the nation reflects rather well on the theory that the President enjoys a residual power over foreign affairs.

In April 1793, Washington posed thirteen queries to his cabinet regarding the nation's relationship with France. Washington's second question asked whether the United States ought to receive a minister from the French Republic. Washington's twelfth question was closely related: Should the future Regent of France send a minister to the United States, ought he receive the Regent's minister? Apparently, the cabinet agreed that Washington should receive Genet, France's new emissary. ${ }^{342}$ Regarding the related question, Jefferson responded that the government should receive a minister from a French Regent only when the French nation-by that he meant the Republic-created such an office. ${ }^{343}$ As is well-known, Washington decided to receive Genet.

We believe Washington's actions reflected a consensus shared by Washington, his cabinet, and Congress. By posing these questions and then acting on the answers, Washington clearly believed that he determined which regimes to recognize. ${ }^{344}$ The cabinet's unanimity on Genet's reception similarly underscored the underlying assumption about recognition authority: It was an executive power. Neither Washington nor his cabinet believed that Washington had to consult with the Senate or Congress generally. In fact, although Washington asked whether he ought to convene Congress, ${ }^{345}$ the cabinet unanimously concluded that it was unnecessary. ${ }^{346}$ Finally, Congress never purported to tell Washington which

342. Thomas Jefferson, Anas (Apr. 18, 1793), in 1 THE Writings OF ThOMAS JEFFERSON, supra note 207, at 226, 226-27 (1892).

343. Id. This was Jefferson's clever way of dismissing any suggestion that Washington ought to receive a representative that might be sent by a regent acting on behalf of the monarchy.

344. It also bears emphasizing that in recognizing the French Republic, Washington also exercised the power to de-recognize the French monarchy. Hence while one could imagine a system in which one entity could recognize govemments only after another entity decided to stop recognizing a prior or existing government, Washington recognized that the Constitution had not split those closely related powers. He could exercise both under his executive power.

345. George Washington, Questions Submitted to the Cabinet by the President (Apr. 18, 1793), in 32 THE WRITINGS OF GEORGE WASHINGTON, supra note 281 , at 419, 420.

346. Thomas Jefferson, Anas (Apr. 18, 1793), in 1 THE WRITINGS OF THOMAS JEFFERSON, supra note 207, at 226, 227 (1892). 
countries or governments to recognize. In our view, Congress never dictated which countries or governments to recognize because it understood that the Constitution had shifted the recognition power from Congress to the President. ${ }^{347}$

The new executive power also decided whether to issue exequaturs to foreign consuls. By international practice, foreign consuls were to receive an exequatur-a document from the host country that permits the consul to take up consular functions-from the executive. During the Articles period, Congress had formally recognized consuls but had left exequatur issuance to the executives of those states where the consul had jurisdiction. ${ }^{348}$ With the change in regime, however, the new executive took center stage. The President not only signed exequaturs, ${ }^{349}$ he also set policy respecting their issuance. ${ }^{350}$ Jefferson made this clear in letters to France's ministers to the United States. To Jean Baptiste Ternant, Jefferson noted the President would only issue exequaturs that were consistent with the commission issued by the foreign country. If a French commission spelled out a particular jurisdiction for a consul, the President's exequatur would reference the limited jurisdiction. ${ }^{351}$ Similarly, Jefferson curtly instructed Genet that all French commissions must be addressed to the President or the United States; if they were not, the executive branch would not issue exequaturs for the proposed consuls. ${ }^{352}$ Jefferson also told Genet that pursuant to Washington's instructions, Jefferson was not at liberty to prove that the Constitution "has ascribed to [the President] alone the admission or interdiction of foreign agents." ${ }^{353}$ Although Jefferson was not at liberty to

347. Although we know of no event where Washington unambiguously decided to recognize the existence of a state or chose to end recognition of a state (as opposed to recognizing a particular government), we think that Washington implicitly made decisions about which states to continue recognizing in the early days of his administration. He decided to keep U.S. cmissaries posted in various countries, and he also decided which emissaries he would receive. Although one might view Washington's practices as merely continuing the status quo (and thus not indicative of any power that he might have had as a result of his executive power), we prefer to view Washington as having made choices about which states to recognize. After all, there was no constitutional or statutory requirement that he continue past recognition practices.

348. See 21 JOURNALS OF THE CONTINENTAL CONGRESS, 1774-1789, at 940-41 (Gaillard Hunt ed., 1912) (establishing the practice of passing an Act of Recognition for consuls and allowing state executives to issue exequaturs).

349. See Letter from George Washington to the Secretary of State (Oct. 11, 1793), in 33 THE WRITINGS OF GEORGE WASHINGTON, supra note 281, at 116, 116 (observing that he had signed the exequatur for "Mr. Dannery," the new French consul for Boston).

350. In issuing exequaturs, Washington played a role similar to the one he played when issuing commissions to U.S. officials. Similar to a commission, an exequatur was a document evidencing a government's willingness to allow an emissary to serve as consul.

351. See Letter from Thomas Jefferson to Jean Baptiste Ternant (Oct. 23, 1792), in 7 THE WORKS OF THOMAS JEFFERSON, supra note 200 , at $167,168$.

352. Letter from Thomas Jefferson to Edmond Charles Genet (Dec. 9, 1793), in 8 THE WORKS OF THOMAS JEFFERSON, supra note 200, at 89,91.

353. Letter from Thomas Jefferson to Edmond Charles Genet (Nov. 22, 1793), in 8 THE WORKS OF THOMAS JEFFERSON, supra note 200, at 73, 74. 
reveal why the admission of foreign agents was a presidential prerogative, we are under no such constraints. The President could formally admit foreign agents because he had the residual executive power over foreign affairs.

\section{Dislodging Foreign Emissaries}

We already have highlighted Washington's assumption of the authority to recall U.S. diplomats. Here we recount how President Washington exercised his residual executive power to request the recall of foreign agents and to unilaterally revoke their credentials.

We know of two instances in the nation's early years in which the nation sought the recall of foreign diplomats. When compared to each other, they are quite revealing. In 1788, Congress exercised its executive power by requesting that France recall Count de Moustier. Apparently, members sought his recall because they thought him haughty and immoral. ${ }^{354}$ In 1793, however, Washington seized the initiative by requesting that France recall Genet after the latter repeatedly acted in a manner inconsistent with his diplomatic office. ${ }^{355}$ The contrast itself is highly suggestive, but when one digs a little deeper, the latter episode reveals much more.

After his cabinet debated whether he should demand Genet's recall or merely make a request to France, Washington sided with Jefferson and ordered that the letter to the Committee of Public Safety (the French executive) lay out the facts and allow the French to recall Genet. As a matter of courtesy, Jefferson sent Genet a copy of the recall request. The note accompanying the copy of the request informed Genet that he could continue on as the French minister in the meantime if he restrained himself "within the limits of the law as heretofore announced to you." 356 Notwithstanding his precarious position, Genet showed little restraint. He challenged Washington's ability to request his recall, arguing that only Congress could do that ${ }^{357}$ Unfortunately for Genet, the French government thought otherwise. Three days after Gouverneur Morris delivered the letter requesting Genet's recall, the French agreed. ${ }^{358}$ France understood who

354. HaRRY AMmon, THE Genet Mission 23 (1973).

355. See id. at 107-09. As recounted elsewhere in this Article, Genet had armed French privateers, recruited Americans to participate in the war in contravention of the Neutrality Proclamation, established French prize courts in America, defied the President, interfered in domestic politics, and lectured Jefferson on the U.S. Constitution. See infra Section VII.E.

356. Letter from Thomas Jefferson to Edmond Charles Genet (Sept. 15, 1793), in 8 THE WORKS OF THOMAS JEFFERSON, supra note 200, at 46, 47.

357. Letter from Thomas Jefferson to Edmond Charles Genet (Sept. 18, 1793), in 1 American State Papers, Foreign Relations 172, 172-74 (photo. reprint 1998) (Walter Lowrie \& Matthew St. Clair Clarke eds., Washington, Gales \& Seaton 1833).

358. See AMMON, supra note 354, at 156. 
could make such requests on behalf of the United States even if its minister did not. France's acquiescence vindicated Jefferson's claims that the U.S. executive could "interdict," i.e., reject, foreign agents.

Although a recall request was the delicate means of dislodging foreign officials who acted contrary to their diplomatic status, more blunt means were available. When circumstances required, the Washington Administration simply revoked the credentials of foreign officials. On at least two occasions, the President exercised his residual power and unilaterally revoked exequaturs of foreign consuls. Antoine Duplaine, French Vice-Consul for Boston, had prevented a U.S. marshal from serving process on a vessel. Even worse, Duplaine led an armed force that seized a vessel in the custody of the marshal after the latter had arrested the ship pursuant to process issued by a federal court. ${ }^{359}$ Recounting his responsibility for executing federal law, Washington revoked Duplaine's exequatur ${ }^{360}$ Washington similarly revoked the exequatur of Thomas William Moore, British Vice-Consul for Rhode Island, in 1795 . $^{361}$ Washington understood that he not only issued the exequaturs; he also could revoke them when he felt it appropriate.

In letters to Genet, Jefferson outlined the international and domestic law basis for the executive's ability to send foreign emissaries home:

[E]very foreign agent depends on the double will of the two governments, of that which sends him, and of that which is to permit the exercise of his functions within their territory; and when either of these wills is refused or withdrawn, his authority to act within that territory becomes incomplete. By what member of the government the right of giving or withdrawing permission is to be exercised here, is a question on which no foreign agent can be permitted to make himself the umpire. It is sufficient for him, under our government, that he is informed of it by the executive. ${ }^{362}$

In a short series of powerful sentences, Jefferson implicitly confirmed his earlier claim that the Constitution "has ascribed to [the President] alone

359. Letter from Thomas Jefferson to James Madison (Sept. 1, 1793), in 8 THE WORKS OF THOMAS JEFFERSON, supra note 200 , at 11,11 .

360. See Letter from Thomas Jefferson to Antoine Duplaine (Oct. 3, 1793), in THOMAS JEFFERSON PAPERS, http://memory.loc.gov/mss/mtj/mtjl/019/0700/0709.jpg.

361. See Letter from George Washington to Timothy Pickering (Sept. 28, 1795), in 34 THE WRITINGS OF GEORGE WASHINGTON, supra note 281 , at 318,319 n.71. Foreign governments also understood the President's power to revoke credentials. After the Dutch minister resident in the United States dismissed a Dutch consul, he requested that Washington revoke the consul's exequatur as well. Washington described himself as caught between "Scilla and Charibdis" because it appeared that the request for revocation related to a dispute regarding a Dutch revolution. See Letter from George Washington to Edmund Randolph (Apr. 26, 1795), in 34 THE WRITINGS OF GEORGE WASHINGTON, supra note 281 , at $183,184 \mathrm{n} .73$.

362. Letter from Thomas Jefferson to Edmond Charles Genet (Dec. 9, 1793), in 8 THE WORKS OF THOMAS JEFFERSON, supra note 200, at 89, 90. 
the admission or interdiction of foreign agents." 363 Acting alone, the President could judge which agents to receive, which to reject, and which to dislodge.

Hence, although we know of no instance in which Washington resorted to the indelicate unilateral revocation of diplomatic credentials (as opposed to consular exequaturs), we have no doubt that Washington would have exercised such a power had circumstances warranted. In particular, had France not dismissed Genet, Washington surely would have revoked Genet's credentials. ${ }^{364}$ Nations must be able to dismiss diplomats who act contrary to their diplomatic status. We believe that the events of the Washington Administration confirm that the President exercises that power on behalf of the nation.

It could be said that a few of the powers canvassed above flow from the President's specific power to receive ambassadors and other public ministers. ${ }^{365}$ Yet the power to recognize a government or a nation is analytically distinct from the limited reception power. Just because one can greet messengers, it does not logically follow that one can decide which messengers to receive and whether one will receive messages or messengers only from particular countries or governments. ${ }^{366}$ Further, it hardly follows that because the President can receive diplomats he can also request their recall and revoke their credentials.

Moreover, the power to issue and revoke exequaturs can hardly flow from the power to receive diplomats. In two instances, the Constitution uses the phrase "Ambassadors other public Ministers and Consuls"-in the context of appointments ${ }^{367}$ and in laying out the Supreme Court's original jurisdiction. ${ }^{368}$ The President's reception power, however, extends only to "Ambassadors and other public Ministers." ${ }^{669}$ Hence, the power to receive, reject, and dismiss consuls simply cannot flow from the reception power because the latter power does not, by its terms, extend to consuls.

Accordingly, aside from Article II, Section 1, there is no sound textual basis for Washington's exercise of the powers to recognize governments or dismiss foreign agents. That being the case, legislative primacists and nontextual executive primacists are at a loss to explain Washington's

363. Letter from Thomas Jefferson to Edmond Charles Genet (Nov. 22, 1793), in 8 THE WORKS OF THOMAS JEFFERSON, supra note 200, at 73, 74.

364. Indeed, Jefferson's warning to Genet suggested that if Genet continued to defy Washington, the latter might revoke Genet's credentials even before France had replied to Washington's request. See supra note 347 and accompanying text.

365. U.S. CONST. art. II, \&3.

366. See infra note 471 and accompanying text (discussing Madison's claim that the President could not claim a right to refuse to receive an ambassador from his Article II, Section 3 powers).

367. U.S. CONST. art. II, § 2, cl. 2.

368. Id. art. III, \& 2, cl. 2.

369. Id. art. II, $\$ 3$. 
assumption of these authorities. In contrast, our residual theory explains why the President's authority over recognition and foreign agents goes well beyond the narrow reception power. Given that Congress lacks the authority to dictate with whom the nation will have relations and who can serve as an appropriate representative from a foreign government, the President has that authority by virtue of the executive power.

\section{The President's Control over Communications}

As many of the incidents recounted above indicate, Washington spoke for the United States when communicating with foreign countries. In this Section, we recount Washington's control of foreign communications. We also reveal how Congress and other countries accepted the executive's control of communications. Finally, we relate how Jefferson dealt with Genet when the latter denied that Washington spoke for the nation.

In the early days of the new administration, Washington assumed control over foreign communications. We have already discussed Jay's illuminating letter to the American agent in Morocco in which Jay instructed the agent that communications to the United States from foreign nations would now be directed toward the President rather than Congress. ${ }^{370}$ Jay's construction of the Constitution was entirely consistent with the Chief Diplomat's because Washington also believed that he could control communications with foreign regimes. In a December 1789 letter to Muhammed Ben Abdalla, the King of Morocco, the President asserted his authority as "sole channel of official intercourse." 371 After apologizing for the delay in responding to the King's 1788 letter, the President explained that since he was "the supreme executive Authority," the King's letter had been delivered to him. ${ }^{372}$ Likewise, after reviewing a 1789 letter from Louis XVI addressed to the President and Congress, Washington informed Congress that he would respond to the letter. In the subsequent letter to Louis XVI, Washington explained that because of the new Constitution, he had the "honor of receiving and answering" the King's earlier letter. ${ }^{373}$ Washington understood that, as part of his "supreme executive authority" conveyed by Article II, Section 1, he was to correspond with foreign governments, and their letters were to be addressed to him as the nation's sole representative. ${ }^{374}$

370. See supra note 284 and accompanying text.

371. HART, supra note 292 , at 79 .

372. Letter from George Washington to the Emperor of Morocco (Dec. 1, 1789), in 30 THE WRITINGS OF GEORGE WASHINGTON, supra note 281, at 474, 474-75.

373. Letter from George Washington to the King of France (Oct. 9, 1789), in 30 THE WRITINGS OF GEORGE WASHINGTON, supra note 281 , at 431, 431-32.

374. When a letter from the President of the Assembly of Representatives for the Community of Paris addressed to the President and Congress arrived on Washington's desk, Washington did 
Congress never challenged the President's communications monopoly. Although members often held strong sentiments about overseas events, Congress never conveyed those sentiments directly to another country. Nor did Congress ever command the President to convey certain sentiments to foreign countries, as the Continental Congress had commanded its Secretary for Foreign Affairs under the Articles. ${ }^{375}$ Instead, Congress adopted resolutions that must seem odd to modern observers of foreign affairs. Rather than passing a resolution that merely expressed the congressional view (or the view of the House or the Senate), each chamber beseeched the President to convey a message to the relevant foreign government. For instance, after learning that the French King had accepted a new constitution, the House and Senate "requested" that the President express the sincere interest of the chambers "in his answer" to France's notification. ${ }^{376}$ On another occasion, the Senate and the House "requested" the President to respond favorably to a letter from the notorious Committee of Public Safety. ${ }^{377}$ Finally, upon learning that the French Republic had presented its colors, the House requested the President to convey its sentiments to France. ${ }^{378}$

not feel authorized to open the lettcr. See Senate, Pamphlets from France (Dec. 8, 1790), in GEORGE WASHINGTON PAPERS, http://memory.loc.gov/mss/mgw/mgw2/025/2491 128.jpg. On the other hand, he did open a letter that was only addressed to him from the French National Assembly. See id. Although his actions here seem to contradict his earlier-stated belief that he was to receive and respond to all foreign communications, the letter addressed to the President and Congress was a strange creature. It did not purport to be an official communication from the French government but was a letter from an official of a local assembly. See Letter from Thomas Jefferson to William Smith (Feb. 19, 1791), in 5 THE WRITINGS OF THOMAS JEFFERSON, supra note 207, at 290, 292 (1895) (observing that the President had received letters from the National Assembly of France and from the Community of Paris). Because the letter was not an official communication from a foreign government, Washington had no constitutional right to open and respond to the letter. Hence, out of deference to Congress, he sent it to the Senate.

Notwithstanding that the letter was addressed to both the President and Congress, the Senate returned the letter to Washington and advised that he could open the letter with "more propriety." Senate, Pamphlets from France, supra. Washington directed Jefferson to open the letter, and Jefferson reported that Paris, "that respectable city," had conveyed its condolences following the death of Benjamin Franklin. See Letter from Thomas Jefferson to George Washington (Dec. 9, 1790), in 5 THE WRITINGS OF THOMAS JEFFERSON, supra note 207, at 258, 258 (1895).

We believe that Washington went to extraordinary lengths to avoid offending Congress, but nothing in this episode suggests that he had abandoned his view that he was the sole organ of communication between the United States and other governments. Indeed, the Senate's opinion that Washington could open the letter with "more propriety" suggested that even communications from subnational foreign units should be controlled by the President.

375. E.g., 24 JOURNALS OF THE CONTINENTAL CONGRESS, 1774-1789, supra note 193, at 5-6 (ordering Jay to send a letter to the French minister); 29 JOURNALS OF THE CONTINENTAL CONGRESS, 1774-1789, supra note 196, at 495-96 (ordering Jay to send a letter to the Spanish minister).

376. 1 ANNALS OF CONG. 456 (Joseph Gales ed., 1789).

377. 2 JOURNAL OF THE HOUSE OF REPRESENTATIVES OF THE UNITED STATES, 1789-1873, at 132 (Washington, Gales \& Seaton 1826); 2 JOURNAL OF THE SENATE OF THE UNITED STATES OF AMERICA, 1789-1873, at 68 (Washington, Gales \& Seaton 1820).

378. 5 ANNALS OF CONG. 29 (1796). 
Make no mistake, the chambers of Congress were not reluctant to express their sentiments. Although the resolutions were styled as requests, at least some proponents and opponents viewed these resolutions as nonetoo-subtle expressions of congressional perspectives. ${ }^{379}$ Notwithstanding the subtext, however, the form mattered quite a bit. For instance, when the Senate debated a resolution that requested that the President respond to a letter on "behalf of the United States," the resolution failed; but when the Senate modified the resolution to request that the President respond on "behalf of the Senate of the United States," the resolution passed unanimously. ${ }^{380}$ The modified resolution made clear that the Senate was only requesting that he convey the Senate's sentiments rather than those of the United States. While the Senate could request the former, it was in no position to request the latter. After all, neither it nor the House could speak for the United States. If neither could speak for the United States, neither could dictate how the President ought to speak on behalf of the United States. Indeed, we know of no foreign relations resolutions passed during the Washington era that asked that he convey the sentiments of the "United States." Each only beseeched the President to convey the sentiments of a particular chamber.

Toward the close of the Washington Administration, the Senate seemed reluctant even to request that the President convey the Senate's views to a foreign country. While the House made such a request upon learning of France's presentation of its flag, the Senate eliminated a request from its parallel resolution. After much debate, the Senate resolution merely informed the President of its pleasure upon learning of the receipt of the French flag. ${ }^{381}$ The Senate's debates suggest a reason for the modification. Senator Oliver Ellsworth, future Supreme Court Justice, made a powerful constitutional argument worth quoting at length:

Nothing, he contended, could be found in the Constitution to authorize either branch of the Legislature to keep up any kind of correspondence with a foreign nation .... It might be said, that this was a mere matter of ceremony and form, and, therefore, could do no harm. A correspondence with foreign nations was a business of difficulty and delicacy - the peace and tranquility of a country may hinge on it. Shall the Senate, because they may think it in one case trifling, or conceive the power ought to be placed in them, assume

379. See 5 id. at 33 (statement of Sen. Pierce Butler) (observing that there was nothing in the Constitution preventing the legislature from expressing its sentiments); $5 \mathrm{id}$. at 32 (statement of Sen. Oliver Ellsworth) (arguing that Congress should not put the President in a position of either rejecting their request or sacrificing his discretion).

380. 2 JOURNAL OF THE SENATE OF THE UNITEd STATES OF AMERICA, 1789-1873, supra note 377 , at 68 .

381. 5 ANNALS OF CONG. 28,36 (1796). 
it? [This power] is positively placed in the hands of the Executive....

Neither branch had a right to dictate to the PRESIDENT what he should answer. The Constitution left the whole business in his breast. It was wrong to place him in the dilemma of disobliging the Legislature or sacrificing his own discretion. ${ }^{382}$

Ellsworth's precise position-that the legislature cannot even request the executive to convey the legislature's own sentiments to a foreign country-is questionable. ${ }^{383}$ Nonetheless, his general argument highlights a line that Congress always saw fit to follow in the Washington years. As noted, neither chamber ever communicated directly with a foreign nation or demanded that the President convey a particular message. When either chamber actually requested that the President convey a message to a foreign country, the requests only asked that he convey the sentiments of the particular chamber. These nonbinding resolutions never urged that he convey the sentiments as if they came from the nation. Congress's posture reflected an extraordinary (but appropriate) level of deference, for the power to speak on behalf of the nation was "positively placed" with the President by virtue of the executive power. ${ }^{384}$

For those without the aid of the residual theory of foreign affairs, these legislative resolutions must seem puzzling. Each reflects an extraordinary amount of deference to the executive. Why did the House and the Senate

382. $5 \mathrm{id}$. at 32. Based on a fear that the President would have to choose between indulging Congress or expressing his own views, Ellsworth argued against even asking the President to convey the views of a chamber.

383. Even he had to admit that past practice was against him. We find it hard to regard any request, from whatever quarter, as a violation of the Constitution's allocation of executive power to the President.

Nonetheless, Washington may have agreed with Ellsworth. In March 1792, the President sought Jefferson's view on the House resolution requesting the President to convey the House's congratulations regarding the new French Constitution. See supra note 378 and accompanying text. According to Jefferson, Washington "apprehend[e]d the legislature w[oul]d be endeavoring to invade the executive." Thomas Jefferson, Anas (Mar. 12, 1792), in 1 THE WORKS OF THOMAS JEFFERSON, supra note 200 , at 163,211 . Jefferson counseled against contesting the propriety of the House resolution. "That if expressing a sentiment were really an invasion of the Executive power, it was so faint a one, that it would be difficult to demonstrate it to the public ..." $I d$. at 213. He also pointed out that the public's pro-Gallic sentiments made the arguments all the more difficult. Id . We are unaware whether Washington ever conveyed his misgivings to anyone other than Jefferson.

384. Just to be clear, this Section recounts Congress's proper acceptance of the President as the sole organ of communication. While Congress is free to pass nonbinding "sense of the Congress" resolutions about foreign affairs matters and it may ask the President to convey messages to foreign governments or peoples, it cannot purport to speak on behalf of the United States. That is part of the President's residual executive power. Nor may Congress directly receive communications from foreign governments. Those communications are properly made to the President. (Admittedly, the precise constitutional violation is hard to identify when nations attempt to bypass the President. Yet Congress should not be a willing accomplice to the foreign nation's attempt to ignore the President's residual executive power.) 
adopt such seemingly servile resolutions? Once again, our reading of the Executive Power Clause provides the answer. Notwithstanding its fonts of foreign relations authority, Congress lacked the general power to communicate with foreign nations. Accordingly, by virtue of the Executive Power Clause, the President enjoyed this residual and significant executive authority. Domestically, it was well understood that the "Constitution left the whole business [of communication] in his breast." 385

Most foreign countries understood the same. ${ }^{386}$ When foreign countries mistakenly thought otherwise, the President corrected them. If they persisted in error, he refused to acknowledge their messages and commissions. As with many foreign affairs lessons of the period, Genet was at the epicenter of this one. As mentioned earlier, France had erroneously addressed its consuls' commissions to Congress. Jefferson informed Genet that the commissions should be addressed to the President and not Congress, as had been done under the Articles. Genet responded with a letter challenging the President's foreign affairs authority. He argued that Congress was in charge of foreign affairs. Jefferson issued a quick reply, notable for its distinctly undiplomatic tone:

[The President] being the only channel of communication between this country and foreign nations, it is from him alone that foreign nations or their agents are to learn what is or has been the will of the nation; and whatever he communicates as such, they have a right, and are bound to consider as the expression of the nation, and no foreign agent can be allowed to question it, to interpose between him and any other branch of Government, under the pretext of either's transgressing their functions, nor to make himself the umpire and final judge between them. ${ }^{387}$

Accordingly, Jefferson-on Washington's orders-returned two French commissions improperly addressed to Congress and told Genet that Washington would not issue exequaturs when the underlying commissions were not properly addressed to Washington. If France wished to have her consuls received, their commissions had to bear the proper addressee. ${ }^{388}$

Because Genet believed that Congress was pro-French in sentiment, he would not heed Jefferson's constitutional lesson. In a subsequent letter, Genet claimed that Congress was the proper addressee of commissions. In

385. 5 ANNALS OF CONG. 32 (1796) (statement of Sen. Oliver Ellsworth).

386. See, e.g., Letter from Don Diego de Gardoqui to George Washington (July 24, 1789), in GEORGE WASHINGTON PAPERS, http://memory.loc.gov/mss/mgw/mgw2/028/0450025.jpg (informing Washington that Gardoqui would leave for Spain at an opportune moment and introducing Washington to Gardoqui's temporary replacement).

387. Letter from Thomas Jefferson to Edmond Charles Genet (Nov. 22, 1793), in 6 THE WRITINGS OF THOMAS JEFFERSON, supra note 207, at 451, 451 (1895).

388. Id. 
response, Jefferson explained the new system at greater length. Under the old regime, foreign commissions were sometimes addressed to the United States and sometimes to Congress, the latter "body being then the executive as well as legislative." 389 Under the new regime, however, foreign commissions were to be addressed to the President, the new executive. Although the President might issue exequaturs in cases where a nation made an innocent mistake, he would not overlook formalities after a nation had been informed of the new regime. Henceforth, commissions should be addressed to the United States or the President. Otherwise they would be refused. ${ }^{390}$ In delivering this reply to Genet, Jefferson was merely voicing Washington's insistence that the commissions be properly addressed. ${ }^{391}$

Just a month later, Genet attempted to communicate with Congress indirectly by asking Washington to distribute copies of Genet's diplomatic instructions to Congress. Genet hoped that by distributing the instructions, he would be able to counter criticisms of his tenure in America. That he would ask Washington to distribute the instructions suggested that he finally understood that all communications had to be channeled through Washington. However, Jefferson upbraided Genet for attempting to contact Congress at all, declaring that all of Genet's transactions must occur with the Executive of the United States. Any communications between the President and Congress were none of his business, and he could not interfere. The "President must be left to judge for himself what matters his duty or the public good may require him to propose to the deliberations of Congress." ${ }^{392}$ With that indelicate message, Jefferson unceremoniously returned Genet's instructions. ${ }^{393}$

Throughout these episodes (and others), Genet sought to exploit possible differences between Congress and the President. Given the Constitution's allocation of executive power, however, Genet's attempts to treat with Congress were nothing short of extraordinary. In contrast, Jefferson's lessons were entirely unremarkable. He stated the obvious when he confirmed that:

[The President] being the only channel of communication between this country and foreign nations, it is from him alone that foreign nations or their agents are to learn what is or has been the will of

389. Letter from Thomas Jefferson to Edmond Charles Genet (Dec. 9, 1793), in 6 THE WRITINGS OF THOMAS JEFFERSON, supra note 207, at 463, 464 (1895).

390. Id. at $463-65$.

391. Thomas Jefferson, Cabinet Decisions (Dec. 7, 1793), in 6 The Writings of Thomas JEFFERSON, supra note 207, at 462, 462-63 (1895).

392. Letter from Thomas Jefferson to Edmond Charles Genet (Dec. 31, 1793), in 6 THE WRITINGS OF THOMAS JEFFERSON, supra note 207, at 495, 495-96 (1895).

393. Washington and Jefferson took this stance purely as a matter of constitutional form. Genet's instructions were in print, so Congress was well aware of his formal instructions. 
the nation; and whatever he communicates as such, they have a right, and are bound to consider as the expression of the nation. ${ }^{394}$

Genet's pigheadedness left us a valuable lesson. Most emissaries realized that their official communications were to be channeled through the President. Absent a stubborn Genet, however, we would lack Jefferson's cogent explanation of the executive power over foreign intercourse.

As we have recounted, Washington believed that he had a constitutionally granted monopoly over discourse with foreign countries. He spoke for the nation and heard from other nations and, just as importantly, decided which governments and nations could maintain relations with the United States. Apparently, Jefferson and Congress agreed. Accordingly, we believe that the Washington Administration's practices confirm the soundness of then-Representative John Marshall's famous comment: "The President is the sole organ of the nation in its external relations, and its sole representative with foreign nations." 395

The power to act as the nation's sole representative in international discourse goes well beyond any penumbras that might emanate from the reception power or the power to make treaties. The latter powers do not authorize the President to speak on behalf of the United States in all circumstances, nor can they be read to require that all foreign communications be funneled through the executive branch. In short, the power to receive certain foreign ministers hardly ensures that the President enjoys a constitutional monopoly over the nation's discourse with the other nations of the world.

Again, our residual theory explains why so many acknowledged that the President is the sole organ of communication. Because Congress lacks authority to speak on behalf of the nation, the President enjoys these authorities by virtue of his residual executive power over foreign affairs.

As noted earlier, although scholars of all stripes agree that the President controls communications with foreign states, none has been able to supply any textually sound reason for such presidential dominance. Legislative primacists cite presidential control over communications almost as an embarrassing exception to congressional primacy. While the President must receive and transmit all communications, those "powers" equate to nothing more than the powers to forward foreign messages to Congress or to convey Congress's wishes to foreign governments. But since legislative primacists cannot explain the textual basis for the "narrow" power they admit rests with the President, they cannot explain why broader foreign affairs powers

394. Letter from Thomas Jefferson to Edmond Charles Genet (Nov. 22, 1793), in 6 THE WRITINGS OF THOMAS JEFFERSON, supra note 207, at 451, 451 (1895).

395. 10 ANNALS OF CONG. 613 (1800). 
might not also lie with the President. On the other hand, although most presidential primacists eagerly cite presidential dominance as a building block for presidential primacy, they lack a sound textual basis for their foundation, thus calling into question their entire edifice.

\section{The President's Power To Terminate Treaties}

As discussed, our theory of residual foreign affairs powers suggests that the President has the power to terminate treaties. This power was part of the traditional executive foreign affairs power and is not allocated elsewhere by the Constitution. ${ }^{396}$ The discussions of treaty termination during the Washington Administration confirm that the political leaders of the postratification era shared this view.

In early 1793, France declared war on England and the Netherlands, beginning the Washington Administration's most serious and sustained foreign policy challenge. ${ }^{397}$ Among other matters, the events required close attention to two treaties between the United States and France, dating from 1778. Several clauses of these treaties might be read to obligate the United States to enter the war on France's side, or at least to take actions likely to bring on conflict with England. In particular, Article XI of the Treaty of Alliance required the United States to guarantee the security of France's Caribbean possessions, whose security would no doubt be menaced by English warships. ${ }^{398}$

Once news of the war arrived in April 1793, Washington gathered his cabinet to discuss the U.S. response. As a threshold matter, the news had arrived after the end of the 1792-1793 congressional term, so Washington had to decide whether to call Congress back into session. Washington, while recognizing the great foreign affairs issues at stake, decided not to call Congress, but to deal with the matter on his own authority. In this, his entire cabinet agreed. ${ }^{399}$ As we describe more fully in the next Section,

396. See supra Section II.C. In contrast, nontextual theories of foreign affairs power have no consistent solution to the treaty termination power. See ADLER, supra note 78, at 105-13, $114 \mathrm{n} .1$ (arguing that the President plus the Senate has the power); HENKIN, supra note 5, at 211-14 (arguing that the President has the power); Raoul Berger, The President's Unilateral Termination of the Taiwan Treaty, 75 NW. U. L. REV. 577, 605 (1980) (arguing that Congress has the power).

397. See ELKINS \& MCKITRICK, supra note 280, at 339-40.

398. See id. at 340 (identifying Article XI of the Treaty of Alliance and Articles XVII and XXII of the Treaty of Amity as the troublesome provisions). For the text of the treaties, see Treaty of Amity and Commerce, Feb. 6, 1778, U.S.-Fr., reprinted in TREATIES AND OTHER INTERNATIONAL ACTS OF THE UNITED STATES OF AMERICA 3 (Hunter Miller ed., 1931); and Treaty of Alliance, Feb. 6, 1778, U.S.-Fr., reprinted in TREATIES AND OTHER INTERNATIONAL ACTS OF THE UNITED STATES OF AMERICA, supra, at 35.

399. See supra Subsection VII.B.1. Washington put to his cabinet a list of thirteen questions (likely framed by Hamilton) including whether to recall Congress, how to deal with the French treaties, and whether to issue a proclamation of neutrality. See ELKINS \& MCKrTRICK, supra note 280 , at 337 . 
Washington then decided (again on his own authority, with the agreement of the cabinet) that the United States should pursue a policy of neutrality with respect to the warring nations. ${ }^{400}$

Deciding in favor of neutrality directly raised the issue of the treaties, since they might be read not to allow it, so Washington asked the cabinet whether the treaties should be renounced, or at least suspended. ${ }^{401}$ Specifically, Washington asked "[w]ith a view to forming a general plan of conduct for the Executive" whether "the United States" should "renounce [the treaties with France] or hold them suspended." ${ }^{402}$ Washington had already decided not to reconvene Congress, so plainly he thought that if "the United States" was to "renounce" the treaties, the President could do it on his own authority, as part of the "general plan of conduct for the Executive." 403

The question found no ready consensus, and Hamilton and Jefferson submitted opposing written opinions. Hamilton wanted to declare the treaties "temporarily and provisionally suspended"-primarily on the ground that the treaties had been made with the monarchy and that the new government in France was too unstable to be regarded as an appropriate successor. ${ }^{404}$ Jefferson replied that international law saw treaties as between nations, not between governments, and thus even violent succession was not a ground for termination. ${ }^{405}$ As a practical matter, Jefferson arguedcorrectly, as it happened-that France would not ask the United States to perform the guarantee and that the other provisions of the treaties would not become material issues for U.S. neutrality. ${ }^{406}$ Washington followed Jefferson and made no public comment on the treaties. ${ }^{407}$

400. See infra Section VII.E.

401. Letter from George Washington to Alexander Hamilton (Apr. 18, 1793), in 4 THE WORKS OF ALEXANDER HAMILTON, supra note 113, at 366, 367.

402. Id at 366-67.

403. Id. The decision not to recall Congress, and to proclaim neutrality, was made at the cabinet meeting, since everyone present ultimately agreed on the course of action. Because his advisers could not agree on a course of action with respect to the treaties, that matter was not decided at the meeting, and Washington subsequently requested written opinions from Hamilton and Jefferson. Hence the request and responses relating to the treatics were plainly made on the understanding that Congress would not be meeting. See ELKINS \& MCKITRICK, supra note 280, at $336-41$.

404. Letter from Alexander Hamilton to George Washington (Apr. 1793), in 4 THE WORKS OF ALEXANDER HAMILTON, supra note 113 , at $369,370,374$. Hamilion specifically urged Washington to make this announcement upon receiving the French minister (which obviously would not have allowed time for consultation with Congress). Hamilton further suggested that, depending on how events developed, the United States should renounce the treaties permanently, and nothing in his discussions of this option indicates any need for legislative approval. See id. at 374-75.

405. Thomas Jefferson, Opinion on French Treaties (Apr. 28, 1793), in 6 THE WRITINGS OF THOMAS JEFFERSON, supra note 207, at 219, 219.31 (1895); see ELKINS \& MCKITRICK, supra note 280 , at $339-40$.

406. See ELKINS \& MCKITRICK, supra note 280, at 340.

407. See id. at $340-41$. 
Critically, everyone in this discussion assumed that Washington had the constitutional authority to terminate or suspend the treaties. Washington had already decided not to recall Congress into session, so in asking the cabinet whether the treaties should be terminated, he obviously was asking whether he should terminate the treaties. Similarly, when Hamilton argued that the United States should suspend the treaties, he plainly meant the President should suspend the treaties (since Hamilton opposed recalling Congress). Most importantly, Jefferson, who might have raised the constitutional question as a strategic matter if nothing else, did not contest the President's constitutional authority to terminate or suspend the treaties. ${ }^{408}$ Rather, he argued entirely within the framework Washington presented - that is, that the decision was the President's. ${ }^{409}$

The convergence as to presidential treaty termination power should not be overread. In particular, in these debates everyone assumed that any termination would be done in accordance with the international law of treaties. Hamilton, for example, was at pains to show that (in his view) the law of nations permitted terminating the treaties; Jefferson, in response, took vigorous issue with this view. ${ }^{40}$ No one argued that the President

408. In his subsequent letters to Madison on the matter, Jefferson did take the position that the President did not have the power to renounce the treaties to the extent that such an act would infringe upon Congress's war power. As discussed below, this was essentially Madison's position in the Helvidius columns and is not inconsistent with a generalized presidential power to terminate treaties. In his April 28 opinion, however, Jefferson argued that the factual preconditions under international law necessary to "our right of releasing ourselves" from the treaties did not exist, while assuming that the "right of releasing ourselves" would be properly exercised by the President. Thomas Jefferson, Opinion on French Treaties (Apr. 28, 1793), in 6 THE WRITINGS OF THOMAS JEFFERSON, supra note 207, at 219, 224 (1895).

409. The lessons of subsequent events relating to the French treaties are less easy to read. In 1798 , in the opening phases of the "quasi-war" between the United States and France, Congress, at President Adams's invitation, passed a statute declaring that "the United States are of right freed and exonerated from the stipulations of the treaties, and of the consular convention, heretofore concluded between the United States and France; and that the same shall not henceforth be regarded as legally obligatory on the Government or citizens of the United States." Act of July 7,1798 , ch. 6 , 1 Stat. 578. Adams, however, did not deliver notice of termination of the treaties to France, and France continued to insist the treaties were in force as late as 1800 . See Gray v. United States, 21 Ct. Cl. 340 (1886) (recounting the negotiations of 1800); ADLER, supra note 78, at 151-60. It is not clear what to make of all this. If Adams wanted the treaties terminated and the law of nations permitted termination, the events of the Washington Administration suggest that Adams could have done it himself (and if Adams wanted the treaties terminated, it is in any event unclear why he did not deliver notice after passage of the Act). On the other hand, Adams did not veto the Act, and apparently wanted the treaties terminated. See ALEXANDER DE CONDE, THE QUASI-WAR 102-03 (1966) (attributing the termination to the concern that U.S. activities in preparing for war might violate the treaties). Further, Congress did not identify a source of its power in passing the Act, nor did either Adams or Congress describe how the law of nations permitted termination. One possibility is that the law of nations did not permit termination under the circumstances, and Adams knew jt; thus the Act was only intended to have domestic consequences, in eliminating the treaties' status as domestic law. This is consistent with Adams's failure to notify France of termination, either on his own authority or after passage of the Act. However, there is no direct evidence that this is what anyone was thinking.

410. See Cabinet Paper from Alexander Hamilton to Gcorge Washington (Apr. 1793), in 4 THE WORKS OF ALEXANDER HAMILTON, supra note 113, at 369, 370-87. 
could terminate the treaties in violation of international law, and Jefferson seemed to assume that the President would not do so. Thus the postratification consensus extended only to treaty termination in accordance with the law of treaties. ${ }^{411}$ Whether, as a matter of domestic law, the President could terminate a treaty in violation of international law is a question the administration did not appear to contemplate.

Given that in the eighteenth century the executive power was widely thought to include the treaty power, it is not surprising that Washington, Hamilton, and Jefferson believed that the President could decide whether to terminate or suspend a treaty. After all, the House had no direct treaty role and the Senate's role was but a check on treaty-making. Because the Constitution did not qualify or burden the power to terminate or suspend treaties, that power was lodged with whomever wielded the executive power.

\section{E. The President's Power To Establish Foreign Policy}

This Section focuses on the formation of United States foreign policy during the Washington Administration. As discussed, by "foreign policy" we mean the ability to publicly pronounce the views and goals of the United States-as Washington himself called it, the "disposition" of the United States ${ }^{412}$-on international matters, even though that policy might contradict or go beyond existing laws. ${ }^{413}$ Our theory of residual executive power over foreign affairs would give this power to the President, since the determination of foreign policy is an aspect of the traditional executive power not allocated elsewhere by the Constitution. As this Section reveals, ${ }^{414}$ the events of the Washington Administration-particularly in response to the war between England and France in 1793-1794 - confirm this understanding of executive power. ${ }^{415}$

411. Presumably by analogy that consensus would embrace the President's power to terminate a treaty in accordance with its express terms. See Goldwater v. Carter, 444 U.S. 996 (1979) (raising this issue).

412. See George Washington, Fifth Annual Address to Congress (Dec. 3, 1793), in 33 THE WRITINGS OF GEORGE WASHINGTON, supra note 281, at 164 (describing his Neutrality Proclamation earlier in the year as a statement of the United States's "disposition for peace").

413. See supra note 56.

414. Previous Sections confirm this as well, given the many instances recounted where Washington unilaterally set and announced the policy of the United States.

415. The Neutrality Crisis provides an example of the distinction that we made earlier, namely, the difference between policymaking in foreign affairs and lawmaking in foreign affairs. As illustrated below, Washington and his advisers plainly believed that the President had the power to declare U.S. policy to remain neutral in the war between England and France, and we agree that this is a necessary implication of the President's executive power. A more difficult question is what steps the President could take to implement this policy, and in particular whether the President's statement of policy was legally binding on anyone (beyond, obviously, those working in the executive branch). As indicated earlier, we think the implications of the executive power theory of foreign affairs are that the President's policy statement, of itself, was not binding, 


\section{The Neutrality Proclamation as Evidence of the President's Power To Set Policy}

The outbreak of war between England and France in 1793 precipitated for the United States what became known as the Neutrality Crisis. ${ }^{416}$ The United States had to decide what attitude to adopt toward the belligerents: a strict neutrality that both in theory and in practice favored neither side, a "benevolent" neutrality that as a practical matter favored France while officially pursuing equal treatment, or open support of France. ${ }^{417}$

The ensuing events, although complex in detail, are relatively straightforward on a general level. Washington did not call a special session of Congress, but instead determined on his own authority that the United States should pursue a policy of strict neutrality between England and France. To this end, Washington, with the endorsement of all of his cabinet, ${ }^{418}$ issued what has come to be known as the "Neutrality Proclamation" (although the Proclamation itself avoided the word "neutrality"), 419 and thereby officially declared that the United States would "with sincerity and good faith adopt and pursue a conduct friendly and impartial toward the belligerent powers." ${ }^{420}$

Over the following months, Washington developed the Proclamation's practical consequences: (1) No fighting would be permitted in U.S. territory; (2) no privateers or repairing warships would be fitted out in U.S. territory; (3) no U.S. citizens would enlist to fight; and (4) no prizes would

and as illustrated below, we think Washington and his advisers shared this view. See infra Section VII.F.

416. There are numerous accounts of the Anglo-French War and its impact on U.S. foreign relations. The following is taken largely from AMMON, supra note 354, at 32-64; ELKINS \& MCKITRICK, supra note 280; CHARLES MARION THOMAS, AMERICAN NEUTRALITY IN 1793 (1931); and Charles S. Hyneman, The First American Neutrality: A Study of the American Understanding of Neutral Obligations During the Years 1792-1815, ILL. STID. SOC. SCI., Nov. 1934, at 11-53. For other accounts, see CURRIE, supra note 280, at 174-82; MCDONALD, supra note 280, 113-39; and SOFAER, supra note 280, at 103-16.

417. See ELKINS \& MCKITRICK, supra note 280 , at $336-38 \& 816$ n.100. Given the recent war with England, the friendship and assistance France had given the United States, and the republican nature of the new French government, no one seriously contemplated that the United States would help England.

418. Jefferson's notes reflect that it was "agreed by all that a Proclamation shall issue." THOMAS, supra note 416 , at 42 n.5 (intemal quotation marks omitted).

419. This was apparently out of deference to Jefferson, who, for reasons that remain obscure to historians, thought it important that the word not be used. ELKINS \& MCKITRICK, supra note 280, at 338-39.

420. THOMAS, supra note 416 , at 42 . The Proclamation itself is short, with four key parts. First, it declared the United States's "friendly and impartial" policy. The Proclamation then "exhort[s] and wam[s] citizens of the United States carefully to avoid all acts and proceedings" contrary to such a stance. Third, it declares that U.S. citizens violating the above direction will not receive "the protection of the United States" against punishment by foreign powers. Finally and most forcefully, it declared that the President has directed the appropriate officials "to cause prosecutions to be instituted" against violators. The full text of the Proclamation can be found in THOMAS, supra note 416 , at $42-43$. 
be sold in U.S. territory. ${ }^{421}$ Washington also refused France's request for advance payment of the U.S. debt to France and rejected any discussions of a further treaty. ${ }^{422}$ In short, the substance of the policy was that France should receive no U.S. assistance in its conflict with England. ${ }^{423}$

Washington's policy was not well received in all quarters, as there was a good bit of pro-French sentiment in the country. Some doubted the Proclamation's propriety on various grounds. ${ }^{424}$ Hamilton, who had urged strict neutrality in the cabinet meetings, defended it in the popular press using the since-famous pseudonym "Pacificus." ${ }^{425}$ Although Pacificus's defenses ranged widely, for present purposes, his evaluation of the Proclamation's constitutionality is the most important: Pacificus set out a theory of presidential power essentially equivalent to the one we advocate. Specifically, Hamilton argued that the executive power traditionally included foreign affairs power. The Constitution had given the President the "executive power" by Article II, Section 1, but had also given aspects of the traditional executive power, including war and treaties, to other branches. Because these latter grants were exceptions to the executive power, whatever was not encompassed by them remained with the President. Neither a declaration of war nor treaty-making was implicated by the President's actions, so they were "executive" (and thus presidential) under Article II, Section 1. ${ }^{426}$

Even stated in summary form, the events of 1793 reveal a unilateral presidential power to set foreign policy. Although the United States, in early 1793 , plainly needed to formulate some response to the European war, Washington rejected calling Congress into special session. In this he was supported by all of his cabinet (although Jefferson initially noted the objection discussed below), and when Congress ultimately met, it congratulated Washington on his actions without raising any constitutional concerns. Why did Washington, his cabinet, and Congress suppose that the President had this unilateral power to develop U.S. foreign policy? The power is not derivable from presidential powers over the military and foreign ambassadors (since neither were involved), nor did it rest upon any preexisting law. We think that they read the Constitution as we do and believed that the power arose from Washington's executive power.

421. See Hyneman, supra note 416, at 54-150 (discussing these consequences in detail).

422. AMMON, supra note 354 , at $60-61$.

423. Washington also determined that he would make no decision or comment with respect to the French treaties, in particular the provision of the 1778 Treaty that obligated the United States to guarantee France's Caribbean possessions against attack. See supra Section VII.D.

424. See ELKINS \& MCKITRICK, supra note 280, at 343 (discussing the letters of "Veritas" appearing in the National Gazette in June 1793, which questioned Washington's authority to declare neutrality).

425. HAMILTON, supra note 113.

426. Id. at $436-44$. 
First, as described above, in the years leading up to 1793 both Congress and the Washington Administration had treated "the executive Power" as encompassing unallocated foreign affairs powers ${ }^{427}$ Jefferson, for example, had argued that "the transaction of business with other nations" was an executive power ${ }^{428}$ Oliver Ellsworth, speaking in the Senate, said that foreign communication "is positively placed in the hands of the Executive." 429 Madison had concluded (according to Washington's notes) that control over diplomats is "Executive and vested in the President by the Constitution." ${ }^{430}$ This consensus on a foreign affairs component to the President's executive power, in the years from 1789 to 1793, had supported the President's essentially uncontested assertion of foreign affairs power far beyond the narrow grants of Article II, Sections 2 and 3. Locating the power to deal with the 1793 crisis within "the executive Power" fits comfortably with prior interpretations of the Clause.

Second, the leading contemporaneous defense of Washington's Proclamation, that of Hamilton as Pacificus, directly identified Article II, Section 1 as its constitutional basis. ${ }^{431}$ According to Pacificus, the power to issue the Proclamation fell within the ordinary meaning of "executive power," since the executive power was the "organ of intercourse between the United States and foreign powers." ${ }^{432}$ Hamilton acknowledged that certain aspects of the traditional executive power were lodged elsewhere or were shared-specifically, appointments, declaration of war, and treatymaking. ${ }^{433}$ These, he said, were "exceptions and qualifications" to the general grant in Article II, Section 1; "[w]ith these exceptions, the executive power of the United States is completely lodged in the President." ${ }^{434}$

427. See supra Sections VII.A-D (noting the early acceptance of the President's control over the State Department, ambassadors, communications with foreign powers, and the termination of treaties on the basis of the President's executive power); see also infra Subsection VII.E.4 (discussing the Nootka Sound incident).

428. Thomas Jefferson, Opinion on the Powers of the Senate (Apr. 24, 1790), in 5 THE WRITINGS OF THOMAS JEFFERSON, supra note 207, at 161 (1895).

429. 5 ANNALS OF CONG. 32 (1796).

430. 6 THE DIARIES OF GEORGE WASHINGTON, supra note 316 , at 68.

431. "The second article of the Constitution of the United States, section first, establishes this general proposition, that "the EXECUTIVE POWER shall be vested in a President of the United States of America."' HAMILTON, supra note 113, at 437.

432. Id.

433. Id. at 438-39.

434. Id. at 439. It is unclear whether Hamilton made this specific argument in the cabinet meetings that ultimatcly approved the Proclamation. Jefferson, writing of the cabinet debates afterward, said that Hamilton's arguments in the meeting followed those later used as Pacificus. See Letter from Thomas Jefferson to James Madison (June 29, 1793), in 6 THE WRITINGS OF THOMAS JEFFERSON, supra note 207, at 325, 327 (1895). Since the central argument of Pacificus was that the Proclamation came within the residual executive power over foreign affairs, it may be that this point was made by Hamilton and accepted by Washington at the meeting. See THOMAS, supra note 416, at 38 (concluding on this basis that Hamilton made the executive power argument to the cabinet). However, it may not have been that specific argument Jefferson had in mind. 
Hamilton's view is especially persuasive because it explains a wide range of practices in the Washington Administration-not only the Proclamation, but also Washington's assumption of control over communications with foreign nations, Congress's complete cession of power over the State Department and ambassadors to the President, and the President's other substantive foreign affairs activities, including removal of ambassadors, recognition, and requests for recall of foreign ambassadors. ${ }^{435}$ (It also reveals the basis of Washington's deference to Congress in areas of Congress's enumerated power, particularly war and foreign commerce. ${ }^{436}$ ) And apparently it was widely accepted at the time, not only because Hamilton was able to persuade Washington and the cabinet of the propriety of the Proclamation, but also because it seemed implicit in other people's thinking about foreign affairs. ${ }^{437}$

Third, the only alternative explanation is that Washington simply seized powers not granted to him by the Constitution. ${ }^{438}$ This seems unlikely given Washington's statements in other contexts of the need to provide careful constitutional precedent and his attention to constitutional limits in other matters. ${ }^{439}$ Executive usurpation seems especially unlikely since, with exceptions noted below, no one seemed to have serious doubts that Washington had the power to establish a policy of neutrality. ${ }^{440}$ In particular, no one raised any objections in Congress. When Congress returned to session, it applauded Washington's Proclamation without constitutional reservation. ${ }^{441}$

Given this record, one may wonder why the events of 1793 have not been thought probative of the President's residual foreign affairs power.

435. See supra Sections VII.A, VII.C.

436. See infra Section VII.G.

437. For example, as discussed above, Jefferson had asserted, on the basis of the Vesting Clause alone, that the transaction of business with foreign nations was "executive altogether" and therefore an exclusive power of the President. Thomas Jefferson, Opinion on the Powers of the Senate (Apr. 24, 1790), in 5 THE WRITTNGS OF THOMAS JEFFERSON, supra note 207, at 161, 161 (1895); see supra Section VII.A.

438. See $\mathrm{KOH}$, supra note 3 , at 79-80 (suggesting this alternative).

439. See CURRIE, supra note 280, at 116-17, 297-98; MCDONALD, supra note 280 . Currie says that Washington had "an unconditional commitment to the Constitution." CURRIE, supra note 280 , at 297.

440. See infra Subsection VII.E.3 (explaining that the leading opponents of Washington's action did not quarrel with the President's residual foreign affairs power, but claimed that a declaration of neutrality fell within Congress's war power).

441. The Senate's resolution in response to Washington's 1793 annual message to Congress declared: " $[W] c$... contemplate with pleasure the Proclamation by you issued, and give it our hearty approbation. We deem it a measure well-timed and wise, manifesting a watchful solicitude for the welfare of the nation, and calculated to promote it." 4 ANNALS OF CONG. 18 (1793). Similarly, the House responded that it "witness[ed], with approbation and pleasure, the vigilance with which you have guarded against an interruption of th[e] blessing [of peace] by your Proclamation." Id. at 138. Even modern writers skeptical of the scope of the President's foreign affairs power acknowledge that "there is no doubt that the Congress favorably viewed Washington's actions." Stein, supra note 3 , at 481. 
First, the extent to which the United States faced a critical policy choice may not be fully appreciated. This view, by greatly oversimplifying the choices Washington faced and the amount of discretion he exercised in making them, causes the decisions of 1793 to seem less substantive than they in fact were. Second, although Washington's power was never subject to doubts sufficient to provoke a constitutional crisis, important voices were raised in opposition to the constitutionality of at least parts of his program. In particular, Madison, then a member of Congress, wrote the "Helvidius" essays in response to Hamilton's Pacificus, ${ }^{442}$ and in the cabinet, Jefferson temporarily opposed portions of the program, in part on constitutional grounds. ${ }^{43}$ This may have suggested to later generations that the leading Framers were hopelessly divided on the issue, and thus that "original" materials and interpretations cannot give much aid in resolving these questions. ${ }^{444}$ In the following discussion, we conclude that neither of these objections is persuasive.

\section{The Scope of Washington's Neutrality Decision}

Given its military weakness, there was little realistic prospect of the United States taking part in the actual fighting of the war. The French were well aware of this and never sought U.S. entry into the war, even if they thought the Treaty of Alliance might in theory oblige America. ${ }^{445}$ The French did expect that the United States would render substantial nonmilitary assistance (and deny the same assistance to England). Specifically, the French sought to use U.S. territory as a base for fitting out and commissioning privateers, repairing ships, condemning prizes, and enlisting soldiers and sailors to fight the enemies of France. ${ }^{446}$ The question was whether the United States would permit it.

Neither law nor policy dictated an obvious answer. Nothing in existing U.S. treaties or laws, or in the law of nations or international practice, required neutrality as the Proclamation defined it. Although international law theorists had written somewhat inconclusively on the obligations of neutrals, and U.S. diplomats later claimed that the law of nations required neutrality, in fact, there was ample precedent for what France desired.

442. JAMES MADISON, LeTters OF HeLvidIUS No. 1 (1793), reprinted in 1 LETTERS AND OTHER WRITINGS OF JAMES MADISON, supra note 295, at 611 .

443. ELKINS \& MCKITRICK, supra note 280, at 337-38.

444. See, e.g., Youngstown Sheet \& Tube Co. v. Sawyer, 343 U.S. 579, 634 (1952) (Jackson, J., concurring).

445. Genet's instructions explicitly acknowledged this point, and Genet so stated publicly soon after arriving in the United States. AMMON, supra note 354, at 21, 55; ELKINS \& MCKITRICK, supra note 280 , at 342.

446. ELKINS \& MCKITRICK, supra note 280, at 341-54. 
European nations frequently followed a policy of "benevolent neutrality" that favored one side in a conflict without engaging in actual hostilities. ${ }^{447}$

As a strategic matter, aiding France risked war with England, but many Americans sympathized with France, and in any event refusing assistance to France might cause France to take what it wanted by force. ${ }^{488}$ Before Washington announced his policy, local decisionmakers had adopted policies approaching benevolent neutrality. Governor Moultrie of South Carolina, for example, received Genet when the latter landed at Charleston and encouraged the French fitting out of privateers and preliminary organization of an expedition against Spanish Florida. ${ }^{449}$ Various French sympathizers urged this course at the national level, and the United States might well have proceeded along the path suggested by Moultrie-favoring France without actually entering the war-and hoped that England would not engage the United States in hostilities ${ }^{450}$ Even after the Proclamation, the United States might have gone some way in this direction, given the

447. As to international law, Elkins and McKitrick observe that:

Though many authorities on international law . . . had asserted that nations not involved in war ought to observe a strict impartiality in their relations with the belligerents ... there was little in the international practice of the eighteenth century to indicate general acceptance of such an assumption. It was not regarded as incompatible with neutral status that a nation might give very material assistance to one or more of the belligerents.

Id. at 816 n. 100 ; see also Hyneman, supra note 416, at 14-19 (making the same point). Vattel, writing in the eighteenth century, observed that nonbelligerent nations often "furnish[ed] a determined succour, allow[ed] some troops to be raised, or advance[d] money" to one side without provoking retaliation and commented that "this prudent caution in not always coming to an open break with those who give such help to an enemy ... has gradually given rise to the custom of not regarding such assistance . . . as an act of hostility." VATTEL, supra note 167, at 265. Of course it was understood that nonneutral conduct might provoke the disfavored side into military retaliation, but this was a calculated risk. See id. (noting that assistance rendered to an enemy, although often overlooked for strategic reasons, would be a ground for war).

448. Professor Sofaer writes of the episode:

The first question [submitted by Washington to the cabinet] involved the President's power to decide and enforce... the nation's policy toward belligerents. The entire Cabinet wished to avoid involvement in the European war. ... [But] neutrality was a policy replete with danger, even if it was the least dangerous course available. The existing treaties with France, and the pro-French feeling within the United States, made neutrality a policy that risked conflict with France. Yet to take any but a firmly neutral position would risk trouble with England.

SOFAER, supra note 280 , at 104.

449. AMMON, supra note 354 , at 45 . This was in early April, several weeks prior to the Neutrality Proclamation.

450. Historians debate whether Secretary of State Jefferson favored this view. Ammon argues that Jefferson "anticipated a neutral stance which would permit France all benefits possible while denying them to the British. He wished a benevolent neutrality of the kind then practiced by the European powers." $I d$. at 51 . Elkins and McKitrick dispute this reading, but agree that Jefferson's "friends and followers" overestimated "how far the United States might go, without paying any price for it, in abetting the French in their struggle against England." ELKINS \& MCKITRICK, supra note 280, at 338; see also Hyneman, supra note 416 , at 158 ("That Jefferson wished a benevolent neutrality in favor of France can hardly be denied."). 
Proclamation's lack of specificity ${ }^{451}$ The core of Washington's policy, however, was not just the Proclamation itself, but the strict interpretation of its requirements; for example, the President specifically declared (contra Moultrie) that French privateers were not to be fitted out, and asked governors such as Moultrie to end their cooperation in such endeavors.

In short, the decision on what (if any) assistance to give France was a serious policy question with enormous implications, and one that might have been decided differently. In deciding this question, Washington and his cabinet believed that the President had the authority to act unilaterally, and they consciously decided that involving Congress was unnecessary. Although U.S. diplomats later claimed that the decision was required by the law of nations, in fact it was, in April 1793, an open question, and a less risk-averse or more pro-French executive (such as Moultrie, or perhaps James Monroe ${ }^{452}$ ) might well have been more willing to risk English displeasure. Obviously the point here is not the correctness of the decision, but its importance-and the fact that (with the qualifications to be discussed below) the President's unilateral approach to the matter was not widely regarded as inappropriate.

\section{Dissenting Views}

As noted, the most prominent public defense of Washington's actions, by Hamilton as Pacificus, relied squarely on the Executive Power Clause. Curiously, Hamilton's argument has been marginalized. In particular, the importance of Pacificus's textual interpretation is commonly denied or greatly minimized. ${ }^{453}$ This may have arisen because Hamilton drew an energetic response from Madison as "Helvidius" and because Jefferson had some reservations about the Proclamation. That has suggested to subsequent generations that the Framers' inconsistent views cannot be

451. At a minimum, it seems that Jefferson was hoping for enough flexibility in implementation to allow France some benefits. See AMMON, supra note 354, at 51; Letter from Thomas Jefferson to James Madison (May 12, 1793), in 6 THE WORKS OF THOMAS JEFFERSON, supra note 200 , at 323, 323-25.

452. See ELKINS \& MCKITRICK, supra note 280, at 498-503 (discussing Monroe's partisan attachment to the French Revolution, ultimately leading to his recall as ambassador in 1796). At least one leading historian of the period appears to be of the opinion that Jefferson, had he been President, would have pursued a similar course. See AMMON, supra note 354, at 51.

453. Gerhard Casper, for example, asserts that no one during the Washington Administration claimed that the President exercised Locke's "federative power." CASPER, supra note 3, at 68 . In our view this is exactly what Hamilton was asscrting. Professor Powell notes (in a footnote) that Hamilton relied on the text, specifically the Executive Vesting Clause, to support his argument, but emphasizes that Hamilton also used structural and policy arguments. See Powell, supra note 3, at $547 \mathrm{n} .93$. While true, this formulation misstates the extent to which Hamilton relied on the Vesting Clause in support of his constitutional arguments. See CURRIE, supra note 280, at 177 ("To this day the crucial controversy over Hamilton's interpretation of the vesting clause has never been authoritatively resolved."). 
much of a guide to the proper interpretation. We strongly disagree, on two counts.

First, although it is true that Madison, and to some extent Jefferson, disputed parts of Hamilton's assertions, the scope of the disagreement was much narrower than is often supposed. As set forth below, much of the debate turned on the (fairly academic) question of whether the President could by his declaration bind Congress's subsequent ability to decide to enter the war. ${ }^{454}$ This core aspect of the debate did not contest the essential proposition that the Vesting Clause gave the President all the foreign affairs power not given elsewhere; rather it was a narrow debate about the extent of the war power. Second, to the extent Madison disputed the theory of residual executive powers, his thinking is too unsystematic to provide a dependable refutation.

Jefferson never rejected the idea of residual executive power over foreign affairs. Indeed, he could hardly do so, given his earlier claim that the transaction of business with foreign nations was executive in nature. Instead, he questioned the extent of the power, where it might be thought to bump up against congressional war power. In particular, Jefferson argued that a declaration of neutrality amounted to a declaration against war, and only Congress could decide that question. ${ }^{455}$ In any event, Jefferson's view did not persuade the cabinet, not even Attorney General Randolph, who was not a natural ally of Hamilton, and Jefferson eventually abandoned it. ${ }^{456}$ Although Jefferson later urged Madison to attack the Pacificus article, he did not seem to have the unconstitutionality of the Proclamation as his central focus, for he wrote to Madison, somewhat ambiguously: "Upon the whole, my objections to the competence of the Executive to declare neutrality ... were supposed to be got over by avoiding the use of that term. The declaration of the disposition of the U.S. hardly can be called illegal, tho, it was certainly officious and improper." ${ }^{457}$

Madison is a more complicated case. Many have noted that Helvidius is ultimately unpersuasive without fully explaining why. One obvious reason is that it was unpersuasive at the time: As Professor Sofaer notes, "[t]he

454. This was academic in two respects: First, Washington manifestly did not purport to bind Congress - although Hamilton may be read to say otherwise-and second, there was no prospect that Congress would declare war, for the practical reasons mentioned above.

455. As discussed, the view that a grant of a power to Congress implied a denial of that power to the President was a common assumption, shared by Hamilton and others. Hamilton and Jefferson disagreed only on the scope of Congress's war power, not upon larger structural principles. See HAMILTON, supra note 113, at 443 ("The Legislature alone can interrupt [the blessings of peace] by placing the nation in a statc of war.").

456. There is also doubt as to how firmly Jefferson himself believed his argument, since he also initially opposed the Proclamation in the cabinet debates on the ground that neutrality should be used as a bargaining chip. ELKINS \& MCKITRICK, supra note 280, at 337.

457. Letter from Thomas Jefferson to James Madison (June 29, 1793), in 7 THE WORKS OF THOMAS JEFFERSON, supra note 200, at 418, 421. Jefferson primarily objected to the supposed dishonor of the treaty with France. 
theory advocated by Madison in 1793 as to appropriate roles of the President and Congress had been rejected in practice even before his Helvidius papers saw the light of day." ${ }^{458}$ Ultimately Congress, when it reconvened, praised the President for his actions ${ }^{459}$ and passed a Neutrality Act in conformity with the Proclamation and its later elaboration. ${ }^{460} \mathrm{We}$ think, however, that there is a stronger reason: Madison's views, at least to the extent that he rejected the executive power theory, are essentially incoherent.

Madison as Helvidius did not argue directly against residual executive power over foreign affairs, and it takes some study to trace how that topic entered his discussion. Hamilton's Pacificus had overreached in at least one respect, in claiming that the Proclamation was intended to "make known to the Powers at war ... that [the United States] is ... under no obligations of treaty to become an associate in the war with either." ${ }^{461}$ This was, in fact, not what Washington intended: At Jefferson's urging, Washington had specifically deferred interpretation of the 1778 Treaty. ${ }^{462}$ But Hamilton's claim raised a constitutional question about the ability of Congress to later decide that the treaty required entry into the war. Madison seized upon this as Hamilton's most vulnerable point, and made it the centerpiece of his attack. As Madison summarized,

The substance of the first piece [of Pacificus] ... [is] ... That, in particular, the executive had authority to judge, whether, in the case of the mutual guaranty between the United States and France, the former were bound by it to engage in the war: That the executive has, in pursuance of that authority, decided that the United States are not bound: and, That its proclamation of the 22d of April last is to be taken as the effect and expression of that decision. ${ }^{463}$

In response, Madison adopted Jefferson's argument that such an interpretation of the treaty was part of the war power, and thus a power of Congress. Here he did not quarrel with Hamilton in theory, for Hamilton agreed that the war power lay exclusively with Congress. The scope of the war power became the critical issue.

Hamilton had argued that because the war power was originally an executive power that had been given to Congress by the Constitution, the

458. SOFAER, supra note 280 , at 115 .

459. See 4 ANNALS OF CONG. 17-18, 138-39 (1793); CURRIE, supra note 280, at 182.

460. Neutrality Act, ch. 50, 1 Stat. 381 (1794).

461. HAMILTON, supra note 113, at 434.

462. ELKINS \& MCKITRICK, supra note 280, at 339-41. This likely was Jefferson's greatest objection to the Pacificus letters, since they specifically misstated a decision that had been taken, at Jefferson's urging, in the cabinet meeting. See Letter from Thomas Jefferson to James Madison (June 29, 1793), in 7 THE WORKS OF THOMAS JEFFERSON, supra note 200, at 418, 420-21.

463. MADISON, supra note 295, at 612. 
grant should be construed strictly. ${ }^{464}$ Madison objected, arguing that the war power (and treaty-making power) was not truly executive in substance but was only treated so, incorrectly, by the English Constitution and by political theorists. Thus, the U.S. Constitution put the war power where it belonged, in the legislature, and as a result the scope of the power should be construed broadly, not strictly. ${ }^{465}$

So far, Madison had not said anything inconsistent with the residual executive power theory. Madison and Hamilton agreed that war- and treatymaking were executive powers under the English Constitution and in the theories of Locke and Montesquieu, but that the Constitutional Convention thought that such an arrangement gave too much power to the executive and hence limited them or conveyed them elsewhere. That is wholly consistent with our theory. We are not immediately concerned with how broadly the war power should be construed, although we do not think-and we do not think Madison meant-that the war power could be construed to cover all foreign affairs powers. Madison was making the much narrower claim that to the extent there was a question whether the United States was bound to go to war, that was a question for Congress, which seems to us a plausible interpretation of the war power. ${ }^{466}$

In the heat of argument, however, Madison made what we regard as an indefensible claim. Madison wanted to show that the war power was not naturally an executive power, and thus the war power of Congress should be construed broadly instead of strictly. Among other arguments in this direction, Madison attempted a comprehensive definition of executive power: "The natural province of the executive magistrate is to execute laws, as that of the legislature is to make laws. All his acts, therefore, properly executive, must presuppose the existence of the laws to be executed." ${ }^{677}$ Taken at face value, this claim squarely rejects our theory of residual executive power, since it would read the Executive Power Clause as only conveying the power of law enforcement. ${ }^{468}$

But Madison's position is riddled with difficulties. First, Madison himself had, in less partisan moments, acknowledged that the President had

464. HAMILTON, supra note 113.

465. MA.DISON, supra note 295, at 613-21.

466. In fact, Washington did not claim to make a final decision in this regard (since Washington agreed with Jefferson to defer action on the meaning of the treaties), and it is not even clear that Pacificus claimed that power on his behalf (since Pacificus seemed to think that Congress had a concurrent power and so presumably could reverse the President's decision). See HAMILTON, supra note 113. Madison was thus essentially arguing against a straw man.

467. MADISON, supra note 295, at 614-15 (emphasis added).

468. Relatedly, later in the essays Madison argued (almost as an aside) that the President could not have refused to receive Genet, since this was not a power encompassed within the enumerated power to "receive" ambassadors, nor was it done in execution of a particular law. JAMES MADISON, LETTERS OF HELVIDIUS NO. 3 (1793), reprinted in 1 LETTERS AND OTHER WRITINGS OF JAMES MADISON, supra note 295 , at 630,630 . 
powers beyond law enforcement, including the power to control diplomatic officers. ${ }^{469}$ Further, essentially everyone at the time accepted the idea that the President had power over communication with foreign governments and control of the U.S. diplomatic corps. ${ }^{470}$ If Madison stuck to his claim that the President had only law enforcement power plus the specific grants of Article II, Sections 2 and 3, where did he think the President found communicative and diplomatic powers? And once he found a source for these powers, how would he be able to explain why that source did not also give the President policymaking authority? Madison did not grapple with these problems. Second, Madison failed to recognize that some of the foreign affairs powers he would deny the President would be difficult to locate in Congress. Madison said, for example, that refusal to receive an ambassador should be made by Congress and not the President. ${ }^{471}$ But pursuant to what congressional power? Madison suggested that the war power might serve this purpose since, he said implausibly, failure to receive an ambassador might lead to war. This is an extraordinary stretch, and even that argument would not work in all circumstances. In particular, if the power to communicate with foreign nations was not an executive power, presumably Congress must have held it. Yet Congress lacks such a specific enumerated power, and although the war power might stretch to cover some communications, surely it cannot stretch to cover all of them. Again, Madison did not address these problems.

We believe Madison had not carefully considered the implications of his claim. In context, that is not surprising. It was not the central point of the Helvidius essays, which concerned the power of the President to interpret treaty obligations relating to war. Madison never denied the power of the President to communicate, or even the power of the President to formulate substantive foreign policy not immediately connected to war. $\mathrm{He}$ was not thinking systematically about the whole of foreign affairs power, but was merely searching for an additional argument to deploy against Hamilton. His immediate point-that the President cannot bind congressional war power by an interpretation of a treaty - was distinct from his attack on the residual power over foreign affairs. His wider claim that the President exercises no power other than in pursuance of a law or an Article II, Section 2 or 3 power is demonstrably wrong in practice and incoherent in theory. We think it should be regarded as an overstatement in

469. In particular, in the course of the removal debates Madison said that the President had power to remove the Secretary of State, and in the course of the diplomatic funding debate he said that the President had the power to set the rank and destination of diplomatic officers. In both instances, Madison identified the executive power as the source of the powers in question. See supra Section VII.B (discussing Madison's opinion on diplomatic officers and his role in the removal debates).

470. See supra Sections VII.A-C.

471. MADISON, supra note 468, at 631-33. 
support of a cause, not as a systematic interpretation worked out after careful reflection. If posterity is to ignore or downplay Pacificus's claims, it should not do so based on the supposed strength of Helvidius's arguments. Helvidius was no match for Pacificus.

\section{Postscript on the Nootka Sound Incident}

The events surrounding the 1793 crisis were not unique in the Washington Administration. In 1789-1790, a similar, although less wellknown, series of events arose as a result of a near-war between Britain and Spain. In 1789, Spain seized a British post at Nootka Sound, in modern British Columbia. ${ }^{472}$ Britain seemed likely to retaliate by attacking Spanish colonies in North America. Washington asked his cabinet what U.S. policy should be. Specifically, he asked how the United States should respond if Britain requested permission to move troops across U.S. territory to attack Spanish New Orleans. ${ }^{473}$

The cabinet divided as to the proper response, both on the specific question whether British troops should be given permission to cross U.S. territory, and on the general question whether the United States should adhere to strict neutrality or favor one side. ${ }^{474}$ Ultimately, Washington did not announce a policy, because Britain and Spain resolved the matter through diplomacy, and British troops had no need to enter U.S. territory. But the incident showed one common thread in the thinking of a cabinet otherwise divided on the proper response: Everyone agreed that this was a matter the President could handle unilaterally. The only circumstance in which anyone envisioned calling Congress into session was if Britain moved troops into the United States without asking permission (or moved them after permission had been denied). In such a case, said Hamilton, "it would appear advisable immediately to convene the Legislature; ... and if satisfaction should be refused, to endeavor to punish the aggressor by the sword." 475

Most significantly, Jefferson advised a policy of neutrality as long as Britain did not seek territorial conquests and Spain permitted U.S. use of the Mississippi River, but he advised abandoning neutrality in favor of

472. See SOFAER, supra note 280 , at 101-03 (describing the events of the Nootka Sound incident).

473. Id. at 101-02.

474. Id at 102-03. Hamilton advised Washington to grant permission to cross. Jefferson suggested ignoring the request, but if a response were required, he also suggested granting permission. Id. at 102.

475. Letter from Alexander Hamilton to George Washington (Sept. 15, 1790), in 4 THE WORKS OF ALEXANDER HAMILTON, supra note 113, at 313, 342. Secretary of War Knox agreed that Congress should be convened only if the British marched without permission, since "Congress are vested with the right of providing for the common defence, and of declaring war." SOFAER, supra note 280, at 102 (quoting Knox). 
cooperation with the other side if one side did not agree to these conditions. On the question of the British troops, Jefferson agreed with Hamilton that passage should be permitted. As to each of these questions, Jefferson obviously thought Washington had the authority to determine them unilaterally ${ }^{476}$ Like the events of 1793 , the Nootka Sound incident shows a consensus that the President had power to handle foreign policy matters short of war, and that Congress needed to be involved only when a question of war arose. Again, that is wholly consistent with our theory of residual foreign affairs powers and very difficult to explain in any other manner.

\section{F. Presidential Lawmaking Power over Foreign Affairs}

Washington encountered only scattered opposition to his announcement of neutrality, but he had more difficulty enforcing it. Historians of the period comment in strong terms on the problems of enforcement, which were primarily due to the fact that the Proclamation had no statutory law behind it. ${ }^{47}$ Washington's enforcement efforts show that although he had some powers unilaterally to implement foreign policy, there was an important limit on executive power over foreign affairs as originally understood: It did not have the force of law. ${ }^{478}$

In attempting to enforce the Neutrality Proclamation, Washington relied principally on four methods. First, the administration apparently thought the Proclamation's goals could be achieved by diplomatic appeals to Genet and the French diplomatic agents acting at his direction: If Genet could be persuaded to stop arming privateers, refitting ships, and recruiting U.S. citizens to fight for France, many of the potential difficulties with England could be avoided. As a result, much of the "enforcement" activity of the Washington Administration involved diplomatic pressure on Genet, and Washington seemed genuinely shocked when Genet refused to comply with

476. See Thomas Jefferson, Opinion on Course of United States Towards Great Britain and Spain (Aug. 28, 1790), in 5 THE WRITINGS OF THOMAS JEFFERSON, supra note 207, at 238, 23839. These events confirm that Jefferson unambiguously endorsed residual executive power over foreign affairs when his thinking was not clouded-as it was in the Neutrality Crisis-by his attachment to France.

477. AMMON, supra note 354, at 70-71 (noting "the difficulty of enforcing neutrality without specific statutes imposing punishments"); MCDONALD, supra notc 280, at 128 (noting "the weakness of the administration's authority" with regard to enforcement); THOMAS, supra note 416 , at 170 (noting that Genet's argument "that there was no law of the United States which prevented citizens [from] enlisting ... gave the cabinet and many attorneys and judges more worry"); Hyneman, supra note 416 , at 83 (noting that "[t] ]he secretary of state did not explain where he was to find the law which would be relied on to punish the individuals infringing the rules laid down by the President and his cabinet"); id. at 151,155-57 (making the same point).

478. This is consistent with our view of foreign affairs powers deriving from executive power, as the traditional executive power did not include the ability to make laws in support of foreign affairs goals. See supra Part III. 
administration requests. ${ }^{479}$ Matters came to a head in June 1793, when Genet directed the refitting of a captured ship, the Little Sarah, in Philadelphia harbor. Despite a direct request from the administration that the Little Sarah not leave port, Genet permitted the ship (renamed the Petite Democrate) to sail as a privateer in July. ${ }^{480}$ By mid-summer 1793, the strategy of diplomatic pressure in ruins, Washington began the process of requesting Genet's recall, and directly threatened to revoke (and in at least one case actually did revoke) the authority of French consuls who did not abide by the President's neutrality directives. ${ }^{481}$ Washington and the cabinet plainly believed the President had the unilateral power to conduct this diplomatic campaign, but the stubbornness and ideological commitment of Genet prevented it from having its intended effect.

Second, Washington appealed to the state governors to suppress nonneutral activity in their states. ${ }^{482}$ In part, this arose from necessity: The federal government simply did not have the manpower to accomplish this directly. Moreover, as indicated, some state governors such as Moultrie followed a policy of benevolent neutrality, and-as with GenetWashington thought a presidential appeal would be sufficient. To some extent the appeal was successful: Moultrie and others changed their public position and issued their own proclamations against nonneutral activity, and some governors instituted affirmative actions to suppress that activity. ${ }^{483}$ For various reasons, however, state enforcement also proved insufficient. ${ }^{484}$

As state governors proved unable or unwilling to handle the matter, Washington moved to engage federal officers in preventative measures. Washington and his cabinet evidently believed that the executive could use force against foreign vessels violating executive directives. In connection with the Little Sarah incident in July 1793, for example, the cabinet (in

479. On several occasions, Genet promised to stop his consuls from condemning prizes, but he never issued the appropriate instructions. Ultimately Jefferson, in a letter to the consuls, threatened to revoke their papers if further condemnations occurred. On these matters, see AMMON, supra note 354, at 65-93; and ElKINS \& MCKITRICK, supra note 280, at 341-54. See also Hyneman, supra note 416, at 85-86 (noting the administration's unsuccessful diplomatic pressure on Genet); id. at 95,119 (discussing Jefferson's instructions to consuls).

480. On the Little Sarah incident, see AMMON, supra note 354, at 86-93; and THOMAS, supra note 416, at 137-44. For a legal perspective, see Powell, supra note 8, at 1490-95.

481. See Hyneman, supra note 416, at 118-21; supra Subsection VII.B.2.

482. Hyneman, supra note 416 , at 77 . Washington requested that if assistance to France was occurring "you will effectively put a stop to it" without specifying how or under what source of authority. Id. (internal quotation marks omitted). His letters did not assert that the Proclamation placed the governors (or their citizens) under any legal duty to stop such activity. See id. On various governors' responses, see $i d$. at 156-57.

483. Governor Clinton of New York seized a French privateer by force, leading to protests by Genet. See Powell, supra note 8, at 1488. Governor Mifflin of Pennsylvania considered using force to stop the Little Sarah from leaving Philadelphia as a French privateer and consulted with Washington's cabinet on the matter; in the absence of unambiguous cabinet support, Mifflin did nothing to stop the ship. Id. at 1490-92.

484. In particular, state governors "were not furnished with armed vessels or with artillery sufficient to make their orders effective," Hyneman, supra note 416, at 157. 
Washington's absence) considered using military force to stop the refitted privateer from leaving port. Concerned over provoking war with France, the cabinet was unable to reach a decision before the Little Sarah sailed, but all the cabinet members who considered the matter appeared to believe that the executive branch did have the constitutional authority to use force against the French vessel ${ }^{485}$ Following the Little Sarah debacle, Washington moved to involve the federal collectors of customs, the principal federal officers in the port cities, in efforts to prevent refitting privateers and related activities by force. In August, Washington, with the advice of his cabinet, issued a set of directives, styled "deductions from the laws of neutrality," embodying his neutrality policy, and he transmitted them to the state governors and to the federal collectors of customs. ${ }^{486}$ The intent was that the collectors, who had broad discretion in admitting and clearing ships, would be able to detain or refuse entry to ships violating Washington's policies. ${ }^{487}$

Fourth, and crucial for our discussion, Washington's administration directed prosecutions against U.S. citizens violating neutrality. ${ }^{488}$ The bestknown involved Gideon Henfield, who enlisted on a French privateer (an act proscribed by the Proclamation) ${ }^{489}$ But unlike the activities described above, the Henfield prosecution and others like it were from the beginning plagued with doubts as to the President's constitutional authority; ultimately, the prosecutions proved unsuccessful until 1794, when Congress by statute criminalized nonneutral behavior. This sequence confirms our view that executive foreign policy, standing alone, lacked the force of law.

485. Complicating the cabinet's deliberation was the fact that Washington was unreachable on vacation as the Little Sarah prepared to sail. See Powell, supra note 8, at 1490 . On the cabinet's view of his authority, see id. at 1491-92. In Powell's view, "Washington and his advisors clearly believed that the President's authority with respect to foreign affairs carried with it some power to take military action without congressional sanction in order to achieve the executive's goals." Id. at 1495.

486. Hyneman, supra note 416 , at 77-78. Washington first asked the Supreme Court for advice in formulating his neutrality rules, famously leading to the Court's refusal to give advisory opinions. See David P. CuRrie, The ConstituTION IN THE SuPREME CoURT 11-14 (1985). Washington's phrase "the laws of neutrality" was presumably a reference to the law of nations, as Congress had not yet acted in the area. As discussed below, and as also illustrated by the instructions to the customs officials, Washington apparently did not consider the Proclamation itself to have legal effect and thus sought to ground his instructions in a more authoritative legal source - in this instance, the law of nations. See infra notes 490-501 and accompanying text.

487. Hyneman, supra note 416 , at $77-78$.

488. There is doubt as to how many. The only one for which complete records exist is that of Henfield, discussed below. Hyneman argues that a number of others were brought, but his evidence is largely circumstantial. Hyncman, supra note 416 , at $83-84 \&$ n.44. Professor Sofaer says that the acquittal of Henfield, discussed below, caused the government to drop other prosecutions, but this also does not seem fully substantiated. SOFAER, supra note 280, at 110 .

489. Henfield's Case, 11 F. Cas. 1099 (C.C.D. Pa. 1793) (No. 6360); see also STATE TRIALS OF THE UNITED STATES DURING THE ADMINISTRATIONS OF WASHINGTON AND ADAMS 49 (Burt Franklin 1970) (Francis Wharton ed., 1849) (reporting the "[t]rial of Gideon Henfield, for Illegally Enlisting in a French Privateer, in the Circuit Court of the United States for the Pennsylvania District, Philadelphia, 1793"). 
Most importantly, although the legal authority for the prosecutions was contested, no one in the Washington Administration or the courts pointed to the Proclamation as a possible source of legal authority. The Proclamation itself did not appear to claim legal force of its own; rather, Washington said that he would "cause prosecutions to be instituted against all persons who shall, within the cognizance of the courts of the United States, violate the law of nations." ${ }^{490}$ Jefferson's official communication to the U.S. Attorney in Philadelphia directing prosecutions made no mention of the Proclamation, stating only that "certain citizens of the United States, have engaged in committing depredations on the property and commerce of some of the nations at peace with the United States" and directing the attorney to "take such measures for apprehending and prosecuting them as shall be according to law." ${ }^{491}$ Washington was sufficiently worried, though, that he requested an opinion from Attorney General Edmund Randolph. Like Jefferson, Randolph did not say the Proclamation was law, but relied instead on treaties and the common law of disturbing the peace. ${ }^{42}$

The court proceedings against Henfield took a similar course. Prosecutors adduced treaties, the law of nations and common law-but not the Proclamation - as the source of the law that Henfield violated. ${ }^{493}$ In its charge to the jury, the court did not rely upon the Proclamation as a source of law. Instead, it cited the law of nations, as part of the common law, ${ }^{494}$

490. THOMAS, supra note 416 , at 43.

491. Letter from Thomas Jefferson to W. Rawle (May 15, 1793), quoted in STATE TRIALs OF THE UNITED STATES DURING THE ADMINISTRATIONS OF WASHINGTON AND ADAMS, supra note 489, at 51. As Hyneman observes, "[i]t is hardly likely that the secretary of state was of the opinion that the President's order was in itself sufficient to make illegal the activities complained of; one is all but positive that Randolph, the attorney general, would have vigorously combatted any such doctrine." Hyneman, supra note 416, at 83 . This is confirmed by Jefferson's long private letter to James Monroe in which he discusses various legal bases for the prosecutions without even mentioning the Proclamation. See Letter from Thomas Jefferson to James Monroe (July 14, 1793), in 6 THE WRITINGS OF THOMAS JEFFERSON, supra note 207, at 346, 347-48 (1895). Jefferson here expresses more doubt than he did publicly as to the prosecutions' legal basis. See id.

492. Edmund Randolph, Opinion of the Attorney General to the Secretary of State (May 30, 1793), in 1 AMERICAN STATE PAPERS, FOREIGN RELATIONS, supra note 357, at 152. Randolph found the offense punishable " because . . . by treaties with three of the Powers at war with France, it is stipulated, that there shall be a peace between their subjects and the citizens of the United States ... [and] because ... [Henfield's] conduct comes within the description of disturbing the peace of the United States." Id. He did not mention the Proclamation. See THOMAS, supra note 416 , at 170 .

493. State TRlals OF the United States DuRING THE ADMinistrations OF WASHINGTON AND ADAMS, supra note 489 , at 78-83.

494. The existence of a federal common law of crimes was, of course, greatly debated during this period, so the Washington Administration was hardly on safe legal ground in offering common law as its legal authority. Indeed, in later cases that basis was authoritatively rejected by the Supreme Court. See United States v. Hudson \& Goodwin, 11 U.S. (7 Cranch) 32, 32 (1812) (holding that "the Circuit Courts of the United States can[not] exercise a common law jurisdiction in criminal cases"); see also United States v. Coolidge, 14 U.S. (1 Wheat.) 415, 416 (1816) (refusing to "review ... or draw into doubt" Hudson \& Goodwin because "the attomey general has declined to argue the cause; and no counsel appears for the defendant"). We take no position 
and U.S. treaties, made the supreme law of the land through Article VI of the Constitution. ${ }^{495}$ But opponents of the prosecution argued that it essentially rested on the Proclamation alone and opposed it on that ground. Articles in the popular press, for example, said that the prosecution "was trying to give a proclamation the force of a law" ${ }^{496}$ and asked rhetorically, "Were the American people already prepared to give to a proclamation the force of a legislative act, and to subject themselves to the will of the Executive?" 497

Despite overwhelming evidence of Henfield's "guilt," the jury refused to convict. The jury's problem, historians generally agree, was that although Henfield had violated the Proclamation, there was no law making his conduct criminal. ${ }^{498}$ The opposition papers chided Washington for "having attempted a measure which the laws would not justify." 499 The

here on the dehate over common-law crimes; as we regard it as largely beside the present point. What is critical, however, is that no one suggested the Proclamation as an alternative basis.

495. Judge Wilson, speaking for himself and Judges Iredell and Peters, said:

It has been asked by [Henfield's] counsel . . . against what law has he offended? The answer is ... he was bound to keep the peace in regard to all nations with whom we are at peace. This is the law of nations. ... There are, also, positive laws, existing previous to the offense committed, and expressly declared to be part of the supreme law of the land.

State Trials of the United States DuRing the administrations of Washington and ADAMS, supra note 489 , at 84 . Wilson then described U.S. treaties with Britain and the Netherlands which, he said, were violated by Henfield's actions. Id. at 84-85. Wilson's charge to the grand jury that indicted Henfield is to the same effect, without reliance on the Proclamation. Id. at 59-66. An earlier grand jury charge on the same subject, by John Jay, did mention the Proclamation. See id. at 49,53. Jay did not rely on the legal force of the Proclamation, however; he instead cited it as declaratory of the law of nations, and rested the prosecution upon a violation of the law of nations. Id. at 54 ("The proclamation is exactly consistent with and declaratory of the conduct enjoined by the law of nations."). As discussed, see supra note 447 , Jay surely overstated the requirements of the law of nations here. The key point is that Jay felt the need to overstate to align the Proclamation with the law of nations, rather than base the prosecution on the Proclamation alone.

496. THOMAS, supra note 416 , at $172 \mathrm{n.8}$ (referring to an undated article in the National Gazette); see also id. at 172 \& $\mathbf{n} .2$ (citing a letter from Jefferson to Monroe on the discord in the legal community over the validity of the prosecution).

497. STATE TRIALS OF THE UNITED STATES DURING THE ADMINISTRATIONS OF

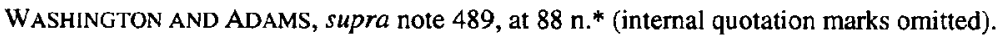

498. AMMON, supra note 354 , at 71 (observing that "the absence of a statutory prohibition gave the jury (frankly sympathetic to Henfield) convenient grounds for acquittal"); THOMAS, supra note 416, at 173 (attributing the result perhaps to "the popular dislike of anything that resembled convicting a man of a crime established only by an executive proclamation"); see also Jules Lobel, The Rise and Decline of the Neutrality Act: Sovereignty and Congressional War Powers in United States Foreign Policy, 24 HARV. INT'L L.J. 1, 14 (1983) ("Henfield was nevertheless acquitted, in all probability because of the popular sentiment in favor of France and a feeling among jurors that violation of a presidential proclamation should not constitute a criminal offense.").

499. STATE TRIals OF THE United STates During the administrations of WASHINGTON AND ADAMS, supra note 489 , at $89 \mathrm{n} . *$ (internal quotation marks omitted). Professor Thomas says the verdict "increased the suspicion that in trying to prevent enlistments, the government was attempting a measure not justified by the laws. This increased the censure that was being directed against the government and also decreased the effectiveness of measures intended to prevent future enlistments." THOMAS, supra note 416, at 175. 
failure of what the administration saw as a test case caused great concern in the cabinet, which considered calling Congress into special session to pass neutrality laws. ${ }^{500}$ Washington rejected this expedient, but once Congress reconvened he requested an act "to extend the legal code and the jurisdiction of the Courts of the United States to many cases which, although dependent on principles already recognized, demand some further provisions." 501 In response, Congress passed what has become known as the Neutrality Act, endorsing the positions the administration had taken. ${ }^{502}$

As a result, it seems clear that few people thought the President could, as a general matter, create legal obligations through his constitutional foreign affairs powers. Despite the prominence of the Proclamation, in enforcing neutrality Washington and his subordinates always claimed to be enforcing something else-common law, treaty law, or the law of nationsand not the Proclamation itself. These claims were not very convincing, and the objection laid against the prosecutions was that no law forbade the activities in question. Washington, it was said, was trying to give the Proclamation the force of law, a position thought self-evidently indefensible.

The reasons for the nonlegal status of the Proclamation were not widely discussed, for the administration did not claim to have such a power and its critics thought it obviously did not. The common view is, however, quite consistent with the textual derivation of foreign affairs power we propose. If the President's foreign affairs power is "inherent" or derivative of some extraconstitutional principle, it is not obvious that that power encompasses only policy and not lawmaking. ${ }^{503}$ If, however, the Founding generation saw it as derived from the residual textual grant of "the executive Power," as we believe, the assumed limitation is understandable: The traditional executive power over foreign affairs did not include a general power of legislation in support of foreign affairs objectives.

In sum, then, the Neutrality Proclamation and its aftermath showed an understanding of executive power in which the President could determine and announce U.S. foreign policy and could use diplomatic pressure and

500. See id. at $175 \&$ n.3. Jefferson thought Congress should be summoned, among other reasons, because "several legislative provisions are wanting to enable the govemment to steer steadily through the difficulties daily produced by the war of Europe, and to prevent our being involved in it by the incidents and perplexities to which it is constantly giving birth." Thomas Jefferson, Opinion on Calling of Congress (Aug. 4, 1793), in 6 THE WRITINGS OF THOMAS JEFFERSON, supra note 207 , at 362,363 (1895).

501. 4 ANNALS OF CONG. 11 (1793) (statement of President Washington). Currie says that Washington "made neutrality his first order of business when the Third Congress met in December 1793." CURRIE, supra note 280, at 182.

502. Neutrality Act, ch. 50, 1 Stat. 381 (1794).

503. Indeed, modern formulations of presidential power over foreign affairs, which tend to be grounded in some notion of inherent power rather than text, often accept some degree of executive lawmaking authority. See HENKIN, supra note 5, at 54. 
even military force against foreign governments and their instrumentalities to enforce it. However, the executive power did not extend to the creation of obligations under domestic law, and thus the domestic legal system could not be invoked to enforce a unilateral presidential policy having no other basis in law.

\section{G. Congressional Foreign Affairs Powers}

In this Section, we focus on the exercise of foreign affairs powers by Congress during the Washington Administration. We find that the practice conforms to our theory of executive foreign affairs powers. As discussed, our theory denies Congress a general power over foreign affairs, but posits two broad sources of congressional authority over foreign affairs matters. First, Congress has powers specifically granted to it by the Constitution's text (plus the additional authority ancillary to these powers provided by the Necessary and Proper Clause). These powers are exercised independently of the President (subject, of course, to the veto). Second, Congress has derivative powers - that is, Congress can legislate to carry into execution presidential foreign affairs powers. These powers must be exercised in coordination with the President.

\section{Independent Powers of Congress}

In setting forth our theory of foreign affairs powers, it is important to stress not only the scope of the President's power, but also the limits upon it. In particular, as discussed below, our theory emphasizes that, for the most part, the President's power over foreign affairs is residual. In areas where Congress has a power or where the Senate shares a power, the President cannot exercise such powers unilaterally.

One characteristic of Washington as President was that he sometimes acted with great deference to Congress and the Senate in foreign affairs, and sometimes acted unilaterally. This allows the various camps of foreign affairs scholars to claim precedent for their view in the Washington Administration: Advocates of presidential primacy in foreign affairs stress Washington's assertiveness, while congressional primacists stress his deference. ${ }^{504}$ We think the two faces of Washington are reconcilable in a way consistent with our theory of foreign affairs power. As discussed above, the areas in which Washington acted unilaterally-ambassadors, diplomacy, foreign policy - are part of the unallocated residual power over

504. Compare Gerhard Casper, An Essay in Separation of Powers: Some Early Versions and Practices, 30 WM. \& MARY L. REV. 211, 242-60 (1989) (stressing coopcrative foreign policy), with Powell, supra note 8 (stressing Washington's unilateral acts). 
foreign affairs. As described below, the areas in which Washington acted deferentially concern matters that are granted to other branches by the text of the Constitution or that were never part of the traditional executive foreign affairs power.

One area in which Washington exercised deference to Congress was war powers. War was one of the principal executive powers of foreign affairs in the taxonomy of the great eighteenth-century writers. ${ }^{505}$ The Constitution, however, vests Congress with the power "to declare war and issue letters of marque and reprisal." ${ }^{506}$ We do not propose to enter into a substantial examination of Congress's war power. ${ }^{507}$ It is sufficient to note that this Clause appears to grant Congress some material power over war, and that Washington and his advisers saw much less room to pursue a unilateral executive program to involve the United States in war. We have already noted, for example, that in connection with the Nootka Sound incident, even the most pro-executive members of Washington's cabinetHamilton and Knox-thought it necessary to convene Congress in case war with Britain became imminent, although the entire cabinet believed that Washington could act unilaterally up to that point ${ }^{508}$ Relatedly, Hamilton's Pacificus, while arguing for broad presidential powers over foreign affairs, acknowledged an exclusive power in Congress to move the nation from peace to war. ${ }^{509}$

Further evidence of the Washington Administration's caution and deference to Congress in matters of war is found in the dispute with Algiers. A piratical state on Africa's north coast, Algiers had attacked U.S. ships and seized U.S. mariners as hostages to be ransomed. As Professor Casper recounts, Washington closely consulted Congress in deciding how to respond, as he recognized that the Algiers problem could be resolved only by money (paying the ransom) or force, both of which lay under

505. LOCKE, supra note 139, at 411; MONTESQUIEU, supra note 149, at 185; BLACKSTONE, supra note 155 , at $* 250$; RUTHERFORTH, supra note 164 , bk. II, ch. III, at 54-61; DE LOLME, supra note 168 , at $49-50$.

506. U.S. CONST. art. I, $\$ 8$.

507. Several commentators have addressed this topic. See, e.g., FiSHER, supra note 4, at 1-29 (expressing a broad view of congressional war power under the original understanding); LOFGREN, supra note 171, at 699-702 (same); Yoo, supra note 3 (expressing a limited view of congressional war power under the original understanding).

508. SOFAER, supra note 280, at 101-03; see supra Subsection VII.E.4.

509. Citing the Declare War Clause, Hamilton said "therefore, the Legislature can alone declare war, can alone actually transfer the nation from a state of peace to a state of hostility" and continued: "In this distribution of authority, the wisdom of our Constitution is manifested. It is the province and duty of the executive to preserve to the nation the blessings of peace. The Legislature alone can interrupt them by placing the nation in a state of war." HAMILTON, supra note 113 , at 443 . 
Congress's control. ${ }^{510}$ Jefferson said in his 1790 report on the matter, after laying out the alternatives:

Upon the whole, it rests with Congress to decide between war, tribute, and ransom, as the means of reestablishing our Mediterranean commerce. If war, they will consider how far our own resources shall be called forth, and how far they will enable the Executive to engage, in the forms of the constitution, the cooperation of other Powers. If tribute or ransom, it will rest with them to limit and provide the amount; and with the Executive, observing the same constitutional forms, to make arrangements for employing it to the best advantage. ${ }^{511}$

The contrast between Washington's close consultations with Congress in the Algiers matter and his willingness to act unilaterally with respect to the direction and recall of diplomats, the interaction with Genet, the Nootka Sound incident, and the Neutrality Crisis is noteworthy. We think there is an important constitutional distinction that Washington and his cabinet recognized: In the latter cases, there was room for informal diplomatic measures short of war-which fell within the President's executive power-whereas with respect to Algiers the question was simply whether to pay, fight, or do nothing. In other words, because the President's residual powers were of little use during the Algiers situation, Washington did not take unilateral measures as he had in other circumstances.

Similarly, Washington pursued a cautious and cooperative policy with respect to the hostilities along the western frontier, generally limiting himself to defensive measures unless Congress agreed to go further. ${ }^{512}$ To be sure, this no doubt arose partly out of necessity, as the United States lacked a substantial standing army, and military expeditions had to be raised and financed individually. ${ }^{513}$ But Washington also emphasized his constitutional limitations. "The Constitution," he wrote, "vests the power of declaring war with Congress; therefore, no offensive expedition of importance can be undertaken until after they have deliberated upon the subject, and authorized such a measure." ${ }^{14}$ Secretary of War Knox wrote of

510. See Casper, supra note 504. For a historian's account, see RAY W. IRWIN, THE DiPlomatic RElations of THE UNITED STATES WITH THE BARBARY POWERS 1776-1816 (1931).

511. Thomas Jefferson, Mediterranean Trade (Dec. 28, 1790), in 1 AMERICAN STATE PAPERS, FOREIGN RELATIONS, supra note 357, at 104, 105. Jefferson seemed to prefer force; Congress preferred payment, but delayed in approving sufficient money. The matter was resolved by a treaty, signed in 1795 and approved by the Senate the following year, that in effect provided for release of the hostages in return for payment of money. See Casper, supra note 504, at 242-60.

512. SOFAER, supra note 280, at 119-27.

513. Id.

514. FISHER, supra note 4, at 15 (internal quotation marks omitted). For discussions of other related writings and their context, see $i d$. at 13-16. 
Washington's view of the southern frontier, "'[w]hatever may be his impression relatively to the proper steps to be adopted, he does not conceive himself authorized to direct offensive operation.... If such measures are to be pursued they must result from the decisions of Congress who solely are vested with the powers of War." 515 Again, Washington showed his deferential side, instead of asserting his executive power as he did in other foreign affairs matters. As before, we think this shows, not a contradiction in Washington's approach, but an understanding that his executive power was residual-that is, encompassing only executive powers over foreign affairs not assigned elsewhere by the Constitution.

A second area where the President ceded the lead to Congress involved the regulation of foreign commerce. Arguably, some regulations of foreign commerce fall within the traditional executive power in the English system. ${ }^{516}$ The English monarch had the power, for example, to impose embargoes under certain circumstances. ${ }^{517}$ However, regulation of commerce with foreign nations-including embargoes-was encompassed by Congress's express Article I, Section 8 power ${ }^{518}$ Not surprisingly, there was no discussion of the President imposing an embargo (or other regulation of commerce) during the Washington Administration; these matters were handled in Congress. ${ }^{519}$ In particular, Congress obviously thought the President lacked the ability to impose an embargo on his own authority, for in 1794 it delegated to the President the power to impose an embargo during the legislative recess "whenever, in his opinion, the public safety shall so require." ${ }^{520}$ This further confirms the general understanding that foreign affairs powers conveyed to Congress by the Constitution were conveyed away from the President, even where these powers had previously been traditional executive powers.

Finally, practice in the Washington Administration confirms that the President lacked authority over matters that were traditionally legislativenotably lawmaking and appropriations-even where these powers implicated foreign affairs. Rather, these remained independent powers of Congress. ${ }^{521}$ We have discussed in some detail the efforts to enforce neutrality in 1793-1794, emphasizing the fact that the President did not

515. Id. at 15 (quoting Letter from Henry Knox to William Blount (1792)). A year later, Washington reported in his annual message to Congress of 1793 that he had prohibited offensive actions against the hostile tribes during Congress's recess, and noted that "it is with Congress to pronounce what shall be done" with respect to actions on the southwestern frontier. 4 ANNALS OF CONG. 13 (1793).

516. See 10 William Holdsworth, A History of ENGLish LaW 365 (1938).

517. Id.

518. U.S. CONST. art. $1, \S 8$.

519. See CURRIE, supra note 280 , at 55-60, 186-88 (discussing congressional activities with respect to embargoes and regulations of foreign commerce).

520. Act of June 4, 1794, ch. 41, I Stat. 372.

521. Subject, of course, to a presidential veto. 
claim that his Neutrality Proclamation had any legal force of its own right, and that his search for other legal bases upon which to enforce neutrality was largely unsuccessful. ${ }^{522}$ It is also worth noting that, although Congress raised no objections to the Neutrality Proclamation and ultimately passed the Neutrality Act to give it legislative force, Congress did not feel obligated to follow the President's lead in this matter. Instead, it debated the substance of the Act extensively, and passed it over some serious opposition. ${ }^{523}$ It was not suggested that the Proclamation bound Congress to act $^{524}$ - to the contrary, Congress plainly believed it could and should act independently in foreign affairs legislation.

Relatedly, Congress did not feel bound to follow the President's lead in foreign affairs appropriations, nor did the President expect it. For example, during the Neutrality Crisis, Washington officially told both British and French representatives that he thought the United States was obligated to compensate certain victims of privateers violating U.S. neutrality. ${ }^{525}$ When the issue came before Congress, however, that body felt no obligation to provide any compensation, despite the President's prior remarks, and declined to do so. ${ }^{526}$ Although this amounted to a potentially serious embarrassment to the President, Washington acknowledged Congress's right to act independently on the matter. ${ }^{527}$

\section{Derivative Powers of Congress}

Events of the late eighteenth century also confirm an understanding that Congress had a derivative power to legislate in support of presidential powers over foreign affairs. Consider, for example, the issuance of passports. No federal statute conveyed to the President a general authority to issue passports during Washington's administration (or indeed at any time prior to 1856). ${ }^{528}$ Although passport power does not seem to be granted

522. See supra Section VII.F.

523. CURRIE, supra note 280 , at 182 \& n.62.

524. The furthest anyone went was Hamilton, who claimed that the Proclamation bound Congress as to the meaning of the French treaties, and even this view was not widely held. See supra Subsection VII.E.3.

525. Specifically, Washington thought compensation should be given to victims of privateers to the extent that privateers continued to operate out of U.S. ports after the U.S. government had received news of the war and had time to prevent the privateering. See THOMAS, supra note 416, at 197.

526. Id. at 200.

527. Id. Hamilton argued to the contrary, although more as a matter of international law than constitutional law; but Washington specifically disavowed Hamilton's view on constitutional grounds. See Letter from George Washington to Alexander Hamilton (July 2, 1794), in 33 THE WRITINGS OF GEORGE WASHINGTON, supra note 281 , at 420,422 . On this incident in general, see THOMAS, supra note 416, at 197-200; and Stein, supra note 3, at 473-74.

528. See PASSPORT OFFICE, supra note 63 , at 30-31 (discussing the $1856 \mathrm{Act}$ ). The principal inducement to a federal act appears to have been a desire to end the practice of state governments issuing passports. $I d$. Congress at times passed laws addressing specific kinds of passports. For 
by anything in Article II, Sections 2 and 3, the Washington Administration issued passports without anyone raising any question as to its constitutional authority to do so. ${ }^{529}$ This further confirms our theory of residual executive power over foreign affairs, as the passport power would easily be encompassed by the residual power, and we think it likely that this is how the Washington Administration and its contemporaries understood it.

Although Congress did not give general passport authority to the President, it did legislate in support of the President's independent passport power. Specifically, in 1790 Congress passed a statute that, among other things, provided penalties for forgery of a U.S. passport. ${ }^{300}$ This sequence of events fits perfectly with our understanding of the respective roles of Congress and the President in foreign affairs. Although issuance of passports was an executive function, the President alone could not decree criminal penalties for forgery of a passport, since the President lacked lawmaking authority ${ }^{531}$ Congress, however, could do that, even though it lacked an enumerated power to issue passports in the first instance, since it had the power to pass laws in support of other powers granted by the Constitution. ${ }^{532}$ As a result, the 1790 Passport Act suffered no constitutional

example, in 1796 Congress by statute directed the State Department to prepare a passport form for
Mediterranean travel pursuant to the recent treaty with Algiers. Id. at 14 .
529 . See id. at 17 (reproducing a passport issued by Secretary of State Jefferson in 1793); at 38-39 (reproducing passports issued by U.S. consular officials in 1795); 17 (reproducing a passport issued by Secretary of State Jefferson 1793); id. Thomas Jefferson to James Monroe (June 28.S. consular officials in 1795); see also Letter from supra note 207, at 321,323 (1895) (discussing the in 6 THE WRITINGS OF THOMAS JEFFERSON, give U.S. passports to foreign-manufactured ships); Letter from Thomas Jefferson 1793 decision by the President to Hamilton (May 8, 1793), in 6 THE WRITINGS OF THOMAS JeFFERSON, Jefferson to Alexander 246-47 (1895) (discussing the decision of the President anferens, supra note 207, at 246, passports to French ships).

530. PASSPORT OFFICE, supra note 63, at 14. Passage of this act confirms that Congress thought the President's passport power arose directly from the Constitution, otherwise it would have used this opportunity to create a presidential passport power instead of merely reinforcing
the President's preexisting power.

531. Washington's use of passports should not be read to stand for too much, and indeed it confirms our view of the executive's lack of lawmaking power. In eighteenth-century usage, passports did not carry the domestic law connotations they do today. In particular, a passport was not required to travel abroad or to enter the United States. Rather, passports had two distinct
functions. First, when granted to U S citizens, the citizen, and requested foreign powers to accord the bearer stated that the bearer was a U.S. was, in short, an instrument of diplomacy, not of law. Second, when courtesy as a U.S. citizen. It purported to assure safe passage when not of law. Second, when granted to a foreign citizen, it ("A citizen's request for a U.S. passport actually constituted a requed in the United States. Id. at 9 Government to facilitate and safeguard the citizen's private request for a service from the necessary, be accomplished without Govemment aid.") To the undertaking, which could, if conduct needed legal sanctions legislative action was necessary, for here (and not elsewhere) exccutive passports a legislative imprimatur. not elsewhere) Congress in the 1790 Act gave within our understanding of the President as policymaker and diplomatic a ports fits comfortably lawmaker, in foreign affairs.

532. U.S. CONST. art. I, $\$ 8, \mathrm{cl}$. 18. The other key part of the 1790 Act-punishment for
vitation of a safe conduct-likely fell within Cong violation of a safe conduct-likely fell within Congress's power to punish offenses against the 
A similar event occurred shortly after the close of the Washington Administration, which we find worthy of mention. During the Adams Administration, in the course of the hostilities between the United States and France, a private U.S. citizen, George Logan, on his own initiative went to France to try to negotiate a resolution. ${ }^{534}$ Fearing interference with U.S. diplomacy from such missions, Congress enacted a law prohibiting, in effect, private diplomacy. Specifically, the Logan Act prohibited U.S. citizens from corresponding with a foreign government in an attempt either to influence the measures of a foreign government or to defeat the measures of the U.S. government. ${ }^{535}$ The Act also prohibited any person in the United States from assisting in such correspondence and thus covered foreign diplomats that might aid U.S. citizens in conducting a private intercourse with foreign nations. ${ }^{536}$

Like the 1790 Passport Act, the Logan Act is very difficult to place within Congress's specific enumerated powers. However, no one suggested that Congress might lack power to enact it, and the reason seems evident. Diplomacy is a residual executive power, and the Logan Act is a law necessary and proper to protect that power. The context of the law makes clear that this is how Congress viewed the Act, and explains why there was no question of its constitutionality. Indeed, in introducing the legislation one representative said that it criminalized actions threatening "the destruction of the Executive power of the Government." ${ }^{337}$ In short, it has long been understood that Congress has a power to legislate in support of

law of nations. However, it does not seem that the forgery prohibition would fit comfortably within that power.

533. No one defended the Passport Act on this ground, but no one objected to it, and it is decidedly difficult to find another constitutional power supporting it. The context of the legislation plainly shows that it was seen as a measure to support the executive's policy. The argument in the text would also sustain the constitutionality of the provisions of the 1856 Passport Act, denying states the ability to issue passports; that provision also seems difficult to justify under Congress's powers.

534. See DE CONDE, supra note 409, at 155-56; Frederick B. Tolles, Unofficial Ambassador: George Logan's Mission to France, 1798, 7 WM. \& MARY Q. 4 (1950).

535. Logan Act, ch. 1, l Stat. 613 (1799).

536. By its terms, the Act applied to all U.S. citizens and thus probably covered members of Congress. See Detlev F. Vagts, The Logan Act: Paper Tiger or Sleeping Giant?, 60 AM. J. INT'L L. 268, 275 (1966) (listing possible violations by members of Congress in the early twentieth century). To be sure, members of Congress would enjoy the protection of the Speech and Debate Clause while on the floor of their chambers. U.S. CONST. art. I, § 6, cl. 1.

537. 9 ANNALS OF CONG. 2488-89 (1798) (statement of Roger Griswold); see also 9 id. at 2494 (1798) (statement of Roger Griswold) (claiming that communications with foreign nations was an executive power and that if citizens could do this, they might as well act as their own legislators and judges as well). But see Vagts, supra note 536, at $293 \mathrm{n} .114$ (asserting that the Act arose out of Congress's power to define crimes against the law of nations and citing a British parliamentary debate from 1853 in support). We are not sure why the law of nations would be concerned with who speaks on behalf of a nation, and thus we are unsure how it is that Congress could rely on this enumerated power to codify the law of nations to justify the Logan Act. 
the President's residual foreign affairs powers in areas where Congress does not have an independent enumerated power. ${ }^{538}$

\section{The Senate's Unique Role}

The Senate occupied a unique constitutional position. It obviously had a share in the foreign affairs powers granted to Congress, such as declaring war and granting letters of marque and reprisal. Moreover, by virtue of its powers to confirm ambassadors and to participate in treaty-making, the Senate played a larger foreign affairs role than the House. At the same time, it was not an equal executive partner of the President. The Senate had no claim over the residual executive power wielded by the President because, as Jefferson noted, exceptions to the President's executive power were to be construed strictly. As was clear to most, confirming ambassadors and consenting to treaties hardly connoted a wide-ranging Senate authority over the nation's foreign affairs.

In practice, the Senate actually played a much larger role in treatymaking during the early years of the Washington Administration than it does today. Yet nothing in that history calls into question our claims. However broad the Senate's treaty-making role during the Washington Administration, the Senate was never regarded as the nation's "co-Chief Executive" in foreign affairs. Indeed, we have recounted numerous instances where Washington made executive decisions without any Senate role. Consistent with the Constitution's text, the Senate was but a partial executive, acting as a narrow executive council of the type found in some states. $^{539}$

538. Another probable example of this way of thinking is the Neutrality Act, discussed supra Section VII.E. This Act has been explained as an exercise of Congress's power to define and punish offenses against the law of nations. See CURRIE, supra note 280. It secms likely, however, that many of its provisions went beyond anything required by the law of nations at the time. The Neutrality Act is perhaps better understood as a law carrying into execution the President's residual power to set foreign policy (in this case, to declare neutrality). Again, the context makes it very likely that this is how Congress viewed the Act. As discussed, Washington declared U.S. policy but had difficulty enforcing it, and so he asked Congress to pass legislation in support.

539. This discussion of the Senate's role does not consider two substantial foreign affairs controversies of the Washington Administration. The first is the extent to which the requirement of the Senate's "advice and consent" to treaties requires advance consultation with the Senate before the President signs a treaty. Washington's practice varied from an early stage in which he actually met with the Senate in person (with unsatisfactory results) to later years in which his emissary, John Jay, negotiated the 1794 Treaty with England without any prior input from the Senate as a whole. See ELKINS \& MCKITRICK, supra note 280, at 55-58. The second issue, also raised by the Jay Treaty, is the extent to which the House is constitutionally obligated to provide implementing legislation or appropriations needed to give effect to a treaty. The House ultimately approved the measures called for by the Jay Treaty, but only after extended debates on its constitutional role. See id. at 441-49.

We have not discussed these matters in detail, notwithstanding their importance, because they do not directly implicate the residual executive power over foreign affairs. The latter issue concerns the relative power of the House and Senate, and the effect of the Treaty Clause of Article 


\section{H. Postscript to the Washington Administration}

Washington hardly wielded plenary power over the nation's foreign affairs. After all, the Constitution had not established an American version of the English monarch. But at the same time, no one who has closely examined Washington's control of foreign affairs can possibly believe that Washington wielded only those specific powers found in Article II, Sections 2 and 3. Washington exercised many foreign affairs prerogatives that went well beyond those narrow authorities. Advocates of legislative primacy have to believe that Washington, one of the most conscientious and principled chief executives the nation has ever had, ${ }^{540}$ violated the Constitution almost from day one. We think that an unlikely course for America's Cincinnatus. They also have to imagine that while Washington was usurping legislative prerogatives, Congress stayed quietly on the sidelines. Given Congress's assertiveness in other matters, we believe that claim to be implausible. ${ }^{541}$

Advocates of the view that the foreign affairs Constitution is incomplete have similar difficulties. While Washington repeatedly asserted and acted on his residual executive power, no one ever insisted that he had assumed powers that the Constitution had left up for grabs. Indeed, we are unaware of any politician or judge who, post-ratification, complained that the Constitution was woefully inadequate when it came to foreign affairs.

The Washington years even pose problems for proponents of a nontextual presidential primacy. Contrary to the claims of most such scholars, numerous prominent figures identified the executive power as Washington's source of foreign affairs power. Rather than making arguments about constitutional structure or highly contestable functionalist claims, Washington, Jay, Jefferson, Hamilton, Madison, and others cited the President's executive power to defend or explain Washington's foreign affairs actions. ${ }^{542}$ Moreover, there were clear limitations on the President's executive power. Neither Washington nor his advisers claimed that the President could make domestic law or direct appropriations by virtue of the residual executive power. ${ }^{543}$ Although the Washington Administration occasionally may have gone too far (as when it tried to prosecute alleged violations of the uncodified law of nations), in many respects it better

VI of the Constitution. The former issue, although a question of presidential power, in our view tums on the scope of the specific powers allocated by Article II, Section 2, and not upon the residual executive power.

540. See CURRIE, supra note 280, at 297-98 (confirming this vicw of Washington).

541. See ELKINS \& MCKITRICK, supra note 280, at 136-61, 444-49, 485-86 (discussing Congress's deep and vocal divisions over, for example, the national debt, the Jay Treaty, and the Democratic-Republican Societies).

542. See supra Section VII.B.

543. See supra Subsection VII.G.1. 
reflects constitutional limits on presidential power than do many of the more modern and extreme versions of presidential primacy in foreign affairs.

\section{CONCLUSION}

Our research continues the long overdue process of reviving the historical understanding of Article II, Section 1. Reading Article II's Vesting Clause as if it read like Article I's ignores the Constitution's text. This misinterpretation also repudiates the definitions supplied by Locke, Montesquicu, and Blackstone, and the established usage prior to the Constitution's drafting. Although the executive power essentially meant the power to execute the law, we have demonstrated that the phrase also had a secondary, foreign affairs meaning. The power to represent the nation and its citizens in the international arena was a potent part of the executive power.

Our survey also reveals that Gerhard Casper was wrong when he claimed that no one during the Washington Administration asserted that the President exercised Locke's "federative power." 544 While no one may have employed the phrase "federative power," that was only true because it was out-of-date Lockean lingo. Well-known figures-Washington, Jay, Jefferson, Hamilton, and even Madison-used "executive power" or "executive authority" as shorthand for foreign affairs authority. And each of these Framers understood that the executive power was the President's, subject of course to the Constitution's many conspicuous exceptions.

Finally, we have also identified three hitherto poorly understood limits on presidential and congressional power. First, under the Constitution, the President only has residual foreign affairs powers. When the Constitution assigns a foreign affairs power to Congress, that allocation is an exception to the President's executive power. Hence the President cannot declare war, regulate foreign commerce, and so forth. Second, the President cannot make law as a means of implementing his executive power. Although the President can set and announce the foreign policy of the federal government, the President cannot invoke the force of law against individuals outside the government who act contrary to presidential policies. To enforce the President's foreign policy within the domestic legal system, the President must secure the assistance of Congress (or two-thirds of the Senate). Last, Congress lacks a comprehensive power to legislate in foreign affairs. Outside its specific foreign affairs powers such as declaring war or regulating commerce, and laws necessary and proper to such powers, Congress may legislate only to carry into execution the President's

544. CASPER, supra note 3, at 68 . 
foreign affairs powers. Just as the President lacks the general legislative power, so too does Congress lack the residual executive power.

We mean to drag the constitutional foreign affairs debate back to the text, where constitutional debates ought to begin (if not end). Our Article propounds a particular textual theory that finds in the Constitution a complete division and allocation of foreign affairs authority. Contrary to Professor Henkin, we believe that the Constitution actually furnishes sufficient "bricks" with which to construct "all the foreign affairs powers of the federal government." ${ }^{545}$ One must simply know where the bricks are and what function they serve. If our research inspires others to return to first principles and propose textual theories of their own (complete with their own sets of bricks), we will have succeeded. Let the debate about the textual allocation of the executive power over foreign affairs begin.

545. HENKIN, supra note 5, at 15. 